UNIVERSIDADE DE SÃO PAULO

ESCOLA DE ENGENHARIA DE SÃO CARLOS

DEPARTAMENTO DE GEOTECNIA

LIZANDRA NOGAMI

INVESTIGAÇÃO DA INFLUÊNCIA DAS CARACTERÍSTICAS PETROGRÁFICAS E DA RUGOSIDADE DE PLACAS DE "GRANITOS

E MARMORE" FIXADAS COM ARGAMASSAS

ORIENTADOR: PROF.DR. ANTENOR BRAGA PARAGUASSÚ

SÃO CARLOS - SP

2013 
UNIVERSIDADE DE SÃO PAULO

ESCOLA DE ENGENHARIA DE SÃO CARLOS

DEPARTAMENTO DE GEOTECNIA

\section{INVESTIGAÇÃO DA INFLUÊNCIA DAS CARACTERÍSTICAS PETROGRÁFICAS E DA RUGOSIDADE DE PLACAS DE "GRANITOS E MARMORE” FIXADAS COM ARGAMASSAS}

Tese apresentada à Escola de Engenharia de São Carlos da Universidade de São Paulo, como parte dos requisitos para obtenção do Título de Doutor em Ciências, Programa de Pós Graduação em Geotecnia.

ORIENTADOR: PROF.DR. ANTENOR BRAGA PARAGUASSÚ

SÃO CARLOS - SP 
AUTORIZO A REPRODUÇÃO E DIVULGAÇÃO TOTAL OU PARCIAL DESTE TRABALHO, POR QUALQUER MEIO CONVENCIONAL OU ELETRÓNICO, PARA FINS DE ESTUDO E PESQUISA, DESDE QUE CITADA A FONTE.

Ficha catalográfica preparada pela Seção de Tratamento da Informação do Serviço de Biblioteca - EESC/USP

Nogami, Lizandra.

N774i Investigação da influência das características petrográficas e da rugosidade de placas de "granitos e mármore" fixadas com argamassas. / Lizandra Nogami ; orientador Antenor Braga Paraguassú. São Carlos, 2012.

Tese - Doutorado (Programa de Pós-Graduação em Geotecnia)-- Escola de Engenharia de São Carlos da Universidade de São Paulo, 2012.

1. Rochas Ornamentais. 2. Argamassa colante. 3. Cimento. I. Título. 
FOLHA DE JULGAMENTO

Candidata: Engenheira LIZANDRA NOGAMI.

Título da Tese: "Investigação da influência das características petrográficas e da rugosidade de placas de "granitos e mármore" fixadas com argamassas".

Data da defesa: $21 / 02 / 2013$

Comissão Julgadora:

Resultado:

Prof. Titular Antenor Braga Paraguassu (Orientador)

(Escola de Engenharia de São Carlos/EESC)

Prof. Titular José Eduardo Rodrigues

(Escola de Engenharia de São Carlos/EESC)

Prof. Dr. Rogerio Pinto Ribeiro

(Escola de Engenharia de São Carlos/EESC)

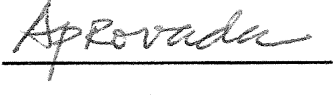

Prof. Titular Eduvaldo Paulo Sichieri

Aprovacle

(Instituto de Arquitetura e Urbanismo/USP)

Prof. Dr. Antonio Carlos Artur

Aprosada

(Universidade Estadual Paulista "Júlio de Mesquita Filho"/UNESP - Rio Claro)

Coordenador do Programa de Pós-Graduação em Geotecnia:

Prof. Titular Osni José Pejon

Presidente da Comissão de Pós-Graduação:

Prof. Titular Denis Vinicius Coury 
Aos meus pais Masaru e Kazue, irmãos Rossana e Gustavo, sobrinha Yasmin e sobrinho Augusto com amor e gratidão pelo carinho e apoio ao longo deste trabalho. 


\section{AGRADECIMENTOS}

À Deus sobre todas as coisas.

Aos meus pais Masaru e Kazue, irmãos Rossana e Gustavo, sobrinha Yasmin e sobrinho Augusto pelo carinho e apoio ao longo deste trabalho.

Ao orientador Prof. Dr. Antenor Braga Paraguassú, pela amizade, orientação e dedicação ao longo da elaboração desta tese.

Aos Professores Dr. José Eduardo Rodrigues, Dr. Eduvaldo P. Sichieri e Rogério Pinto Ribeiro e ao Dr. Ely Borges Frazão, por toda ajuda, estímulo, sugestões e avaliações no decorrer de toda a pesquisa.

Ao Prof. Antônio Carlos Artur pelas análises concedidas.

Ao Conselho Nacional de Desenvolvimento Científico e Tecnológico, pela bolsa de doutorado concedida como suporte financeiro que possibilitou a realização desta pesquisa.

À Quimicryl S.A. pela doação de material para o desenvolvimento da pesquisa.

Ao Departamento de Geotecnia da Escola de Engenharia de São Carlos e ao Instituto de Arquitetura e Urbanismo/USP São Carlos, pela infra-estrutura oferecida.

Ao colega Sérgio Trajano pelas sugestões feitas durante o desenvolvimento da pesquisa.

Aos professores do Departamento de Geotecnia que contribuíram para meu aperfeiçoamento profissional.

Aos funcionários, Álvaro Luis Nery, Antonio Claret Carriel, Antonio Garcia, Benedito Oswaldo de Souza, Décio Aparecido Lourenço, Herivelto Moreira dos Santos, Maristela A. Z. Batissaco, Neiva Mompean Rosalis Cardoso, Paulo Wanderley Prata Viera, Paulo César Albertini e Sérgio Aparecido Trevelin, do Departamento de Geotecnia da ESSC/USP e Laboratório de Construção Civil do IAU/USP que, direta ou indiretamente, contribuíram para a realização deste trabalho.

Aos amigos que fiz ao longo deste tempo, em especial à Márcia, Damares, Carla, Cleojosí e Juliana que foram embora de São Carlos deixando saudades e a Nathalia, Paola, Fernanda, July, Eliana e Karyn que nesses últimos anos estiveram ao meu lado nas horas mais difíceis e a todas as pessoas que de alguma forma contribuíram para que esta pesquisa fosse concluída. Em especial ao meu namorado Matheus que nos últimos meses me apoiou nos momentos bons e ruins. 
"Tenha coragem. Vá em frente.

Determinação, coragem e autoconfiança são fatores decisivos para o sucesso. Não importam quais sejam os obstáculos e as dificuldades. Se estamos possuídos de uma inabalável determinação, conseguiremos superá-los independentemente das circunstâncias, devemos ser sempre humildes, recatados e despidos de orgulho."

Dalai Lama 


\section{SUMÁRIO}

1 - INTRODUÇÃO

.1

2 - OBJETIVO

3 - REVISÃO DA LITERATURA .4

3.1. EVOLUÇÃO HISTÓRICA DO USO DAS ROCHAS ORNAMENTAIS 4

3.2. CARACTERÍSTICAS ECONÔMICAS DA INDÚSTRIA DA PEDRA. .5

3.2.1. Exportações Brasileiras. 7

3.2.2. Importações. .8

3.3. TECNOLOGIA DE BENEFICIAMENTO PRIMÁRIO. 8

3.3.1. Serragem de blocos e a rugosidade decorrente. 9

3.3.2. Equipamentos para determinação da rugosidade de superfícies .9

3.4. GRANITOS 10

3.5. MÁRMORE 10

3.6. CARACTERIZAÇÃO TECNOLÓGICA DE ROCHAS

3.6.1. Características Petrográficas.

3.6.2. Propriedades Físicas. 12 3.6.2.1. Índices Físicos. 
3.6.2.2. Coeficiente de Dilatação Térmica Linear

3.6.3. Propriedades "MECÂNICAS",

3.6.3.1. Resistência ao Desgaste Abrasivo (Amsler)..... .12

3.6.3.2. Resistência ao Impacto De Corpo Duro. .13

3.6.3.3. Resistência à Compressão Uniaxial 13

3.6.3.4 Resistência À Tração Na Flexão. .14

3.7. TIPOS DE TÉCNICAS DE ASSENTAMENTO DE PLACAS. .14

3.8. PROBLEMAS COM A UTILIZAÇÃO DE ROCHAS COMO REVESTIMENTO. 16

3.9. ARGAMASSA COLANTE 17

3.9.1. Cimento .18

3.9.2. Superplastificante. .19

3.9.3. Efeito Da Adição De Látices Poliméricos Às Argamassas. .20

3.9.4. Sílica Ativa. .21

3.10. NORMAS - FIXAÇÃO DE PLACAS COM ARGAMASSAS COLANTES.....22

3.10.1. Determinação da resistência de aderência à tração .23

3.10.2. Determinação do tempo em aberto. .28 
3.10.3. Determinação do deslizamento 29

3.10.4. Flexibilidade 30

3.10.5. Estudo da microestrutura do conjunto substrato/argamassa/rocha.......31

4 - MATERIAIS 33

4.1. SELEÇÃO DOS TIPOS DE ROCHAS DE REVESTIMENTO E SEUS PRINCIPAIS MINERAIS. .33

4.1.1. Granitos 33

4.1.1.1. Preto São Gabriel (Hiperstênio Diorito). 34

4.1.1.2. Azul Fantástico (Monzogranito Megaporfirítico Gnaissificado). .35

4.1.1.3. Amarelo Ornamental (Granada Gnaisse Porfiroblástico). .37

4.1.1.4. Vermelho Brasília (Sienogranito). .40

4.1.1.5. Cinza Andorinha (Monzogranito). .42

4.1.1.6. Jacarandá Rosado (Migmatito Sienogranítico) .44

4.1.1.7. Preto Indiano (Migmatito com estrutura dobrada). .46

4.1.1.8. Verde Labrador (Charnockito). .49

4.1.2. Mármore. .50

4.1.3. Principais Minerais das Rochas Estudadas. .52 
4.2.2. Argamassa porcelanato.

4.2.3. Argamassas preparadas tendo como base a argamassa para porcelanato

5.2. DETERMINAÇÃO DO TEMPO EM ABERTO 59

5.3. DETERMINAÇÃO DA FLEXIBILIDADE DA ARGAMASSA

5.4. DETERMINAÇÃO DO DESLIZAMENTO. .60

5.5. ENSAIO DE RESISTÊNCIA DE ADERÊNCIA À TRAÇÃO.

5.5.1. Confecção do substrato padrão. .61

5.5.2. Preparação dos corpos de prova. .61

5.5.3. Determinação da resistência de aderência ao arrancamento por tração. 61

5.6. MICROESTRUTURA DA INTERFACE ROCHA/ARGAMASSA 62

5.7. ATAQUE QUÍMICO .62

5.8. ENSAIO DE CONGELAMENTO E DEGELO. .63

6 - RESULTADOS DOS ENSAIOS. .65 
6.1. ASPECTOS APRESENTADOS PELAS ARGAMASSAS

65

6.2. DETERMINAÇÃO DO TEMPO EM ABERTO.

.65

6.3. DETERMINAÇÃO DA FLEXIBILIDADE 66

6.4. DETERMINAÇÃO DO DESLIZAMENTO.

6.5. RESISTÊNCIA DE ADERÊNCIA

68

6.6. MICROESTRUTURA DA INTERFACE ROCHA/ARGAMASSA. .75

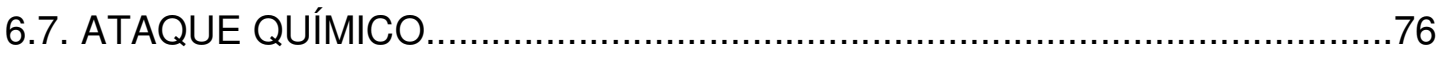

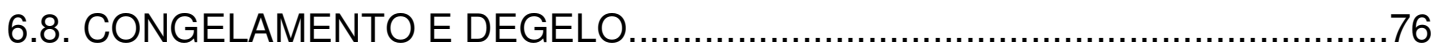

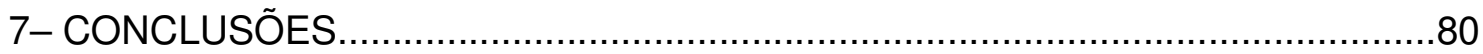

7.1. SUGESTÕES PARA TRABALHOS FUTUROS ......................................81

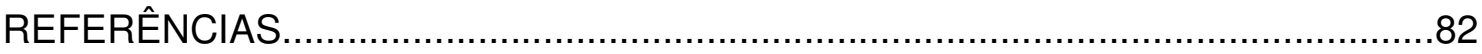


XVIII 


\section{LISTA DE FIGURAS}

Figura 3.1 - Métodos disponíveis de medição da rugosidade (GRASSELLI, 2001)..10

Figura 3.2 - Bloco esquemático de rocha movimentada (sem escala), orientado de acordo com a programação de serragem. Observar as direções de amostragem dos corpos de prova para determinação da resistência à compressão: $\mathbf{F}$ - frontal e $\mathbf{L}$ lateral (RIBEIRO, 2005)

Figura 3.3 - Bloco esquemático de uma rocha movimentada, orientado de acordo com a programação de serragem. Observar as direções de amostragem: $F$ e $S$ (RIBEIRO, 2005).

Figura 3.4 - Colocação do concreto no molde até que a tela esteja totalmente recoberta e que o concreto esteja nivelado com as cantoneiras da forma..... .25

Figura 3.5 - Adensamento em mesa vibratória 25

Figura 3.6 - Cura do substrato por 24 horas 25

Figura 3.7- Detalhe dos cordões da argamassa colante Industrializada formados pela desempenadeira.

Figura 3.8 - Equipamento utilizado no ensaio de resistência de aderência à tração. (C) componente metálico que é colado no corpo-de-prova e conectado ao equipamento; (CP) Corpo-de-prova. .27

Figura 3.9 - Ilustração das tensões ocorridas durante o ensaio de arrancamento....28

Figura 3.10 - Tensões cisalhantes .31 
Figura 4.1 - "Granito" Preto São Gabriel.

Figura 4.2 - "Granito" Azul Fantástico .36

Figura 4.3 - "Granito" Amarelo Ornamental 38

Figura 4.4 - "Granito" Vermelho Brasília 40

Figura 4.5 - "Granito" Cinza Andorinha 43

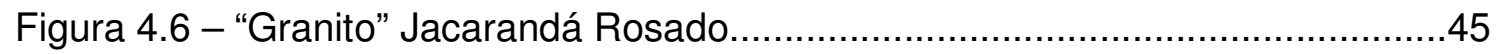

Figura 4.7- "Granito" Preto Indiano. . .47

Figura 4.8- "Granito" Verde Labrador. .49

Figura 4.9 - Mármore Carrara. 51

Figura 5.1 - Detalhe do "Avaliador de Rugosidade de Chapas - ARC", PARAGUASSÚ et. al. (2.004): (A) corpo do equipamento; (B) carro de medição; (C) defletômetro digital com precisão de $0,001 \mathrm{~mm}$.; (D) placa de rocha; $(E)$ interface que envia as medidas do defletômetro para o computador $(F)$. .56

Figura 5.2 - Definição de $\mathrm{R}_{\mathrm{t}}$ (SANDVIK, 1994 apud SPÍNOLA, 1998)..... .57

Figura 5.3 - Preparação dos corpos-de-prova de quartzo. .57

Figura 5.4 - Preparação dos corpos-de-prova (corpo-de-prova desenhado em verde) do microclinio. .58

Figura 5.5 - Preparação dos corpos-de-prova do feldspato microclinio, corpo-deprova pronto .58 
Figura 5.6 - Preparação dos corpos-de-prova da calcita, corpo-de-prova pronto.....58

Figura 5.7 - Rugosímetro de contato modelo Talysurf 1205 59

Figura 5.8 - Definição de $\mathrm{R}_{\mathrm{a}}$ (SANDVIK, 1994 apud SPÍNOLA, 1998) .59

Figura 6.1 - Resistência de aderência com corpos-de-prova fixados depois de $30 \mathrm{~s}$, $10 \mathrm{~min}, 15 \mathrm{~min}, 20 \mathrm{~min}, 25 \mathrm{~min}, 30 \mathrm{~min}$ para as argamassas para porcelanato, Arg1, Arg2 e Arg3. 65

Figura 6.2 - Deformação transversal das argamassas..........................................66

Figura 6.3 - Resistência à flexão das argamassas...............................................66

Figura 6.4 - Fator $\mathbf{F}$ resultante do produto entre a força e deslocamento transversal 67

Figura 6.5 - Resistência de aderência para cada argamassa com todas as rochas estudadas 69

Figura 6.6 - Resistência de aderência para cada argamassa com todas as rochas estudadas 71

Figura 6.7 - Resistência de Aderência vs. Rugosidade para a Argamassa Industrializada. 72

Figura 6.8 - Resistência de Aderência vs. Rugosidade para a Argamassa Arg1 1.....72

Figura 6.9 - Resistência de Aderência vs. Rugosidade para a Arg2 .73

Figura 6.10 - Resistência de Aderência vs. Rugosidade para a Arg3. .73 
Figura 6.11 - Resistência de Aderência vs. Rugosidade para a argamassa para porcelanato. .73

Figura 6.12 - Resistência de Aderência vs. Rugosidade para o Mármore Carrara...74

Figura 6.13 - Conjunto Substrato Padrão/Argamassa Colante/Rocha. 75

Figura 6.14 - Rugosidade (marcada em vermelho) apresentada pela rocha na interface rocha/argamassa. 75

Figura 6.15 - Contato nítido rocha/argamassa sem borda de reação .75

Figura 6.16 - Ancoragem na interface substrato padrão/argamassa .75

Figura 6.17 - Resistência de aderência da argamassa Industrializada antes e depois do ensaio de congelamento/degelo. 77

Figura 6.18 - Resistência de aderência da Arg1 antes e depois do ensaio de congelamento/degelo. .77

Figura 6.19 - Resistência de aderência da Arg2 antes e depois do ensaio de congelamento/degelo. .78

Figura 6.20 - Resistência de aderência da Arg3 antes e depois do ensaio de congelamento/degelo. .78

Figura 6.21 - Resistência de aderência da argamassa para porcelanato antes e depois do ensaio de congelamento/degelo. . .79

Figura 6.22 - Resistência de aderência das argamassas estudadas depois do ensaio de congelamento/degelo. 


\section{LISTA DE TABELAS}

Tabela 3.1 - Normas utilizadas para avaliação das propriedades tecnológicas de rochas para revestimento

Tabela 4.1 - Composição Mineralógica do Preto São Gabriel. .35

Tabela 4.2 - Composição Mineralógica do Azul Fantástico. .37

Tabela 4.3 - Composição Mineralógica do Amarelo Ornamental.

Tabela 4.4 - Composição Mineralógica do Vermelho Brasília.

Tabela 4.5 - Composição Mineralógica do Cinza Andorinha

Tabela 4.6 - Composição Mineralógica do Jacarandá Rosado. 46

Tabela 4.7 - Composição Mineralógica do Preto Indiano - Paleossoma. .48

Tabela 4.8 - Composição Mineralógica do Preto Indiano - Leucossoma 48

Tabela 4.9 - Composição Mineralógica do Verde Labrador. .50

Tabela 4.10 - Resultados da análise química 53 
Tabela 4.11 - Resultados de reconstituição do traço .53

Tabela 4.12 - Composição granulométrica .54

Tabela 4.13 - Argamassas preparadas tendo como base a composição da argamassa para porcelanato. .55

Tabela 5.1 -Quantidade de corpos-de-prova. .62

Tabela 5.2 - Substâncias químicas e suas respectivas concentrações utilizadas no ataque químico .63

Tabela 6.1 - Resultados do ensaio de deslizamento. 68

Tabela 6.2 -Resistência de aderência média das argamassas (entre 8 corpos-deprova) para todas as rochas estudadas com a face rugosa em contato com a argamassa. 69

Tabela 6.3 -Resistência de aderência média das argamassas (entre 8 corpos-deprova) para todas as rochas estudadas com a face polida em contato com a

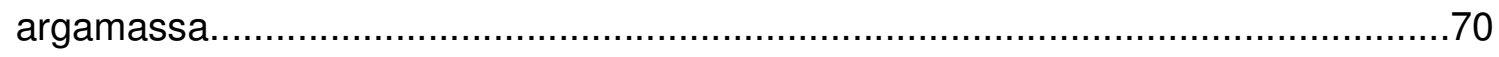

Tabela 6.4 - Aderência dos minerais............................................................75 


\section{RESUMO}

NOGAMI, L. Investigação da influência das características petrográficas e da rugosidade de placas de "granitos e mármore" fixadas com argamassa. 2012. 91 f. Tese (Doutorado) - Departamento de Geotecnia, Universidade de São Paulo, Escola de Engenharia de São Carlos, São Paulo, 2012.

No presente trabalho foram comparadas as aderências e propriedades de cinco tipos de argamassas colantes para fixar ladrilhos de "granitos e mármore" em pisos e revestimentos de edificações. Uma das argamassas é industrializada e específica para granitos e mármores, outra preparada em laboratório para fixação de porcelanatos e mais três argamassas também desenvolvidas em Laboratório, tendo como base a argamassa para porcelanato. Para a realização do ensaio de aderência foram escolhidos oito tipos diferentes de "granitos" e um mármore de grande aceitação comercial. Os resultados evidenciaram a excelente qualidade das argamassas colantes desenvolvidas em laboratório as quais superaram a industrializada. Verificou-se também que a aderência de todas as argamassas está relacionada à rugosidade das placas e às características mineralógicas dos "granitos".

Palavras-chave: Argamassa Colante, Cimento e Rochas Ornamentais. 
$X X V I$ 


\begin{abstract}
NOGAMI, L. Investigation of the influence of the petrographic characteristics and the roughness of plates "granites and marble" set with mortar. 2012. 91 p. Thesis (Doctoral) - Departamento de Geotecnia, Universidade de São Paulo, Escola de Engenharia de São Carlos, São Paulo, 2012.
\end{abstract}

In this paper, the adherence of five types of adhesive mortars used for fixing granite and marble tiles in floors and linings of buildings were compared. One of the mortars is industrialized and specific for granites and marbles, another one, is prepared in the laboratory for setting porcelains, and three other types of mortars, also developed in the laboratory, having the porcelain mortar as a base (were used). To carry out the adherence test, eight types of granites and one marble of large commercial acceptance were selected. The results of the tests showed the excellent quality of the adhesive mortars developed in the laboratory, which were considered superior than the industrialized type. Likewise, it was noted that the adherence of all types of mortars is related to the roughness of the plates and to the mineralogical characteristics of the granites.

Keywords: adhesive mortar, cement, dimension stones. 
XXVIII 


\section{1 - INTRODUÇÃO}

As rochas ornamentais e de revestimento, além de proporcionar beleza e durabilidade às edificações, inserem-se em um importante setor da economia em diversos países sendo o Brasil um dos principais exportadores mundiais. Possui o maior parque industrial de teares multifio diamantado, concentrado no Estado do Espírito Santo (CHIODI FILHO, 2013).

Muitas das operações de extração e de beneficiamento ainda são baseadas em empirismo, mesmo com o grande avanço tecnológico que vem ocorrendo no mundo. O mesmo ocorre na fixação de placas de muitos tipos de rochas atualmente comercializados, onde as relações das argamassas com o conteúdo químicomineralógico desses materiais não são bem conhecidas podendo desenvolver após o assentamento, patologias, quebras e até mesmo deslocamentos de placas.

Até pouco tempo o uso das rochas era restrito às construções luxuosas, hoje está mais difundido nas residências e registra um acréscimo considerável não só pelas suas qualidades e efeito estético, mas pelo preço que se tornou mais acessível. Isto implicou no aumento do consumo de argamassa para a fixação havendo necessidade de estudos mais detalhados sobre as suas composições para qualificá-las frente à grande variedade de tipos de rochas hoje existentes no mercado.

Neste contexto, diversos tipos de patologias podem ocorrer nas rochas, desde simples manchas que interferem apenas na estética, até mesmo fissuras, quebras e destacamentos, que causam grandes prejuízos e comprometem toda a sua funcionalidade e segurança.

Por outro lado, em revestimentos feitos com placas cerâmicas existem trabalhos científicos, normas e especificações tanto para o método de fixação como para os materiais utilizados. No entanto, quando se trata da colocação de ladrilhos de rocha com argamassas há pouca informação e faltam normas e especificações que orientem uma boa aplicação. No caso das argamassas colantes existentes no mercado, elas se restringem a um tipo específico para "mármores" e "granitos" (subtipo: ambiente interno e externo) e outro para ardósia.

A presente pesquisa é uma continuação do estudo iniciado na dissertação de mestrado (NOGAMI, 2007), onde foram obtidos resultados comparativos entre a 
argamassa específica para "granitos" e "mármores", existente no mercado, e outra para porcelanato desenvolvida por pesquisadores do Departamento de Arquitetura da Escola de Engenharia de São Carlos da Universidade de São Paulo e outras três argamassas desenvolvidas no Departamento de Geotecnia em conjunto com o Laboratório de Construção Civil ambos da Escola de Engenharia de São Carlos da Universidade de São Paulo.

A tese se inicia, após a apresentação do objetivo com uma revisão da literatura sobre a Indústria da Pedra, as características que as rochas devem satisfazer para uso em revestimentos e a composição das argamassas (CAPÍTULO 3).

O CAPÍTULO 4 trata dos tipos de rocha selecionados, seus principais minerais e as argamassas colantes utilizadas.

No CAPÍTULO 5 estão os procedimentos dos ensaios, no CAPÍTULO 6 os resultados obtidos e as conclusões são apresentadas no CAPÍTULO 7. 


\section{2 - OBJETIVO}

O objetivo da presente pesquisa é comparar uma argamassa industrializada específica para diferentes tipos de rochas comercializadas na forma de placas com outras argamassas desenvolvidas em laboratório, verificando-se a influência da rugosidade e das características mineralógicas na propriedade da resistência de aderência. 


\section{3 - REVISÃO DA LITERATURA}

As rochas ornamentais e de revestimento, também designadas rochas lapídeas, rochas dimensionais e materiais de cantaria, abrangem os tipos litológicos que podem ser extraídos em blocos ou placas, cortados em formas variadas e beneficiados através de esquadrejamento, polimento, lustro, etc.

Do ponto de vista comercial, são subdivididas basicamente em mármores e granitos, numa designação mais ampla do que os termos petrológicos tradicionais (BRANDÃO et al., 1991).

O aspecto estético é o principal condicionante para o uso das pedras de revestimento. Conjugado a este fator, devem ser consideradas as características tecnológicas da rocha, a tipologia do jazimento, bem como os possíveis defeitos decorrentes das etapas de extração e de beneficiamento (FRASCÁ \& QUITETE, 2000). Em conjunto, estas características condicionam a qualificação das rochas para os diferentes usos. FRAZÃO \& PARAGUASSU (1998) fizeram um apanhado das funções que as rochas devem ter para utilização em revestimentos verticais de exteriores e interiores e também em piso de edificações, apresentando os requisitos de qualidade para que possam apresentar bom desempenho.

O Brasil apresenta um enorme potencial geológico para mármores e, especialmente, granitos de diferentes padrões estéticos, homogêneos e movimentados. Quanto às exportações de granitos brutos, o Brasil colocou-se em quarto lugar com 9,9\%, atrás da Índia (18,2\%), África do Sul $(11,7 \%)$ e China (10,4\%), situando-se em $12^{\circ}$ lugar das exportações mundiais de rochas processadas (ABIROCHAS, 2011a).

\subsection{EVOLUÇÃO HISTÓRICA DO USO DAS ROCHAS ORNAMENTAIS}

Desde os tempos pré-históricos, as rochas têm sido utilizadas para os mais diversos fins. Elas viriam a ser usadas com função estética e ornamental ao redor de 3.000 a.C. pelos mesopotâmios e egípcios e, posteriormente, pelos gregos, que difundiram seu emprego por meio da escultura e da arquitetura. Finalmente os 
romanos consolidaram seu uso nas mais audaciosas obras públicas da antigüidade. Por volta do ano 80 a.C. eles começaram a utilizar em revestimento de grandes construções de tijolos, principalmente por motivos estéticos e para dar a estas obras um aspecto opulento e duradouro. Tornaram-se os pioneiros nesta modalidade.

Naquela época, Roma explorava o mármore travertino, em ocorrência próxima à cidade (Tivoli). Posteriormente, o centro mundial de produção se deslocou para a região de Carrara, cuja tradição na exploração subterrânea e a céu aberto do mármore perdura até os dias atuais.

A expansão comercial das rochas ornamentais e a decorrente diversificação de suas formas se deram com o processo gradual de mecanização da indústria de extração e de beneficiamento no início do século XX. Desde então, em função da combinação de suas qualidades estruturais e estéticas, elas constituem um importante produto em diversas áreas.

Atualmente, cerca de $70 \%$ da produção mundial é transformada em chapas e ladrilhos para revestimentos, $15 \%$ é desdobrada em peças para arte funerária, 10\% para obras estruturais e $5 \%$ para outros campos de aplicações. O consumo de rochas é estimado em 600 milhões de $\mathrm{m}^{2} / \mathrm{ano}$, sendo os produtos cerâmicos, com um consumo de 3,8 bilhões de $\mathrm{m}^{2} / \mathrm{ano}$, seus principais concorrentes na construção civil (ABIROCHAS, 2011a).

Esta diversidade de aplicação das rochas gera um conjunto de produtos extremamente amplo, mas que podem ser resumidos em seis tipos principais: blocos, chapas, placas para revestimentos de paredes e/ou fachadas, ladrilhos modulares, revestimento de escadas e de pisos e obras dimensionais ou manufaturados (ABIROCHAS, 2011b).

Em qualquer tipo de aplicação, o ciclo produtivo pode ser dividido em quatro etapas bem definidas: pesquisa mineral, extração de blocos, serragem em placas e acabamentos superficiais, que fazem parte do que é conhecido como "Indústria da Pedra".

\subsection{CARACTERÍSTICAS ECONÔMICAS DA INDÚSTRIA DA PEDRA}

As rochas ornamentais e de revestimento constituem uma das áreas mais promissores no setor mineral. A produção mundial de rochas para ornamentação e 
revestimento atingiu 116 milhões de toneladas em 2011, com variação positiva de $4,0 \%$ frente a 2010. No Brasil, foi um dos poucos setores da economia que apresentou um crescimento nas taxas anuais de produção (Abirochas, informe 11/2012).

Dessa produção total, 68,5 milhões $\mathrm{t}(59 \%)$ foram referentes a rochas carbonáticas (mármores, travertinos e calcários diversos), 41,7 milhões t (36\%) a rochas silicáticas e silicosas (granitos, quartzitos e similares) e 5,8 milhões $t(5 \%)$ a outras rochas, sobretudo ardósias. A produção de 116 milhões t corresponderia a 42,95 milhões $\mathrm{m}^{3}$ ou 1.265 milhões $\mathrm{m}^{2}$ equivalentes em chapas com $2 \mathrm{~cm}$ de espessura (Abirochas, informe 11/2012).

Estima-se que os negócios do setor movimentem pelo menos US $\$ 17,96$ bilhões/ano, colocando-se 49,5 milhões de toneladas em rochas brutas e processadas no mercado internacional. Cerca de $75 \%$ da produção mundial é transformada em chapas e ladrilhos para revestimentos (31,5\% para pisos / pavimentos, $8,5 \%$ para paredes / fachadas externas, (3,0\%) para degraus, $12 \%$ para paredes internas e $20 \%$ para peças e obras especiais), $5 \%$ para paisagismo, $16,5 \%$ para arte funerária e 3,5\% para outros usos e trabalhos especiais. O consumo de rochas é estimado em 1.265 milhões de $\mathrm{m}^{2} / \mathrm{ano}$, sendo os produtos cerâmicos, com um consumo de 8,75 bilhões de $\mathrm{m}^{2} / \mathrm{ano}$, seus principais concorrentes na construção civil (Abirochas, informe 11/2012).

Do ponto de vista comercial, as rochas ornamentais e de revestimento são basicamente classificadas em granitos e mármores, que perfazem cerca de $90 \%$ da produção mundial. Ardósias, quartzitos, pedra sabão, serpentinitos, basaltos, conglomerados naturais, também se destacam setorialmente.

A média dos preços internacionais para blocos de mármores e granitos, situa-se entre US\$ 400 e US\$1.200/ $\mathrm{m}^{3}$, enquanto que o preço médio do produto final varia de US\$ 30 a $60 / \mathrm{m}^{2}$. O padrão cromático é o principal atributo considerado para qualificação comercial de uma rocha (Abirochas, 2011a).

Mundialmente, a China é um dos principais "players" do setor, colocando-se entre os maiores produtores, maior importadora de matéria prima, maior consumidora per capita e maior exportadora de rochas, bens de capital e tecnologia. O Brasil colocouse como o $7^{\circ}$ maior exportador mundial, em volume físico total, e em $3^{\circ}$ lugar como 
exportador de blocos de granitos (atrás da Índia e China) e produtos de ardósia (atrás da Espanha e China) (Abirochas, informe 11/2012).

Destaca-se por fim que o Brasil ultrapassou a China no mercado dos EUA, tornando se novamente o principal fornecedor de rochas deste país, tanto em faturamento quanto em volume físico. Isto se deve as 606 mil t vendidas aos EUA em 2011, 594 mil t das quais referentes a chapas de granito. No total, a China exportou 598 mil t de rochas aos EUA em 2011 (Abirochas, informe 11/2012).

A participação brasileira no mercado internacional de rochas processadas é ainda limitada e está bastante aquém da posição da China e Índia, nossos principais concorrentes (Abirochas, 2011a).

\subsubsection{Exportações Brasileiras}

A seguir serão apresentados dados recentes colhidos pela Abirochas (informe 15/2012).

As exportações do período janeiro-novembro de 2012 atingiram US\$ 981,21 milhões e 2.080.555,60 t, mantendo variação positiva tanto em faturamento $(+6,72 \%)$, quanto em volume físico $(+3,62 \%)$, frente ao mesmo período de 2011 . As exportações do mês de novembro, especificamente, somaram US\$ 87,05 milhões e 205.216,76 t, superando as do último mês de outubro.

Destaca-se a persistência da queda das exportações de produtos de ardósia, produtos de quartzitos foliados, blocos de pedra sabão e possivelmente de chapas e outros produtos de pedra-sabão. Todas essas exportações são quase integralmente devidas ao Estado de Minas Gerais, que cada vez mais perde sua importância relativa no setor brasileiro de rochas ornamentais.

Outro destaque, desta vez positivo, é a persistência do incremento das exportações brasileiras de rochas carbonáticas, mais especificamente de mármores, ao longo de 2012, tanto para blocos, quanto para chapas.

A variação do faturamento $( \pm 6 \%$ ), frente a 2011 , poderá ser ligeiramente incrementada em 2013, pelo aquecimento do mercado de chapas nos EUA e de blocos na China, compensando a provável queda de vendas para o continente europeu. 


\subsubsection{Importações}

Segundo a Abirochas (informe 15/2012), as importações de materiais rochosos naturais somaram US\$ 55,95 milhões e $90.887,40$ t no período janeiro-novembro, com variação negativa de respectivamente $10,15 \%$ e 5,94\% frente a 2011 . Continua havendo queda do preço médio das importações brasileiras de rochas.

As importações de materiais rochosos artificiais somaram US\$ 43,81 milhões e $56.893,81$ t, com variação positiva de respectivamente $59,81 \%$ e $101,77 \%$ frente a 2011. O volume físico das importações de materiais rochosos artificiais representou $63 \%$ daquele das importações de materiais rochosos naturais, no período janeironovembro de 2012.

\subsection{TECNOLOGIAS DE BENEFICIAMENTO PRIMÁRIO}

Em geral, os blocos extraídos nas pedreiras têm volume variável entre $5 \mathrm{~m}^{3} \mathrm{e} 8 \mathrm{~m}^{3}$, podendo atingir, excepcionalmente, $12 \mathrm{~m}^{3}$. Todavia, materiais especiais com alto valor comercial permitem o aproveitamento de blocos a partir de $1 \mathrm{~m}^{3}$. Após o esquadrejamento feito na própria pedreira, ou após ter sido refilado com máquina monolâmina ou por meio do fio diamantado, o bloco é encaminhado à serraria para ser beneficiado.

A serragem de blocos realizada com teares é a mais tradicional e amplamente difundida, independentemente do material a ser processado, principalmente por conjugar elevada produtividade e maior flexibilidade produtiva (ao gerar uma ampla gama de produtos finais a partir das chapas).

Ela se dá pela ação de um elemento abrasivo (granalha de aço) conduzido por um conjunto de lâminas de aço movimentadas pelo tear que pelo corte, induz uma rugosidade nas superfícies das placas.

Essa rugosidade determina o volume de material a ser removido na face a ser polida e na outra face exerce papel importante na aderência com as argamassas de assentamento. 


\subsubsection{Serragem de blocos e a rugosidade decorrente}

A serragem de blocos de granitos realizada em teares multilâminas é a mais tradicional e amplamente difundida. É a operação mais complexa da indústria da pedra e as chapas obtidas apresentam maior ou menor rugosidade em função das características da rocha, dos insumos utilizados e das condições operacionais.

Rochas de mesma composição mineralógica mas com diferenças texturais podem necessitar de maior tempo de serragem (até 60\%) resultando em superfícies três vezes mais rugosas (Ribeiro, 2005). A rugosidade, no dia a dia das serrarias é avaliada por inspeção táctil/visual. No entanto, como é um parâmetro fundamental, para o presente trabalho, na relação com a aderência, ela foi quantificada utilizando o perfilômetro portátil, projetado e construído por PARAGUASSÚ et. al (2004), aprimorado por RIBEIRO (2005).

\subsubsection{Equipamentos para determinação da rugosidade de superfícies}

Uma maneira simples de avaliar a rugosidade de uma superfície é deslizar um dedo através da mesma. De modo similar, nos perfilômetros tradicionais um apalpador move-se ao longo de uma dada linha superficial, sendo medidos seu deslocamento e a altura da superfície relativa ao perfil. Com base neste princípio, RENGERS (1970) desenvolveu o primeiro perfilômetro para o registro mecânico de rugosidade. A partir da década de 80, o avanço tecnológico dos computadores possibilitou o desenvolvimento de sistemas mais rápidos e sofisticados.

Uma classificação dos principais métodos disponíveis atualmente para a mensuração da rugosidade é apresentada na Figura 3.1. Eles são agrupados em duas categorias principais, dependendo se eles fornecem dados bi ou tridimensionais. Os diferentes sistemas foram divididos de acordo com a proposta de GRASSELLI (2001), tendo sido abordados diversos aspectos, tais como velocidade e acuracidade do sistema, precisão e resolução das medidas e duração das mensurações e da análise dos dados. 


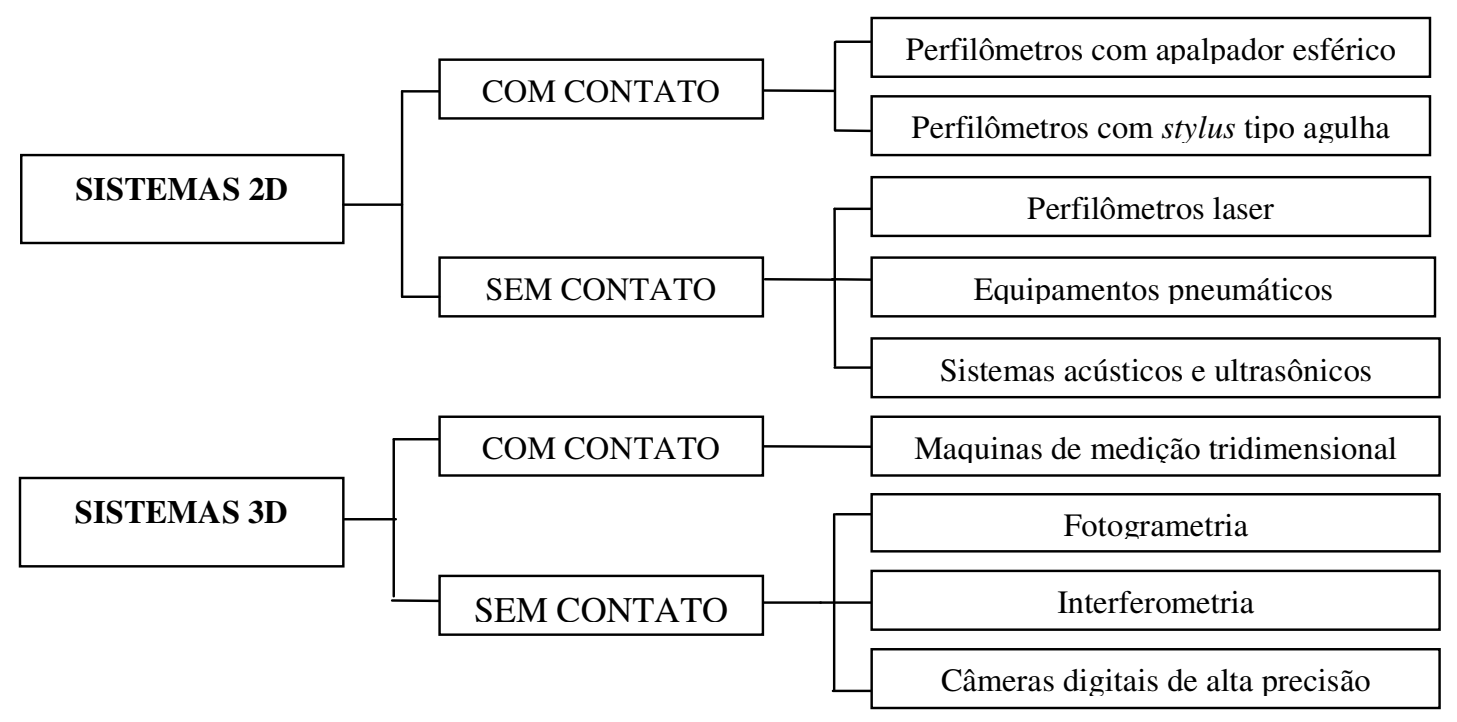

Figura 3.1 - Métodos disponíveis de medição da rugosidade (GRASSELLI, 2001).

\subsection{GRANITOS}

No estudo das rochas ornamentais e de revestimentos o termo "granito", comercialmente, engloba a família das rochas silicáticas. Os minerais constituintes são essencialmente feldspatos, quartzo, micas (biotita e muscovita), em menor porcentagem e nem sempre presentes ocorrem anfibólios (comumente a hornblenda) e piroxênios (aegirina, augita e hiperstênio ). Podem ocorrer como acessórios, pequenos cristais de ilmenita, zircão, magnetita, apatita, granada, topázio, cordierita e fluorita.

A resistência ao desgaste abrasivo das rochas é proporcional à "dureza" de seus minerais, assim nos granitos com mesmas texturas a resistência será maior quanto maior a quantidade de quartzo presente. O desgaste das rochas pode ser também provocado por escarificação (arranque) dos grãos minerais, o que parece estar condicionado não à composição mas às causas texturais.

\subsection{MÁRMORE}

O mármore é uma rocha metamórfica proveniente do calcário que pode apresentar cores variadas como rósea, branca, esverdeada ou preta. É usado em 
decorações, na confecção de objetos ornamentais, esculturas e como rochas de revestimento.

Quando comparado ao granito, o mármore é de baixa "dureza", mais corrosível a ação de ácidos e menos resistente ao tempo. Deve ser evitada a utilização de mármore em pisos, por ser um material que se desgasta mais facilmente sendo indicado para revestimento de paredes internas.

\subsection{CARACTERIZAÇÃO TECNOLÓGICA DE ROCHAS}

É feita por meio de ensaios que determinam as propriedades físicas e mecânicas e objetivam balizar os campos de aplicação dos materiais conforme padrões normatizados. Para que uma rocha seja utilizada em pisos e revestimentos é necessário que atenda algumas especificações para que o material resista às solicitações de uso. Os ensaios constam como itens obrigatórios em catálogos promocionais e são exigidos pelos grandes compradores. Na tabela 3.1 estão listados as normas utilizadas nesse trabalho para a caracterização das rochas.

Tabela 3.1 - Normas brasileiras utilizadas para avaliação demasiadamente simplificada das propriedades tecnológicas de rochas para revestimento.

\begin{tabular}{|c|c|}
\hline Propriedades & Revestimento \\
\hline Petrografia & ABNT NBR 12768 (1992) \\
\hline Índices Físicos & ABNT NBR 12766 (1992) \\
\hline Dilatação térmica & ABNT NBR 12765 (1992) \\
\hline Desgaste & ABNT NBR 12042 (1992) \\
\hline Impacto & ABNT NBR 12764 (1992) \\
\hline Compressão & ABNT NBR 12767 (1992) \\
\hline Flexão & ABNT NBR 12763 (1992) \\
\hline
\end{tabular}

\subsubsection{Características Petrográficas}

Com base nas diretrizes da Norma 12768 (ABNT, 1992a), a análise petrográfica é efetuada por meio de observação macroscópica e de microscopia óptica de luz polarizada em lâminas delgadas (espessuras na ordem de $30 \mu \mathrm{m}$ ) extraídas das rochas em três direções ortogonais, uma delas paralela à superfície serrada. 
Em granitos de granulação relativamente grossa, a porcentagem modal pode ser determinada pela integração entre contagens minerais efetuadas diretamente sobre placas polidas. Neste caso a técnica utilização é a de coloração seletiva de feldspatos, segundo a metodologia de MORAES \& RODRIGUES (1978).

\subsubsection{Propriedades Físicas}

\subsubsection{1. Índices Físicos}

Uma rocha no seu estado natural apresenta-se como um conjunto de minerais interligados ocupando um determinado tamanho, constituído pelos minerais e pelos vazios entre estes. A maior ou menor quantidade de vazios gera menor ou maior compacidade da rocha, que refletirá numa maior ou menor massa específica e por conseqüência, maior ou menor porosidade. Os índices físicos são, portanto a massa específica ou densidade, porosidade e absorção d'água.

A quantidade de água, ou liquido qualquer, capaz de preencher os poros define a capacidade da rocha em absorver e reter a água nos seus poros.

Os valores de massa específica aparente seca, porosidade aparente e absorção d'água são determinados com base na norma NBR 12766 (ABNT, 1992e).

\subsubsection{Coeficiente de Dilatação Térmica Linear}

No assentamento de placas de rocha é necessário considerar a dilatação da rocha no dimensionamento das juntas, para que não ocorra problemas como trincamento da placa ou desplacamento. Este ensaio é realizado seguindo-se as diretrizes da norma NBR 12765 (ABNT, 1992d).

\subsubsection{Propriedades "MECÂNICAS"}

\subsubsection{Resistência ao Desgaste Abrasivo (Amsler)}

É uma propriedade que qualifica a rocha para uso em pisos. De acordo com a norma NBR 12042 (ABNT, 1992a), são realizadas determinações da redução da 
espessura (em $\mathrm{mm}$ ) de corpos de prova, extraídos de placas polidas, submetidos aos percursos abrasivos de 500m e 1000m na máquina "Amsler".

\subsubsection{Resistência ao Impacto De Corpo Duro}

Assim como o desgaste "Amsler", a resistência ao impacto de corpo duro é uma propriedade de grande importância para a utilização das placas de rocha em pisos. A resistência ao impacto é determinada através da medição da altura de queda de um corpo sólido que provoca ruptura do corpo de prova.

Com base na norma NBR 12764 (ABNT, 1992c), o ensaio é feito em cinco ladrilhos $20 \times 20 \times 3 \mathrm{~cm}$ para cada tipo de rocha.

\subsubsection{Resistência à Compressão Uniaxial}

O ensaio é realizado segundo a norma NBR 12767 (ABNT, 1992f).

Em relação à rocha movimentada, são coletadas amostras em duas direções (FIGURA 3.2): uma paralela ao plano de serragem (amostra F) e outra perpendicular a este plano (amostra L). Tais direções não refletem a estruturação da rocha, mas sim o plano escolhido para a transformação em ladrilhos.

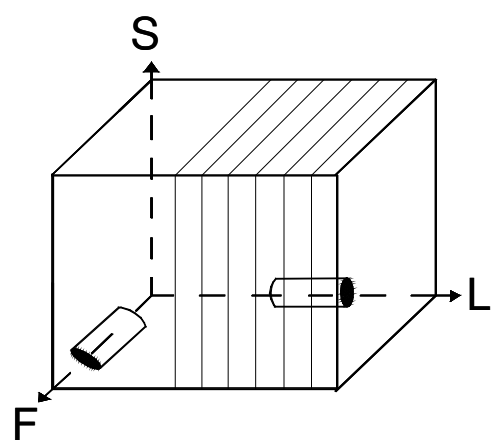

Figura 3.2 - Bloco esquemático de rocha movimentada (sem escala), orientado de acordo com a programação de serragem. Observar as direções de amostragem dos corpos de prova para determinação da resistência à compressão: $\mathbf{F}$ - frontal e $\mathbf{L}$ - lateral (RIBEIRO, 2005).

Os resultados da tensão de ruptura na compressão ( $C$, em $M P a)$, são determinados pela relação:

$$
C=\frac{W}{A}
$$

onde: $\mathrm{W}$ - força de ruptura, em $\mathrm{kN}$ e $\mathrm{A}$ - área de carga do corpo de prova, em $\mathrm{m}^{2}$. 


\subsubsection{Resistência à Tração Na Flexão}

Também denominada flexão por carregamento em três pontos, ou ainda, módulo de ruptura, é regida pela norma NBR 12763 (ABNT, 1992b) e determina a tensão $(\mathrm{MPa})$ que provoca a ruptura da rocha quando submetida a esforços flexores.

Para rochas utilizadas na forma de placas o ensaio mais representativo é o de flexão por carregamento em 4 pontos. No caso de rochas movimentadas, estes ensaios são determinados em amostras retiradas na paralela ao plano de serragem, sendo uma paralela a outra (amostra $\mathbf{F}$ - horizontal e $\mathbf{S}$ - vertical). ( $\mathrm{F} \mathrm{e} \mathrm{S}$ ) dos corpos de prova destinados aos ensaios de velocidade de propagação de ondas longitudinais e de dilatação térmica linear (FIGURA 3.3).

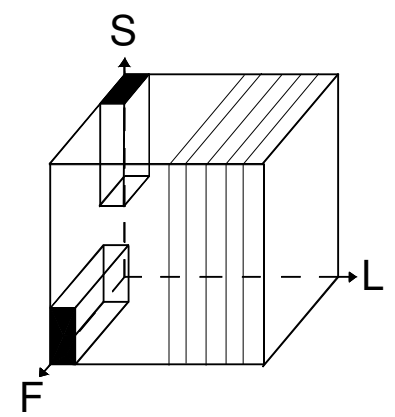

Figura 3.3 - Bloco esquemático de uma rocha movimentada, orientado de acordo com a programação de serragem. Observar as direções de amostragem: F e S (RIBEIRO, 2005).

\subsection{TIPOS DE TÉCNICAS DE ASSENTAMENTO DE PLACAS}

Nos revestimentos de edificações podem ser utilizados vários materiais, dentre eles, placas cerâmicas e de rochas. Existem várias pesquisas, normas e especificações para a fixação de material cerâmico, o que não ocorre para placas de rocha, existindo somente normas que visam a segurança e se preocupam com a argamassa, não com a rocha.

Há aproximadamente duas décadas, foram introduzidas técnicas modernas de assentamento, desenvolvidas nos Estados Unidos e na Alemanha, que utilizam componentes metálicos para a fixação das placas em fachadas, conhecidos como "inserts".

Porém, essa técnica necessita de um conhecimento do comportamento estrutural da placa de rocha, da realização de um projeto estrutural, da correta especificação 
do tipo de rocha, do material dos inserts e da correta forma de fixá-los. Muitas vezes, os construtores negligenciam a natureza das rochas e as propriedades dos aços utilizados nos inserts, não levando em consideração também à agressividade do meio sobre esses materiais.

As placas cerâmicas podem ser fixadas com argamassas comuns, compostas de cimento, areia e cal, feitas em canteiros de obras ou argamassas colantes. Estas últimas são classificadas de acordo com seu desempenho nos ensaios de tempo em aberto (ABNT NBR14083, 2004), tempo que a argamassa ainda mantem suas propriedades (trabalhabilidade e aderência), deslizamento sobre cordão (ABNT NBR 14805, 2004) e arrancamento (ABNT NBR 14804, 2004). Representadas por siglas, segundo a ABNT norma NBR 14081 (2004):

$\mathrm{ACl}$ - Interior: Argamassa com características de resistência às solicitações mecânicas e termoigrométricas típicas de revestimentos internos, com exceção daqueles aplicados em saunas, churrasqueiras, estufas e outros revestimentos especiais. O tempo em aberto deve ser no mínimo de 15 minutos;

ACII - Exterior: Argamassas com características de adesividade que permitem absorver os esforços existentes em revestimentos de pisos e paredes externas, decorrentes de ciclos de flutuação térmica e higrométrica, da ação de chuva e/ou vento, da ação de cargas como as decorrentes do movimento de pedestres, em áreas públicas, e de máquinas ou equipamentos leves sobre rodízios não metálicos. O tempo em aberto deve ser no mínimo de 20 minutos;

ACIII - Alta Resistência: Argamassa que apresenta propriedades de modo a resistir a altas tensões de cisalhamento nas interfaces substrato/adesivo e placas cerâmicas/adesivo, juntamente com uma aderência superior entre as interfaces em relação às argamassas dos tipos I e II. São especialmente indicadas para usos em saunas, piscinas, estufas e ambientes similares. $O$ tempo em aberto deve ser no mínimo de 20 minutos;

ACIIIE - Especial: Semelhantes ao tipo III, porém com o tempo em aberto estendido. O tempo em aberto deve ser no mínimo de 30 minutos.

Existem também no mercado argamassas colante específica para mármore, granito e ardósia, para assentar ladrilhos com espessura e dimensões padronizadas, em pisos e paredes, saunas úmidas e pisos aquecidos até $70^{\circ} \mathrm{C}$, áreas de grande movimentação de pedestres e fachadas. No assentamento em fachadas a altura máxima permitida é de $3 \mathrm{~m}$ do piso. 
As argamassas colantes estão substituindo as argamassas convencionais, já que oferecem maior qualidade, rapidez e homogeneidade no processo de fixação das placas, razões pelas quais, torna-se importante o seu estudo.

\subsection{PROBlemas COM A UTILIZAÇÃO DE ROCHAS COMO REVESTIMENTO}

No Brasil as técnicas de aplicação de rochas ornamentais em revestimento por meio de argamassas não acompanharam o desenvolvimento do setor produtivo. Os sistemas de revestimentos com rochas ainda são baseados no empirismo, não existindo uma metodologia para a especificação tanto da rocha, quanto dos materiais utilizados na fixação.

Devido à falta de conhecimento na especificação das argamassas e de erros no procedimento de execução do revestimento com placas de rocha, ainda que muito utilizados, diversos tipos de patologias ocorrem, desde simples manchas que interferem apenas na estética, até mesmo fissuras, quebras e destacamentos, que causam grandes prejuízos e comprometem toda a sua funcionalidade e segurança.

Tanto para pisos como para paredes, é possível apontar que as principais causas dos problemas patológicos são: a má aderência entre a placa e a argamassa de assentamento ou desta com o substrato, a deterioração da argamassa de assentamento ou de rejuntamento, a deterioração de produtos "impermeabilizantes", os procedimentos ou produtos de limpeza e as alterações na própria rocha.

Percebe-se que essas causas estão ligadas aos diferentes componentes utilizados para a produção da argamassa, seja por inadequadas composições e/ou especificações na etapa execução.

A solução dos problemas apontados vem sendo discutida em estudos mais detalhados e em projetos de revestimentos de edificações, levando-se em conta as características das rochas (mineralogia/textura), assim como os materiais utilizados na fixação. 


\subsection{ARGAMASSA COLANTE}

De acordo com FIORITO (1994), a argamassa colante é uma mistura constituída de aglomerantes hidráulicos, agregados minerais e aditivos. Quando preparada em obra, com adição exclusiva de água, forma uma massa viscosa, plástica e aderente empregada no assentamento de peças cerâmicas para revestimento ou pedras de revestimento.

Os fatores que influenciam o desempenho das argamassas, de maneira geral, são diversos e difíceis de serem definidos e controlados.

As propriedades das argamassas são modificadas pela adequada incorporação de aditivos ou adições. As propriedades reológicas e mecânicas dos concretos e argamassas variam de acordo com os materiais constituintes, procedimento de execução e condições ambientais no momento do preparo, além da cura.

Fatores como a composição do cimento (teor de $\mathrm{C}_{3} \mathrm{~S}, \mathrm{C}_{2} \mathrm{~S}, \mathrm{C}_{3} \mathrm{~A}$ e $\mathrm{C}_{4} \mathrm{AF}$ ), quantidade e tipo de aditivo (e impurezas), determinam propriedades físicas e mecânicas tais como viscosidade, tempo em aberto, resistência de aderência, deslizamento e resistência mecânica à flexão.

A adesão deve ser tratada microscopicamente como um fenômeno físico-químico interfacial, considerando-se os seguintes fatores (YOSOMIYA et al., 1990):

- Ligamento mecânico, como o efeito de ancoragem. Neste mecanismo, é imprescindível aumentar a área molhada, ou seja, aumentar a área de contato.

- Ligamento por interação física, através das forças intermoleculares (Van der Waals).

- Ligamento por interação química, onde as ligações por pontes de hidrogênio, ligações covalentes são consideradas.

Para garantir a fixação por um longo período, a argamassa deve estar presente nos poros do tardoz cerâmico e nos poros do substrato, quando se tratar de revestimentos porosos (absorção de água maior ou igual a 4\%). Para revestimentos com pouca ou nenhuma absorção de água (0 a 3\% - granitos, mármores, ardósias e porcelanatos) a aderência mecânica é restringida. A fixação é física, que está intimamente relacionada com a área de contato superficial entre os materiais aderidos e pela hidratação do cimento, e também pode ser química, que se dá por 
ação de forças eletrostáticas entre as moléculas do adesivo e as moléculas dos materiais a serem unidos (YOSOMIYA et al., 1990).

Para saber como a argamassa se comporta é necessário estudar as propriedades dos materiais que serão adicionados aos materiais básicos (cimento, areia e água).

\subsubsection{Cimento}

Um dos principais constituintes da argamassa colante é o cimento Portland. $O$ cimento trata-se, basicamente, de uma mistura bem proporcionada de matérias primas contendo óxidos $\left(\mathrm{CaO}, \mathrm{SiO}_{2}, \mathrm{Al}_{2} \mathrm{O}_{3}, \mathrm{Fe}_{2} \mathrm{O}_{3}\right)$ que constituem o clinquer. $\mathrm{O}$ clinquer tem como principal matérias primas o calcário e a argila, obtidos de jazidas situadas nas proximidades das fabricas de cimento. A rocha calcária é inicialmente britada, depois moída e em seguida misturada com a argila moída. Esta mistura passa através de um forno giratório de grande diâmetro e comprimento, após este processo é formado o clínquer sob forma de pelotas.

No processo final de produção do cimento Portland ocorre a moagem do clínquer em partículas menores que $75 \mu \mathrm{m}$ de diâmetro. As reações químicas que ocorrem no sistema de fornos do cimento são representadas, aproximadamente, como as seguintes (METHA, 1994):

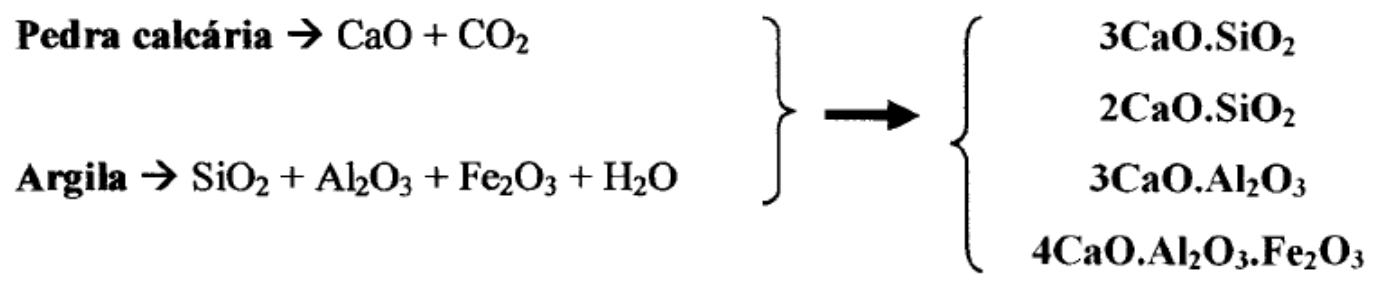

Todos os compostos presentes no clínquer são anidros, porém, reagem quando em contato com a água e formam compostos hidratados estáveis, resultantes de reações exotérmicas. Portanto, o cimento Portland é constituído por vários compostos (silicatos e aluminatos de cálcio). 


\subsubsection{Superplastificante}

Os aditivos superplastificantes melhoram a trabalhabilidade das argamassas e concretos no estado fresco, com a finalidade de reduzir a relação água/aglomerante. A ação dos superplastificantes nas argamassas é dependente de diversos fatores: natureza química e quantidade do superplastificante, distribuição do tamanho de partículas e a mineralogia do cimento, a proporção água/cimento, o tempo de cura e o procedimento de mistura.

Os tipos de superplastificantes comerciais são (AITCIN, 2000):

- Sais sulfonados de policondensados de naftaleno e formaldeído, usualmente denominados polinaftalenos sulfonados ou mais simplesmente plastificantes de naftaleno;

- Sais sulfonados de policondensados de melanina e formadeído, usualmente denominados polimelaninas sulfonadas ou mais simplesmente superplastificantes de melanina;

- Lignossulfonatos com teores muito baixo de açúcar e de tensoativos;

- Poliacrilatos.

A interação entre o cimento e aditivos superplastificantes é objeto de estudo de diversas pesquisas, podendo-se mencionar que (COLLEPARDI, 1998; PINTO \& HOVER, 1999):

- As propriedades reológicas de pastas de cimento preparadas com adição de diferentes aditivos a um só tipo de cimento variam de acordo com o tipo de aditivo;

- A consistência da pasta de cimento preparada com mesmo aditivo a diferentes tipos de cimento varia de acordo com o tipo de cimento;

- A interação entre cimento e aditivo não afeta somente a fluidez da pasta de cimento, mas pode acelerar ou retardar a cura da pasta.

O mecanismo de ação dos superplastificantes baseia-se na existência de forças de repulsão eletrostáticas, que causam dispersão entre as partículas de cimento pela mudança de polaridade na superfície das mesmas. Os superplastificantes também contribuem para diminuir a tensão superficial da água e produzir filmes lubrificantes na superfície das partículas. 


\subsubsection{Efeito Da Adição De Látices Poliméricos Às Argamassas}

Em material poroso ocorre a aderência mecânica resultante da penetração de pasta de cimento nos poros da placas que, após o endurecimento, são criados pontos de embricamento mecânico, sendo a porosidade superficial do tardoz das placas essencial para promover a aderência.

A baixíssima porosidade dos granitos restringe a penetração de pasta de cimento para o mecanismo de aderência mecânica, o que viabiliza a adição de polímeros que proporcionem propriedades de aderência química, flexibilidade e capacidade de retenção de água.

Segundo Ulrich (1993), os polímeros acrílicos são derivados dos ácidos, $\mathrm{CH}_{2}=\mathrm{CHC}(\mathrm{O}) \mathrm{OR}$, onde a natureza do grupo $\mathrm{R}$ determina as propriedades dos polímeros. A maioria dos polímeros acrílicos produzidos comercialmente são copolímeros de um monômero acrílico com um ou mais monômeros diferentes.

O ácido acrílico, líquido incolor, solúvel em água, capaz de reagir com diversos compostos orgânicos e inorgânicos para a formação de um copolímero, tais como ésteres acrílicos, ésteres metacrílicos, ésteres de ácido maleico, vinil-acetato, estireno, butadieno e etileno. Os copolímeros acrílicos são empregados devido a suas características de aderência, durabilidade e resistência química (ULRICH,1993).

- As argamassas modificadas com polímero têm sido objetos de estudo em diversas pesquisas no Brasil e em outros países, constatando-se que estas adições podem melhorar significativamente as propriedades de compósitos de cimento Portland. Os polímeros são adicionados na forma de dispersão (látex ou emulsão) às argamassas de cimento Portland durante a mistura.

O látex consiste na dispersão de partículas de polímero orgânico em água formando um fluído leitoso, geralmente branco, sendo as seguintes propriedades as mais importantes para a adequada aplicação: teor de sólidos, $\mathrm{pH}$, viscosidade, tipo de estabilizador e temperatura mínima de formação de filme (ACI, 1995; LAVELLE, 1988; WALTERS, 1987).

Os polímeros acrílicos empregados com cimento Portland são compostos principalmente por poliacrilatos e polimetacrilatos, resultantes da polimerização de derivados de ácidos acrílicos e metacrílicos (ACI, 1995; LAVELLE, 1988; WALTERS, 
1987). Em matrizes de cimento fresco, as partículas de polímeros agem como lubrificantes melhorando a trabalhabilidade e diminuindo a proporção água/cimento.

Argamassas com adições de polímero apresentam boas propriedades no estado fresco, tais como aumento na incorporação de ar resultando na melhora da trabalhabilidade e capacidade de retenção de água, favorecidas pela formação de filme ou membrana polimérica que restringe a perda de água por evaporação para o ambiente e por absorção pelo substrato, aumentando o tempo de hidratação do cimento (OHAMA, 1998).

O látex acrílico adicionado às argamassas proporciona o aumento da resistência à flexão, resistência à tração, resistência de aderência, resistência ao impacto, impermeabilidade, excelente durabilidade em ambientes externos e manutenção das propriedades mesmo quando expostas à radiação ultravioleta, à chuva e umidade. Portanto, estas argamassas são indicadas para revestimentos externos e assentamento de placas (ACI, 1995; OHAMA, 1997).

A resistência de aderência de argamassas modificadas com polímeros é influenciada significativamente pela proporção de polímero/cimento, pela condição de cura e pelas propriedades do substrato ( $\mathrm{ACl}$, op cit).

\subsubsection{Sílica Ativa}

A sílica ativa empregada na construção civil no Brasil consiste no resíduo da indústria de transformação para obtenção do silício metálico e ligas à base de silício, sendo conhecida por várias denominações: sílica de fumaça, sílica de fumaça condensada, pó de ferro-silício, sílica amorfa, sílica ativa e microssílica. Algumas de suas utilizações finais incluem: a aplicação em cimento e concreto; em refratários, fertilizantes, entre outros.

A sílica ativa (não cristalina) é considerada uma pozolana de alta reatividade com os compostos do cimento Portland, e tem sido objeto de diversas pesquisas sobre concreto de alto desempenho e argamassas para reparos de estruturas danificadas. As características físicas e químicas da microssílica dependem do tipo de liga de silício produzida, tipo de forno, e dos teores de elementos químicos encontrados na matéria-prima, assim, estas propriedades influenciam no seu desempenho em matrizes de cimento. 
Segundo KHAYAT \& AÏTCIN (1991), as principais características da sílica ativa são:

- Consiste em partículas muito finas com diâmetro 100 vezes menor que o cimento Portland, isto é, o diâmetro das partículas varia entre 0,01 a $1 \mu \mathrm{m}$;

- Material composto de partículas esféricas resultantes da condensação do vapor de silício;

- Material amorfo composto de partículas vítreas resultantes da rápida condensação de gás SiO, o qual sofre oxidação quando em contato com o ar.

\subsection{NORMAS - FIXAÇÃO DE PLACAS COM ARGAMASSAS COLANTES}

No site da Weber Quartzolit a referência de três normas da ABNT que foram utilizadas para a realização dos laudos técnicos de argamassas colantes para pedras rústicas, ardósia e mármores são as mesmas normas utilizadas para cerâmicas.

Tendo como base as normas da cerâmica as propriedades das argamassas colantes podem ser divididas em propriedades nos estados fresco e endurecido. Assim como acontece para as argamassas em geral e concretos, o controle das propriedades no estado fresco é importante para a etapa de aplicação, além de influenciar as propriedades das argamassas no estado endurecido quando deverá estar cumprindo sua função de fixar o ladrilho.

A maior parte das propriedades no estado fresco é avaliada por normas internacionais, e algumas são especificadas pela normalização brasileira. A coesão após aplicação indica a facilidade ou não de deslizar a placa sobre a argamassa colante, e, portanto, está relacionada com a propriedade de deslizamento. O tempo em aberto é o tempo o qual é possível o assentamento do ladrilho sobre a argamassa, sem haver prejuízo na aderência.

As propriedades obtidas no estado endurecido podem garantir 0 bom desempenho dessas argamassas ou então denotar suas falhas. A resistência de aderência à tração corresponde à força máxima para a ruptura para uma determinada área de atuação. A flexibilidade das argamassas colantes também é 
uma propriedade importante, principalmente quando em ambientes externos, pois indica a capacidade de absorver ou dissipar as tensões atuantes no revestimento, resultantes da retração e fluência da estrutura de concreto e dos movimentos térmicos da camada de placa (MEDEIROS et al, 1998; RIUNNO, 1992).

As argamassas terão suas propriedades avaliadas seguindo as metodologias descritas nas seguintes normas, com algumas adaptações:

- Determinação do tempo em aberto: NBR 14083 - Argamassa colante industrializada para assentamento de cerâmica - Determinação do tempo em aberto;

- Resistência de aderência: ABNT NBR 14084 (2004) - Argamassa colante industrializada para assentamento de cerâmica - Determinação da resistência de aderência. Como a norma é para cerâmica torna-se necessário estimar um número de corpos-de-prova que seja representativo para as rochas, no presente trabalho foi de 12 corpos-de-prova, o mesmo de Nogami (2007).

- Determinação do deslizamento: ABNT NBR 14085 (2004) - Argamassa colante industrilalizada para assentamento de cerâmica - Determinação do deslizamento. A coesão entre a placa de rocha e a argamassa colante é muito importante, uma vez que a placa de rocha ornamental possui um peso superior ao dobro de uma placa cerâmica;

- Determinação da deformação transversal: UEAtc (1990) - Technical Guide for the Assessment of Ceramic Tile Adhesives. A flexibilidade das argamassas é uma propriedade muito importante no assentamento da placa de rocha, porque ela possui dilatação térmica superior a da placa cerâmica;

\subsubsection{Determinação da resistência de aderência à tração}

O Ensaio de Resistência de Aderência ou Ensaio de Arrancamento é normatizado pela NBR 14084 (ABNT, 2004d) de argamassas colantes industrializadas para cerâmica. Etapas do ensaio: 


\section{- Confecção do substrato padrão:}

O substrato padrão deve ser moldado conforme os procedimentos prescritos na NBR 14082/2004, empregando os seguintes materiais: tela de aço eletrossoldado de malha quadrada com espaçadores, areia, pedrisco (brita 0) e cimento CP II E 32, com relação água/cimento de 0,45 a 0,5 , consumo mínimo de cimento de $400 \mathrm{~kg} / \mathrm{m}^{3}$ e traço indicativo em massa igual à 1:2,58:1,26.

Características do substrato padrão:

Dimensões: $40 \mathrm{~cm} \times 45 \mathrm{~cm} \times 2,5 \mathrm{~cm}$

Traço: 1:2,58:1,26 (em massa)

Absorção de água (NBR 14082/1998, anexo A) inferior a $0,5 \mathrm{~cm}^{2}$

As etapas para a confecção do substrato padrão são:

1. Pesagem dos materiais, conforme as proporções normatizadas;

2. Montagem e limpeza das formas metálicas, para a aplicação de óleo nas superfícies, para facilitar na desmoldagem;

3. Colocação das telas de aço eletrossoldadas com os espaçadores fixados;

4. Preparo do concreto em betoneira;

5. Colocação do concreto no molde até que a tela esteja totalmente recoberta e que o concreto esteja nivelado com as cantoneiras da forma (FIGURA 3.4);

6. Adensamento em mesa vibratória (FIGURA 3.5);

7. Cura do substrato no molde por 24 horas (FIGURA 3.6), seguindo-se então com a desmoldagem;

8. Cura do substrato em imersão de água até completar 7 dias, após é retirado do tanque;

9. Cura do substrato padrão em ambiente climatizado até completar 28 dias, para a realização dos ensaios. 


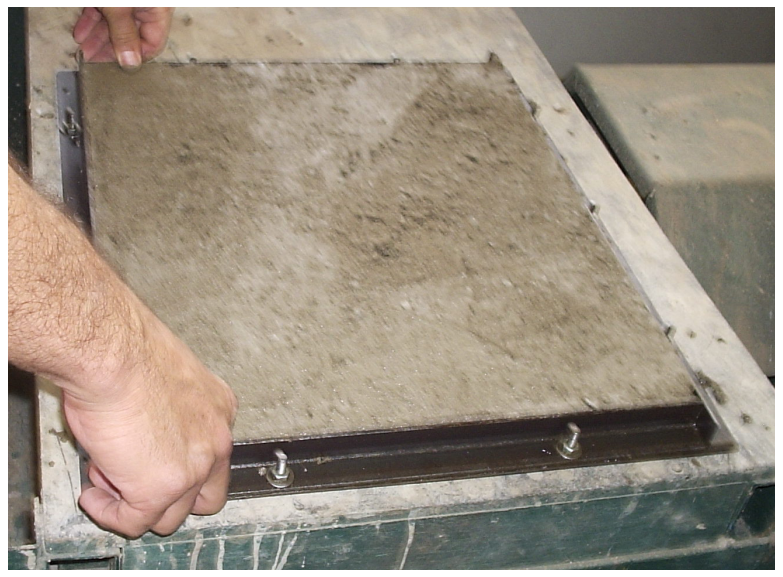

Figura 3.4 - Colocação do concreto no molde até que a tela esteja totalmente recoberta e que o concreto esteja nivelado com as cantoneiras da forma.

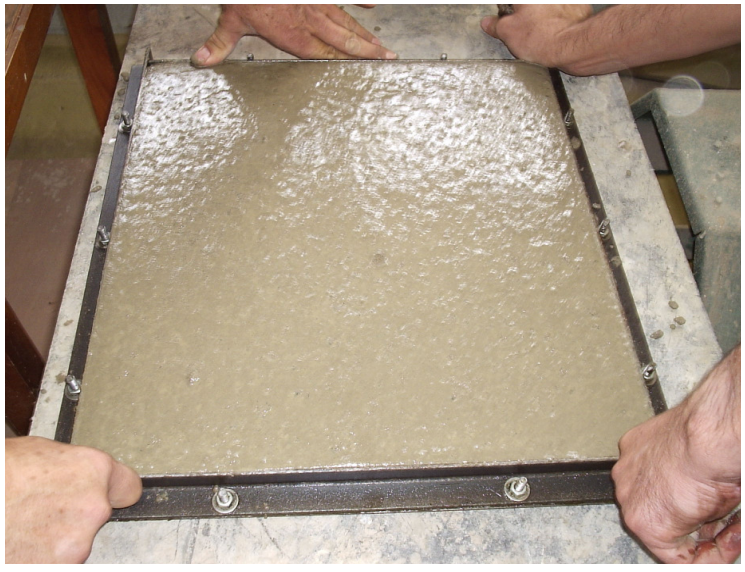

Figura 3.5 - Adensamento em mesa vibratória.

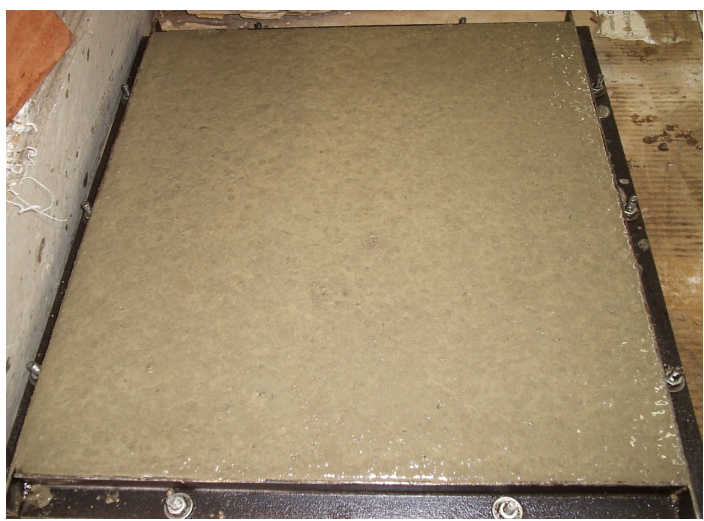

Figura 3.6 - Cura do substrato por 24 horas. 


\section{- Preparação do corpos-de-prova}

Como já salientado, não existem normas para o ensaio de resistência de aderência à tração para rochas, no trabalho de Nogami (2007) as normas da cerâmica foram adaptadas ás rochas e o que diferiu foi o número de corpos-deprova a serem ensaiados para ter um número amostral considerável, já que a rocha não é um material homogêneo e conhecido o procedimento de fabricação, como uma cerâmica.

Na norma de cerâmica são necessários 5 corpos-de-prova, mas para rocha este número não foi suficiente para obter uma média coerente, por ser tratar de um material não homogêneo, sendo ensaiados 12 corpos-de-prova de cada rocha para cada argamassa e descartado os corpos-de-prova que apresentaram valores muito diferentes.

\section{- Determinação da resistência de aderência ao arrancamento por tração.}

A aplicação das argamassas na superfície do substrato deve seguir os procedimentos descritos na NBR 14082 (ABNT, 2004b):

a. O substrato padrão deve estar seco, livre de qualquer partícula solta e isento de manchas de óleo, tintas, gordura ou outras condições que prejudicassem a aderência;

b. Colocar o substrato padrão na posição horizontal e estável sobre a bancada de trabalho, aplicar uma porção de argamassa sobre a face regularizada com régua. Com o lado reto de desempenadeira metálica estender a argamassa apenas sobre a área a ser ensaiada;

c. O lado denteado da desempenadeira deve ser passado ao longo da superfície, firmemente apoiado sobre o substrato e com a lâmina ligeiramente inclinada na direção do movimento;

d. A argamassa acumulada no final da operação deve ser novamente repassada na direção contrária, da mesma forma que a passada inicial;

e. Repetir todo o procedimento;

f. Adicionar argamassa fresca, estendendo o material de maneira uniforme; 
g. Imediatamente a seguir, o lado denteado da desempenadeira deve ser passado na direção longitudinal da superfície, com a lâmina inclinada de $60^{\circ}$ no sentido do movimento;

h. O deslocamento da desempenadeira deve ser realizado com cuidado para a formação de cordões contínuos, de seção uniforme (FIGURA 3.7).

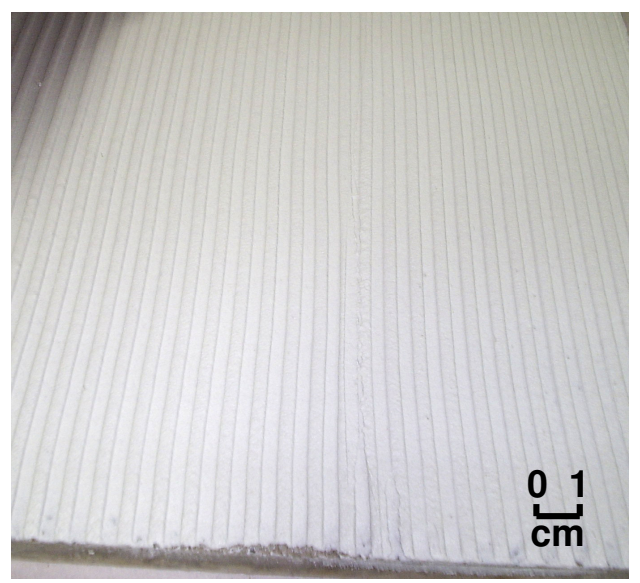

Figura 3.7- Detalhe dos cordões da argamassa colante Industrializada formados pela desempenadeira.

Os corpos-de-prova devem ser assentados no substrato com auxilio de um martelo de borracha para melhor aderência com a argamassa.

O ensaio de arrancamento à tração deve prosseguir depois de 28 dias, seguindo os procedimentos descritos na NBR 14084 (ABNT, 2004d). O equipamento para o arrancamento por tração é monstrado na Figura 3.8. Consta de uma manivela que regula a velocidade de carregamento com precisão de 0,05 kN.

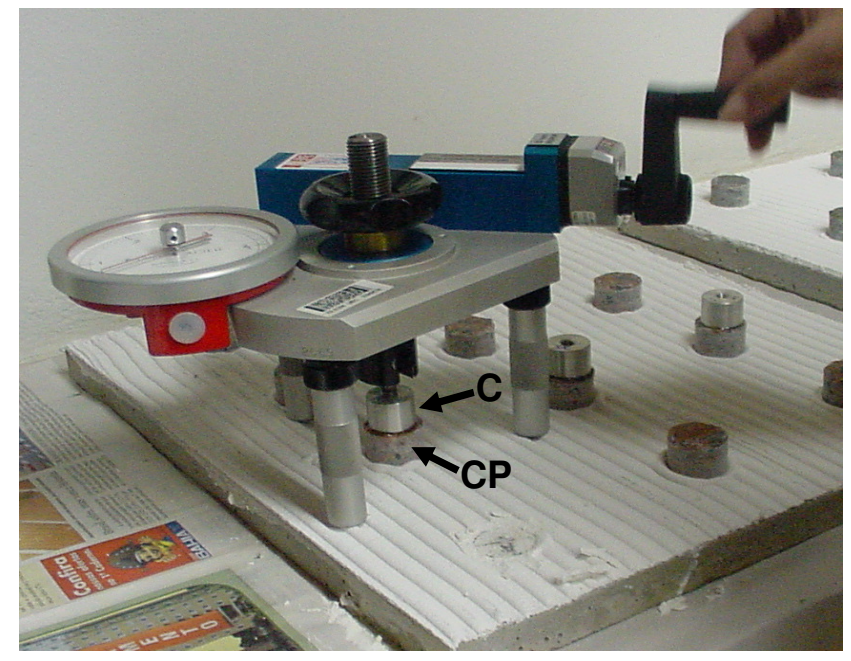

Figura 3.8 - Equipamento utilizado no ensaio de resistência de aderência à tração. (C) componente metálico que é colado no corpo-de-prova e conectado ao equipamento; (CP) Corpo-de-prova. 
A Figura 3.9 mostra a representação do sistema substrato patrão/argamassa/rocha e os locais possíveis de ocorrer a ruptura (1 - rocha; 2 interface rocha/argamassa; 3 - argamassa; 4 - interface argamassa/substrato padrão e 5 - substrato padrão)

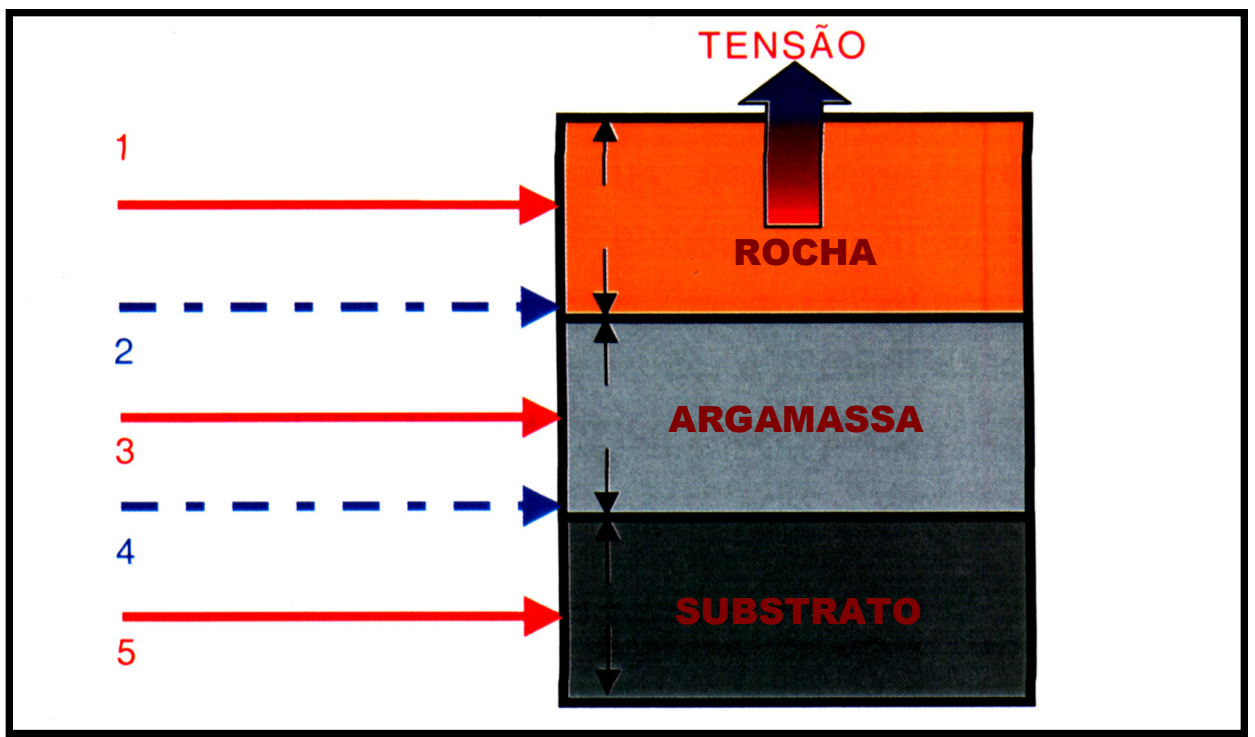

Figura 3.9 - Ilustração das tensões ocorridas durante o ensaio de arrancamento.

\subsubsection{Determinação do tempo em aberto}

O tempo em aberto é o tempo em que a argamassa colante, após ser misturada com água, pode ficar exposta ao ar sem perder suas propriedades de trabalhabilidade e aderência.

A NBR 14083 (ABNT, 2004c) determina o método de ensaio para o tempo em aberto. Sua metodologia descreve que, para o ensaio, a argamassa colante (misturada com a quantidade correta de água) deve ser estendida sobre um substrato padrão e as peças devem ser assentadas em intervalos de 10, 15, 20, 25 e 30 minutos (ou mais tempo que se achar conveniente).

Após a cura (28 dias), realiza-se o ensaio de arrancamento. Uma argamassa possui determinado tempo em aberto, se no ensaio ela apresentar uma resistência ao arrancamento de 0,5 MPa.

O tempo em aberto é afetado pela quantidade de água e pelo tipo/quantidade de retentor. Quanto maior for a quantidade de retentor de água, maior será o tempo que a argamassa poderá permanecer aberta. 


\subsubsection{Determinação do deslizamento}

O Ensaio de deslizamento foi executado segundo a norma NBR 14805 (ABNT, 2004e), utilizando placas de rocha, conforme descrito a seguir:

- Fixação da régua metálica rígida contra a borda longitudinal do substratopadrão, mediante dispositivos de fixação, de modo que os lados da régua e do substrato fiquem coincidentes. Deve ser garantida a condição de horizontalidade da borda inferior da régua quando o substrato-padrão for colocado na posição vertical. Colar a fita adesiva sobre o substrato-padrão de modo que a sua aresta fique rente à régua.

- Preparar e estender a argamassa sobre o substrato-padrão limpo, na posição horizontal seguindo as prescrições indicadas na seção 8 da NBR 14802 (ABNT, 2004b), tomando as precauções para que a argamassa se sobreponha ligeiramente à fita adesiva e que os cordões fiquem perpendiculares à régua metálica.

- Retirar a fita adesiva e imediatamente posicionar dois espaçadores para cada placa cerâmica, separados aproximadamente $25 \mathrm{~mm}$ entre si, encostados contra a régua metálica.

- Após 2 min. da aplicação da argamassa, posicionar três placas cerâmicas, com lado do tardoz em contato com a argamassa, de modo que uma de suas arestas fique encostada, contra os espaçadores. Posicionar cuidadosamente as massas-padrão sobre as placas cerâmicas, aguardar 30 seg. e retirá-las.

- Retirar cuidadosamente os espaçadores e medir, com o paquímetro, em dois pontos de cada placa cerâmica, a distância (Li) entre a borda da placa cerâmica e a régua metálica.

- Mover suavemente o substrato-padrão, deixando-o na posição vertical, com a régua metálica e as placas cerâmicas assentadas na parte superior. Realizar esta operação sem golpes ou vibração. Decorridos $20 \mathrm{~min}$ da leitura inicial, medir novamente a separação (Lf) nos mesmos pares de pontos. Registrar os valores com aproximação mínima de $0,1 \mathrm{~mm}$. Calcular a média dos valores.

$O$ resultado de deslizamento deve atender as especificações da norma $(\leq 0,5 \mathrm{~mm})$. 


\subsubsection{Flexibilidade}

As exigências a que estão submetidas as argamassas colantes para fachadas são mais severas sob vários aspectos do que as de uma argamassa utilizada em uma área interna.

Fachadas de edifícios sofrem além das variações de temperatura e umidade ocorridas ao longo do dia, sofrem variações estruturais. Estas oscilações estruturais ocorrem devido à uma série de fatores, tais como acomodações estruturais, acomodações do solo, ação do vento, etc.

O revestimento está sujeito a deformações que resultam em tensões entre as camadas do revestimento e também sobre os componentes do revestimento: base, argamassa e placa de rocha.

Para não causar danos ao revestimento, que resultam em descolamento da placa, as tensões geradas necessitam ser dissipadas. Um dos principais critérios para compatibilizar os requisitos da argamassa colante com as deformações do revestimento é a utilização de argamassa com capacidade de deformação adequada (AKIAMA ET AL., 1997)

Considerando uma fachada que está submetida à ação de intempéries e às movimentações estruturais, podemos ter um acúmulo de tensões que geram uma força cisalhante entre a argamassa e a placa de revestimento, podendo correlacionar a resistência à flexão com a resistência ao cisalhamento (FIGURA 3.10.). 


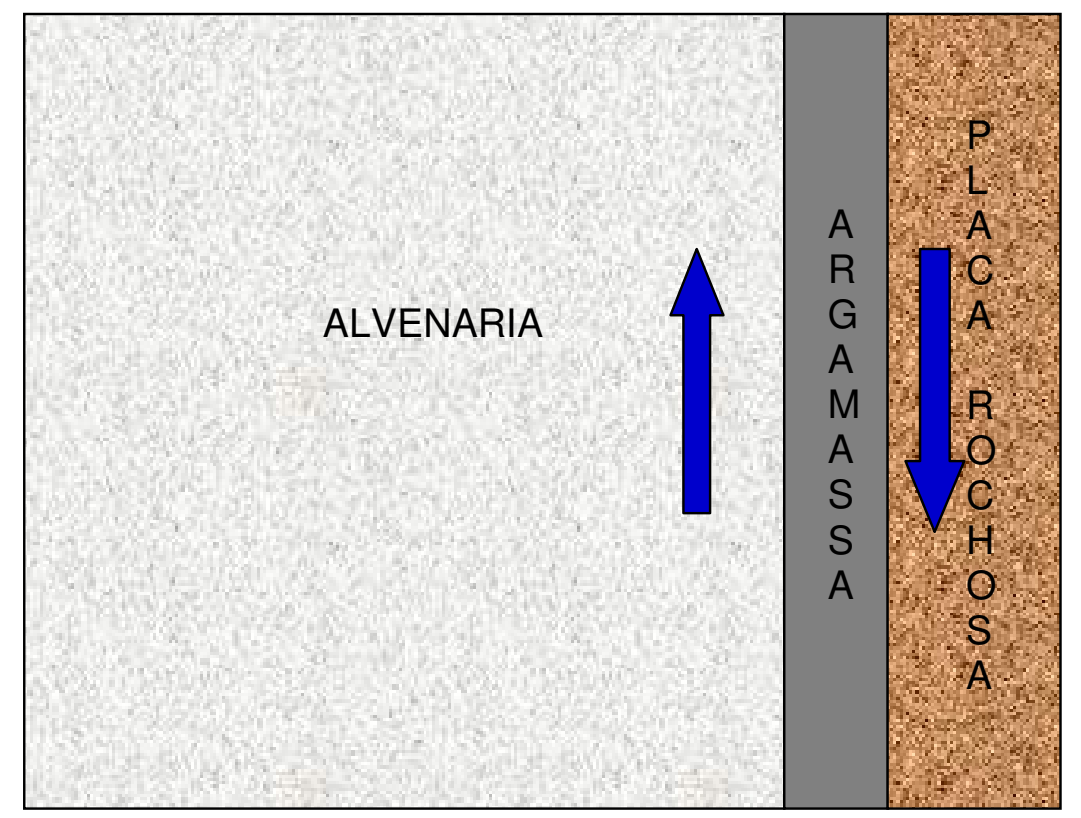

Figura 3.10 - Tensões cisalhantes.

Podemos notar que neste caso enquanto o conjunto substrato+argamassa sofre a ação de uma força ascendente, a placa (por ser rígida) sofre uma ação de força contrária.

Quanto maior for à flexibilidade da argamassa, maior será a sua capacidade de mesma se deformar quando houver solicitações de movimentação da estrutura do edifício.

Sendo a força cisalhante predominante na interface argamassa/placa, é necessário que a argamassa possua uma resistência ao cisalhamento capaz de suportar essa tensão sem romper.

\subsubsection{Estudo da microestrutura do conjunto substrato/argamassa/rocha}

É consenso entre os pesquisadores sobre a tecnologia de produção das matrizes cimentíceas que as propriedades dos materiais são influenciadas diretamente pela sua microestrutura. Assim, diversos trabalhos têm sido realizados no Brasil e outros países com o objetivo de estudar a microestrutura de argamassas e de concretos, relacionando-a com as suas propriedades.

A observação das estruturas encontradas na natureza utilizando microscopia óptica, como uma extensão natural da observação a olho nu, representou papel importante no surgimento das ciências da natureza, tanto das ciências biológicas, 
como a histologia, anatomia, etc. assim como em mineralogia, petrografia, gênese de rochas, etc. e continua sendo uma técnica importante em inúmeras áreas da ciência, complementada pela microscopia eletrônica (GOLDENSTEIN, 2011).

\section{- Microscopia óptica:}

Dois tipos básicos de microscopia óptica são empregados em geologia:

Luz Transmitida: utilizada para a análise de minerais transparentes, onde a luz atravessa o objeto a ser estudado e atinge a objetiva;

Luz Refletida: utilizada para análise de minerais opacos, sendo que, a luz incide na superfície do mineral e é refletida em direção a objetiva.

\section{Tipos de laminas preparadas para análises microscópicas com luz transmitida}

A análise de minerais transparentes com o auxílio de microscopia óptica de transmissão é feita por meio de: Lâminas delgadas ou então Lâminas de pó ou de material granulado.

Lâminas Delgadas: são obtidas através de uma secção extremamente fina (da ordem de 0,03 $\mathrm{mm}$ ) de uma rocha, solo ou mineral. Sua vantagem principal é que todos os cristais e/ou mineras presentes na seção tem a mesma espessura, o que permite determinar uma série de propriedades ópticas. Esta técnica foi usada na presente pesquisa para estudo da interação argamassa/ rocha. 


\section{4 - MATERIAIS}

\subsection{SELEÇÃO DOS TIPOS DE ROCHAS DE REVESTIMENTO E SEUS PRINCIPAIS MINERAIS}

A norma ABNT NBR 15012:2003, em semelhança com a norma ASTM C 119:2003, define rocha ornamental como "material rochoso natural submetido a diversos graus ou tipos de beneficiamento, utilizado para exercer função estética".

Rocha para revestimento é definida pela ABNT, como "rocha natural que, submetida a processos diversos e graus variados de desdobramento e beneficiamento, é utilizada no acabamento de superfícies, especialmente pisos e fachadas, em obras de construção civil". Essa definição pode ser considerada similar à que a American Society for Testing and Materials (ASTM, 2001) propõe para dimension stone: pedra natural que foi selecionada, regularizada ou cortada em tamanhos e formas especificados ou indicados, com ou sem uma ou mais superfícies mecanicamente acabadas.

$\mathrm{Na}$ escolha de rochas ornamentais, o fator estético é muitas vezes decisivo. Ele é resultado da harmonia entre as cores, tamanhos, formas e arranjo entre os minerais. Essas características ficam mais realçadas pelo acabamento dado à superfície da rocha, principalmente o polimento.

As rochas utilizadas para o desenvolvimento da presente pesquisa são de grande aceitação no mercado. Foram escolhidos oito tipos de "granitos" e um "mármore". Quanto aos "granitos" convêm lembrar que o Brasil se destaca pela sua grande variedade cromática e textural.

\subsubsection{Granitos}

As análises petrográficas, descrições macro e microscópicas e as caracterizações tecnológicas dos "granitos" selecionados para estudos, foram cedidas pelo professor Dr. Antonio Carlos Artur do Departamento de Petrologia e Metalogenia do IGCE/UNESP - Instituto de Geociências e ciências exatas/Universidades Estadual Paulista - Rio Claro. 


\subsubsection{Preto São Gabriel (Hiperstênio Diorito)}

Ocorre no município de São Rafael, cerca de $20 \mathrm{~km}$ a nordeste de Colatina, Espírito Santo (FIGURA 4.1).

\section{Análise Petrográfica}

Sigla Amostra: PSG

Natureza da Rocha: Rocha Magmática

Classificação Petrográfica: Hiperstênio diorito

Nome Comercial: Preto São Gabriel

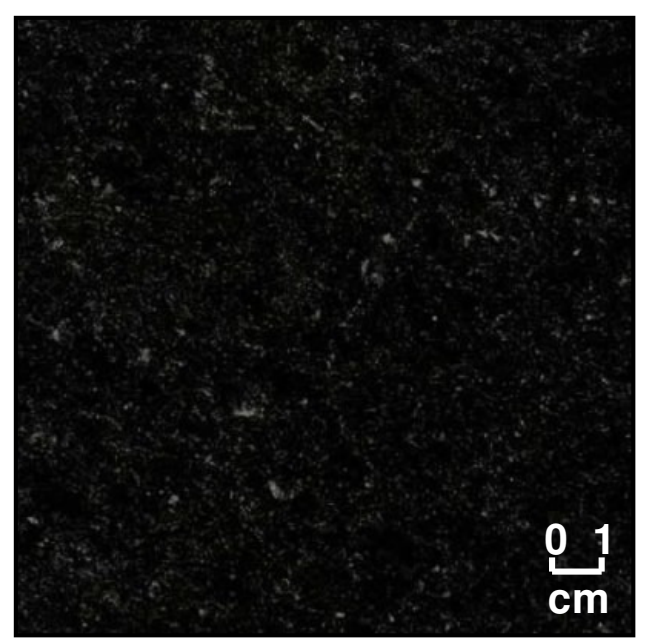

Figura 4.1 - "Granito” Preto São Gabriel.

\section{Descrição Macroscópica}

Rocha de cor cinza escura esverdeada, com estrutura fanerítica inequigranular média a fina. Possui uma foliação discreta, marcada pela orientação dos minerais máficos.

A rocha está pouco alterada na forma de pequenas cavidades associadas aos minerais escuros e argilominerais no feldspato potássio e plagioclásio. O grau de microfissuramento é mediano, sendo controlado principalmente pelas clivagens do hiperstênio.

O plagioclásio (andesina) apresenta forma subedral de hábito tabular, com cristais com cerca de $0,7 \mathrm{~cm}$ de comprimento. A biotita exibe tamanhos variados, desde sub-milimétricos até 2 e $3 \mathrm{~mm}$, podendo formar agregados de lamelas com 
até $5 \mathrm{~mm}$, com lamelas bem definidas. Os demais máficos (hiperstênio e hornblenda) ocorrem na forma de pequenos prismas, bastante difíceis de enxergar e diferenciar a olho nu dado a coloração escura da amostra.

Os minerais opacos são constituídos essencialmente por magnetita. Aparecem pontuando toda a amostra, estando parcialmente associados aos minerais máficos de uma forma geral. Como minerais traços associados à magnetita estão titanita, com seu característico hábito em cunha, e sulfetos, visíveis na forma de pequenos pontos dourados estremamente raros nas amostras.

Tabela 4.1 - Composição Mineralógica do Preto São Gabriel

\begin{tabular}{c|c}
\hline Composição Mineralógica & (\% modal) \\
\hline Quartzo & 3,0 \\
Feldspato Potássico & 4,4 \\
Plagioclásio (Andesina) & 58,5 \\
Hornblenda & 5,3 \\
Biotita & 10,3 \\
Hiperstênio & 10,1 \\
Opacos & 8,4 \\
\hline
\end{tabular}

\section{Caracterização Tecnológica}

Massa Específica: $2.960 \mathrm{~kg} / \mathrm{m}^{3}$

Porosidade: 0,96\%

Absorção D’água: 0,33 \%

Resistência à Compressão Simples: 113,7 MPa

Resistência ao Desgaste Amsler: 1,00mm

Coeficiente de Dilatação Térmica Linear: 6,6 . 10-3 mm/m ${ }^{\circ} \mathrm{C}$.

\subsubsection{Azul Fantástico (Monzogranito Megaporfirítico Gnaissificado)}

Ocorre na porção nordeste do Município de Bragança Paulista - SP (FIGURA 4.2). 


\section{Análise Petrográfica}

Sigla Amostra: AF

Natureza da Rocha: Rocha Magmática

Classificação Petrográfica: Monzogranito Porfiróide Serial Gnaissificado

Nome Comercial: Azul Fantástico

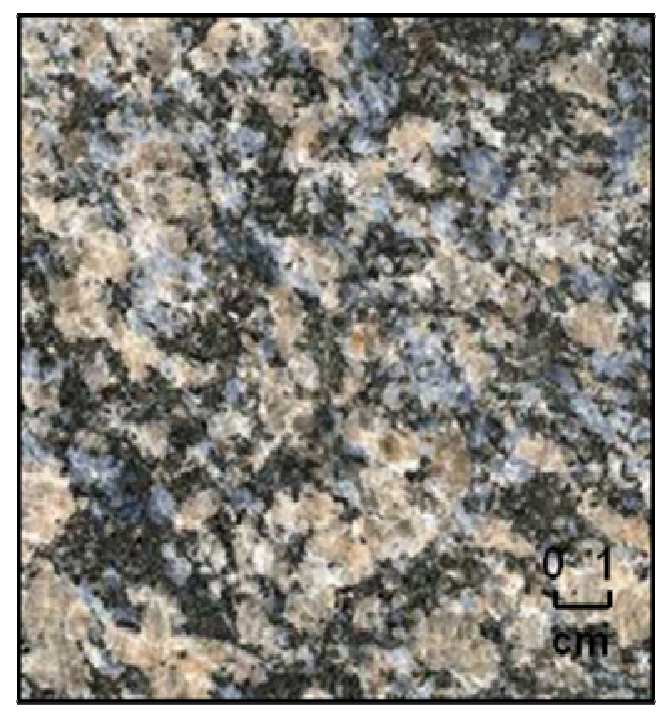

Figura 4.2 - "Granito" Azul Fantástico.

\section{Descrição Macroscópica}

Rocha de aspecto estético exótico em função da presença de cristais azulados de quartzo, róseos a acastanhados de feldspatos e pontuações pretas de biotita, classificada petrograficamente como biotita monzogranito megaporfirítico serial gnaissificado. A foliação gnáissica é marcada pela maior ou menor isorientação dos megacristais de feldspato potássico e de lamelas de biotita, apresentando faixas e lentes mais deformadas que outras porções da rocha. Quando há presença intensa de veios feldspáticos métricos e espessuras milimétricas o material ganha a designação comercial de Azul Fantasia ou Azul Florido.

A textura é megaporfirítica serial com matriz inequigranular média a grossa, hipidiomórfica, com grãos de dimensões médias entre $2 \mathrm{~mm}$ e $8 \mathrm{~mm}$, gradando até as dimensões dos fenocristais. Estes perfazem cerca de $20 \%$ do volume da rocha e exibem formas retangulares, ovaladas ou irregulares com dimensões que oscilam de $0,5 \mathrm{~cm} \times 2,0 \mathrm{~cm}$ até $2,0 \mathrm{~cm} \times 6,0 \mathrm{~cm}$. Os contatos mais freqüentes na matriz são os côncavo-convexos e lobulados, sendo o tipo plano quase exclusivo da biotita e dos 
agregados de quartzo recristalizados com textura poligonal presentes nas faixas mais afetadas pela protomilonitização. Os fenocristais apresentam contatos côncavo-convexos, lobulados a interlobados e serrilhados.

O microfissuramento é baixo a moderado, caracterizado pelo predomínio de planos intragrãos sobre os intergrãos, ambos bem desenvolvidos e pela baixa comunicação. Podem ocorrer planos preenchidos por sericita, epídoto e carbonatos. Dentre todos os minerais o quartzo é o mais afetado pelo microfissuramento.

A alteração mineral é disseminada, variando de ausente a pouco desenvolvida, principalmente nos feldspatos, especialmente as pertitas do microclínio.

Tabela 4.2 - Composição Mineralógica do Azul Fantástico

\begin{tabular}{c|c}
\hline Composição Mineralógica & (\% modal) \\
\hline Quartzo & 25,0 \\
FeldspatoPotássico (Microclínio) & 15,0 \\
Plagioclásio (Oligoclásio) & 40,0 \\
Biotita & 17,0 \\
Acessórios & 3,0 \\
Secundários & tr \\
\hline
\end{tabular}

* Acessórios: opacos, titanita, apatita, zircão.

* Minerais Secundários: sericita, epidoto, clorita, argilominerais, carbonatos.

\section{Caracterização Tecnológica}

Massa Específica: $2.699 \mathrm{~kg} / \mathrm{m}^{3}$

Porosidade: $0,68 \%$

Absorção D'água: 0,25 \%

Resistência à Compressão Simples: 150,7 MPa

Resistência ao Desgaste Amsler: 0,51 mm

Coeficiente de Dilatação Térmica Linear: $5,9 \cdot 10^{-3} \mathrm{~mm} / \mathrm{m}{ }^{\circ} \mathrm{C}$

\subsubsection{Amarelo Ornamental (Granada Gnaisse Porfiroblástico)}

Extraída no município de Nova Venécia - ES (FIGURA 4.3). 


\section{Análise Petrográfica}

Sigla Amostra: AO

Natureza da Rocha: Rocha Metamórfica

Classificação Petrográfica: Granada Gnaisse Porfiroblástico

Nome Comercial: Amarelo Ornamental

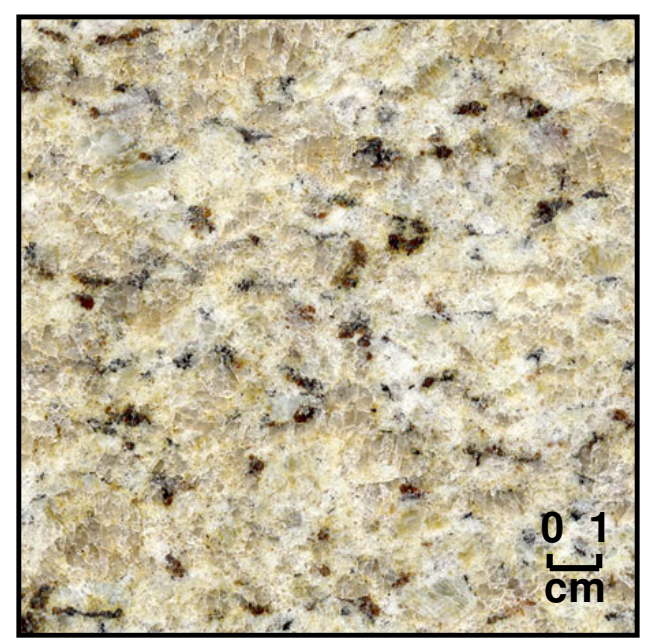

Figura 4.3 - "Granito" Amarelo Ornamental.

\section{Descrição Macroscópica}

O granada gnaisse quartzo-feldspático porfiroblástico, Amarelo Ornamental, pobre em biotita, com estrutura gnáissica homogênea é definido por nítido estiramento mineral. Os megacristais estão representados pelo feldspato potássico com formas ovaladas a fortemente estirados e dimensões seriadas que podem atingir cerca de 4,0 a 5,0cm ao longo do maior eixo, imersos em matriz granoblástica inequigranular média a média/grossa, com granulação predominantemente entre $3,0 \mathrm{~mm}$ a mais ou menos $1,5 \mathrm{~cm}$. A granada perfaz cerca de 3,0 a 4,0\% do volume da rocha e se apresenta como cristais tanto individualizados, com dimensões médias entre 2 e $5 \mathrm{~mm}$, quanto pequenos agregados irregulares a arredondados ou mesmo lineares que podem atingir pouco mais de $1,0 \mathrm{~cm}$, distribuídos de forma mais ou menos homogênea pela rocha. A coloração amarela acastanhada da rocha relaciona-se a discretos efeitos de oxidação de determinados minerais. 
Apresenta uma estrutura anisotrópica, caracterizada por moderada a elevada orientação mineral e textura granoblástica inequigranular, de granulação fina a grossa. A orientação mineral é marcada pelo estiramento de cristais de quartzo, feldspatos e isoorientação de delgadas concentrações lineares descontínuas de biotita. Os contatos minerais são côncavo-convexos a lobulados e localmente com típico padrão poligonalizado, denotando boa recristalização metamórfica e, consequentemente, com bom entrelaçamento mineral.

Moderado a elevado estado microfissural, exibindo microfissuras intragrãos e transgranulares abertas e preenchidas por material sericítico, argilominerais, óxidos e hidróxidos de ferro e algum epidoto e carbonatos. Muitas das microfissuras encontram-se preenchidas por hidróxidos de ferro, provavelmente responsáveis pela coloração acastanhada exibida pela rocha. No geral os cristais de granada são pouco microfissurados.

Fraca a moderada alteração mineral, dada por moderada saussuritização do plagioclásio, acompanhada ou não por efeitos de argilização, além da oxidação e/ou discreta cloritização da biotita e com alguma sericitização do ortoclásio. Localmente ocorrem pequenas concentrações de sillimanita intensamente transformadas para muscovita.

Tabela 4.3 - Composição Mineralógica do Amarelo Ornamental

\begin{tabular}{c|c}
\hline Composição Mineralógica & (\% modal) \\
\hline Quartzo & 30,0 \\
FeldspatoPotássico(Ortoclásio) & 40,0 \\
Plagioclásio (Oligoclásio) & 21,0 \\
Granada & 3,5 \\
Biotita & 2,5 \\
Acessórios & 1,0 \\
Minerais Secundários & 2,0 \\
\hline
\end{tabular}

* Acessórios: opacos, silimanita alterada, zircão, apatita e rutilo

* Minerais Secundários: sericita/muscovita, epidoto, argilominerais, carbonatos, óxidos e hidróxidos de ferro. 


\section{Caracterização Tecnológica}

Massa Específica: $2.660 \mathrm{~kg} / \mathrm{m}^{3}$

Porosidade: 0,96 \%

Absorção D'água: 0,40 \%

Resistência à Compressão Simples:90,2 MPa

Resistência ao Desgaste Amsler: 0,61 mm

Coeficiente de Dilatação Térmica Linear: $7,3 \cdot 10^{-3} \mathrm{~mm} / \mathrm{m}^{\circ} \mathrm{C}$

\subsubsection{Vermelho Brasília (Sienogranito)}

Extraída no município de Jaupací, Estado de Goiás (FIGURA 4.4).

\section{Análise Petrográfica}

Sigla Amostra: VB

Natureza da Rocha: Rocha Magmática

Classificação Petrográfica: Sienogranito

Nome Comercial: Vermelho Brasília

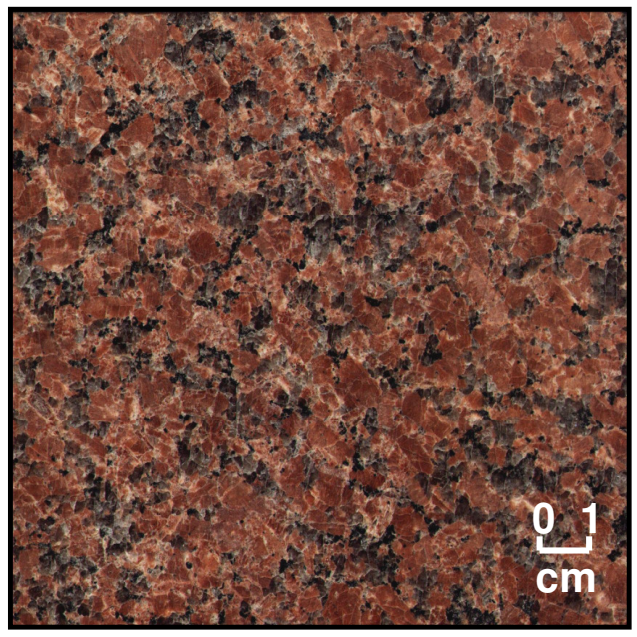

Figura 4.4 - "Granito" Vermelho Brasília. 


\section{Descrição Macroscópica}

Possui uma coloração avermelhada com estrutura discretamente orientada, inequigranular, de granulação grossa. A granulação oscila desde $0,3 \mathrm{~mm}$ até cerca de $5,0 \mathrm{~cm}$ ou mais, com predominância entre 0,5 e 3,0 cm, caracterizada por bom entrelaçamento mineral. Os cristais maiores são de microclínio, os quais exibem formas variadas, podendo ser irregulares, alongados ou ovalados (com dimensões que podem atingir até $2,5 \times 5,0 \mathrm{~cm}$ ) a prismáticos (nestes casos apresentam dimensões que vão desde $0,5 \times 0,5 \times 1,5 \mathrm{~cm}$ a $1,5 \times 2,0 \times 5,0 \mathrm{~cm})$. Apresentam contornos irregulares (devido a corrosão durante cristalização magmática) e mais raramente retilíneos (situação mais freqüente nos cristais prismáticos), o que, apesar da granulação grossa da rocha, se reflete em bom imbricamento mineral e conseqüentemente na coesão da rocha.

Apresenta uma estrutura de discreta orientação de fluxo, evidenciada basicamente por grosseira orientação preferencial dos cristais alongados de microclínio.

Microscopicamente exibe textura fanerítica média a grossa, inequigranular, hipidiomórfica. A granulação média oscila entre 0,5 a $1,5 \mathrm{~cm}$, sendo que o microclínio representa os cristais com as maiores dimensões. Os contatos minerais variam de interlobados (côncavo/convexos) a parcialmente retilíneos, refletindo, no geral, em bom entrelaçamento mineral. Registra-se que os contatos entre os agregados monominerálicos de quartzo e os cristais de feldspatos são irregulares, e que internamente aos referidos agregados os cristais de quartzo exibem entre si contatos preferencialmente retilíneos a levemente lobulados. Já os cristais de microclínio e de plagioclásio exibem contornos externos côncavo/convexos a irregulares, devido a freqüentes feições de corrosão magmática, o que contribui para 0 melhor imbricamento global da rocha.

Baixo microfissuramento, predominantemente intergranular, preferencialmente nos cristais de quartzo. As microfissuras mostram-se tanto fechadas quanto abertas, nestes casos, preenchidas por minerais opacos, sericita e algum epidoto.

Fraca a moderada alteração mineral caracterizada por visível argilomineralização dos cristais de feldspatos, manifestando-se sob forma de manchas pulverulentas, de coloração acastanhada devido ao efeito da pigmentação por óxidos e hidróxidos de 
ferro. Os cristais de plagioclásio são os mais afetados, principalmente em seus núcleos, além de exibirem discreto efeito de sericitização. Já nos cristais de microclínio, apesar de menos afetados, a argilomineralização distribui-se homogeneamente por toda a extensão de sua superfície. Os cristais maiores de biotita encontram-se praticamente inalterados, por vezes com discreta cloritização em bordas com texturas simplictíticas, além de conterem algumas micro-inclusões lineares de agregados de opacos disseminados dispostos ao longo dos planos de clivagem.

Tabela 4.4 - Composição Mineralógica do Vermelho Brasília

\begin{tabular}{c|c}
\hline Composição Mineralógica & (\% modal) \\
\hline Quartzo & 32,0 \\
Feldspato Potássico (Microclínio) & 41,0 \\
Plagioclásio (Oligoclásio) & 16,0 \\
Biotita & 5,0 \\
Acessórios $^{*}$ & 2,0 \\
Minerais Secundários $^{\star *}$ & 4,0 \\
\hline
\end{tabular}

* Acessórios: opacos, apatita, zircão e granada.

** Minerais Secundários: sericita, muscovita, epidoto, clorita, carbonatos, argilo-minerais, hidróxidos de ferro.

\section{Caracterização Tecnológica}

Massa Específica: $2.621 \mathrm{~kg} / \mathrm{m}^{3}$

Porosidade: 0,69 \%

Absorção D'água: 0,26 \%

Resistência à Compressão Simples:209,89 MPA

Resistência ao Desgaste Amsler: 0,51 mm

Coeficiente de Dilatação Térmica Linear: $5,7 \cdot 10^{-3} \mathrm{~mm} / \mathrm{m}^{\circ} \mathrm{C}$

\subsubsection{Cinza Andorinha (Monzogranito)}

Lavra localizada na cidade de Cachoeiro de Itapemirim, Estado do Espírito Santo (FIGURA 4.5) 


\section{Análise Petrográfica}

Sigla Amostra: CA

Natureza da Rocha: Rocha Magmática

Classificação Petrográfica: Monzogranito

Nome Comercial: Cinza Andorinha

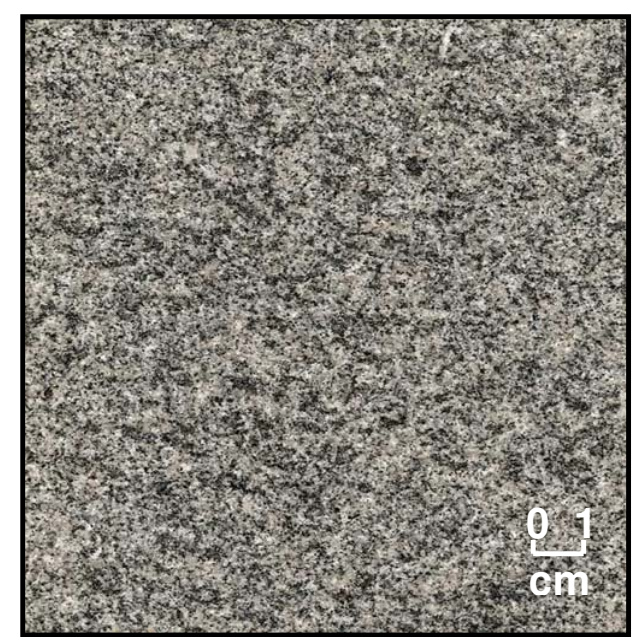

Figura 4.5 - "Granito" Cinza Andorinha.

\section{Descrição Macroscópica}

Considerada uma rocha granítica de coloração cinza claro, com estrutura isotrópica e textura fanerítica equigranular, hipidiomórfica, de granulação média a média/fina, oscilando entre 0,5 a $5,0 \mathrm{~mm}$, com predominância de cristais com dimensões de 1,0 a 2,0 mm.

O seu microfissuramento é moderado, ocorrendo predominantemente microfissuras intragrãos, na maioria das vezes preenchidas por sericita e carbonato. Apresenta baixa intercomunicabilidade, ocorrendo mais freqüentemente nos cristais de quartzo.

Exibe grau de alteração incipiente a moderado, principalmente devida à saussuritização (formação de sericita, epidoto, carbonatos e argilominerais) associada aos cristais de plagioclásio e, mais discretamente, pela cloritização da biotita. A alteração do plagioclásio processa-se tanto sob forma disseminada quanto concentrada nas partes centrais dos cristais. 
Tabela 4.5 - Composição Mineralógica do Cinza Andorinha

\begin{tabular}{c|c}
\hline Composição Mineralógica & (\% modal) \\
\hline Quartzo & 30,0 \\
Feldspato Potássico (Microclínio) & 31,0 \\
Plagioclásio & 25,0 \\
Biotita & 12,0 \\
Acessórios $^{*}$ & 2,0 \\
Minerais Secundários $^{\star *}$ & $\mathrm{tr}$ \\
\hline
\end{tabular}

* Acessórios: opacos, Titanita, zircão, apatita, Allanita.

* *Minerais Secundários: sericita, epidoto, clorita, argilominerais, carbonatos.

\section{Caracterização Tecnológica}

Massa Específica: $2.703 \mathrm{~kg} / \mathrm{m}^{3}$

Porosidade: 1,01\%

Absorção D'água: 0,38 \%

Resistência à Compressão Simples:151,5 MPA

Resistência ao Desgaste Amsler: 0,63 mm

Coeficiente de Dilatação Térmica Linear: $7,1.10^{-3} \mathrm{~mm} / \mathrm{m}^{\circ} \mathrm{C}$

\subsubsection{Jacarandá Rosado (Migmatito Sienogranítico)}

Rocha encontrada no município de Extrema de Minas Gerais (FIGURA 4.6).

\section{Análise Petrográfica}

Sigla Amostra: JR

Natureza da Rocha: Rocha Metamórfica

Classificação Petrográfica: Migmatito Sienogranítico

Nome Comercial: Jacarandá Rosado 


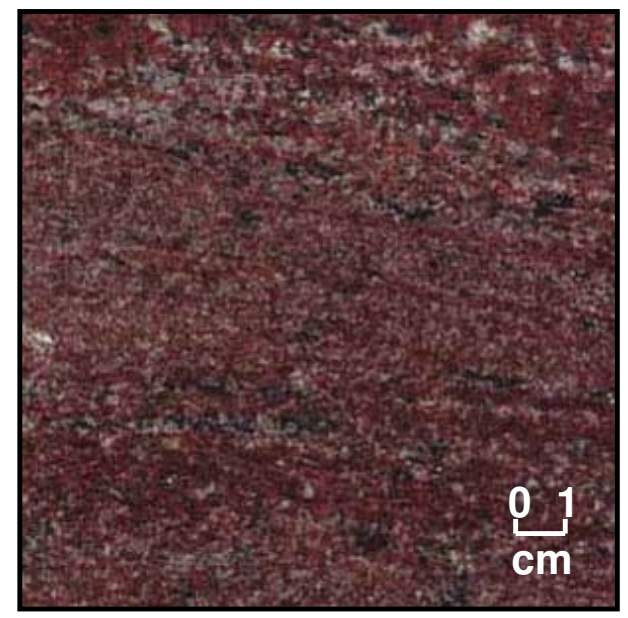

Figura 4.6 - "Granito" Jacarandá Rosado.

\section{Descrição Macroscópica}

Exibe uma coloração rósea acastanhada a acinzentada contendo esparsas pontuações pretas e padrão estético variável, entre o homogêneo e o movimentado (fantasia), definido por típica estrutura migmatítica nebulítica. Este migmatito apresenta grandes variações estruturais e texturais, como é típico nesse tipo de rocha. Em geral há predomínio da estrutura nebulítica, sendo possível o reconhecimento de foliação com planos espaçados, localmente perturbados por dobras, que definem as estruturas migmatíticas do tipo dobrada a flebítica.

A textura é fanerítica, inequigranular com granulação predominantemente média, com gradações localizadas para termos com granulação fina ou para média-grossa. Os contatos minerais são variados, predominando os tipos côncavo-convexos e lobulados, que por vezes tende a contatos planos, ocorrendo localmente minerais com contatos serrilhados.

O microfissuramento moderado a intenso afeta de maneira semelhante todas as espécies minerais e é definido por planos intragrão com e sem comunicação. Fraturas intragranulares são planos pouco extensos que afetam dois ou três cristais, embora não raras. O preenchimento por minerais secundários é comum. O grau de alteração varia de fraco a moderado, sendo ligeiramente mais intenso no plagioclásio que no feldspato. 
Tabela 4.6 - Composição Mineralógica do Jacarandá Rosado

\begin{tabular}{c|c}
\hline Composição Mineralógica & (\% modal) \\
\hline Quartzo & 30,5 \\
Feldspato Potássico (Microclínio) & 38,5 \\
Plagioclásio & 22,0 \\
Biotita $^{*}$ & 8,6 \\
Acessórios $^{*}$ & 0,4 \\
Minerais Secundários $^{\star *}$ & $\mathrm{tr}$ \\
\hline
\end{tabular}

* Acessórios: opacos, granada, zircão, titanita e apatita.

* Minerais Secundários: sericita, epidoto, argilominerais e carbonatos.

\section{Caracterização Tecnológica}

Massa Específica: $2.653 \mathrm{~kg} / \mathrm{m}^{3}$

Porosidade: 0,65\%

Absorção D’água: 0,26 \%

Resistência à Compressão Simples:156,4 MPa

Resistência ao Desgaste Amsler: 0,55 mm

Coeficiente de Dilatação Térmica Linear: $5,41.10^{-3} \mathrm{~mm} / \mathrm{m}^{\circ} \mathrm{C}$

\subsubsection{Preto Indiano (Migmatito com estrutura dobrada)}

Rocha encontrada em Vargem Alta, Espirito Santo (FIGURA 4.7).

\section{Análise Petrográfica}

Sigla Amostra: PI

Natureza da Rocha: Rocha Metamórfica

Classificação Petrográfica: Migmatito com estrutura dobrada

Nome Comercial: Preto Indiano 


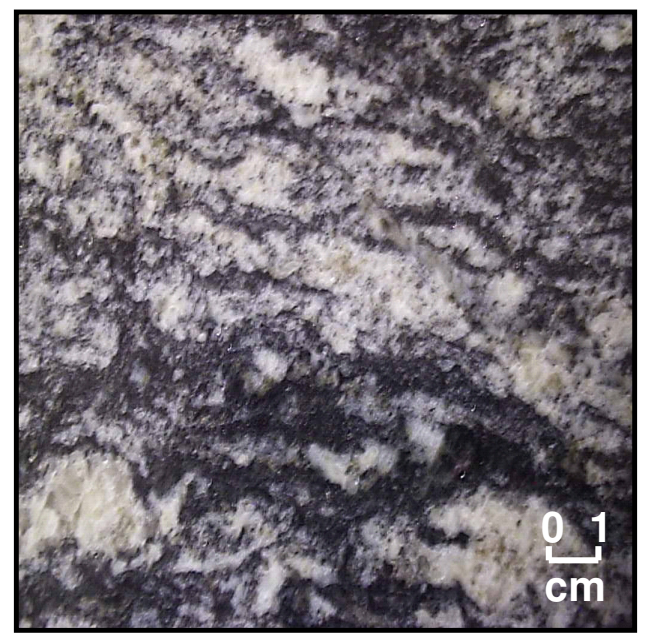

Figura 4.7- "Granito" Preto Indiano.

\section{Descrição Macroscópica}

Exibe diferentes intensidades de gnaissificação, responsável pelo maior e menor grau de paralelismo entre os níveis paleossômicos e leucossômicos. O paleossoma apresenta cor cinza escura, textura granoblástica a granolepidoblástica, de granulação média, predominantemente entre 1,5 e 4,0mm. O leucossoma apresenta cor esbranquiçada, textura granular hipidiomórfica com granulação média (2,0 a $4,0 \mathrm{~mm})$ a média/grossa $(5,0$ a $10,0 \mathrm{~mm})$. Localmente, encontra-se parcialmente envolvido por delgados leitos biotíticos com silimanita e muscovita, de textura lepidoblástica.

Em geral, a rocha exibe baixo microfissuramento e fraca alteração mineral. O microfissuramento intragrãos é mais freqüente nos cristais maiores de feldspatos e de quartzo da porção leucossômica. As microfissuras são de pequena extensão e normalmente preenchidas por sericita e muscovita. A alteração mineral relaciona-se principalmente aos cristais de silimanita, à alguns cristais de plagioclásio (que se encontram de parcial a totalmente saussuritizados nas frações paleossômica e leucossômica). 
Tabela 4.7 - Composição Mineralógica do Preto Indiano - Paleossoma

\begin{tabular}{c|c}
\hline Composição Mineralógica & (\% modal) \\
\hline Quartzo & 22,0 \\
Feldspato Potássico (Microclínio) & 4,5 \\
Andesina/Oligoclásio & 41,0 \\
Biotita & 23,0 \\
Sillimanita & 5,0 \\
Muscovita & 3,0 \\
Granada & 1,0 \\
Cordierita & 0,3 \\
Acessórios & 0,2 \\
Minerais Secundários & $\mathrm{tr}$ \\
\hline
\end{tabular}

*Acessórios: opacos, zircão, carbonatos, sericita e argilo-minerais.

Tabela 4.8 - Composição Mineralógica do Preto Indiano - Leucossoma

\begin{tabular}{c|c}
\hline Composição Mineralógica & (\% modal) \\
\hline Quartzo & 32,0 \\
Feldspato Potássico (Microclínio) & 25,0 \\
Andesina/Oligoclásio & 40,0 \\
Biotita & 3,0 \\
Acessórios $^{*}$ & $\operatorname{tr}$ \\
Minerais Secundários $^{* *}$ & $\operatorname{tr}$ \\
\hline
\end{tabular}

\section{Caracterização Tecnológica}

Massa Específica: $2.770 \mathrm{~kg} / \mathrm{m}^{3}$

Porosidade: $0,98 \%$

Absorção D'água: 0,35 \%

Resistência à Compressão Simples: L: 108,71 MPa (direção perpendicular ao plano de serragem); F: 104,47 MPa (paralela a este plano)

Resistência ao Desgaste Amsler: 1,07 mm

Coeficiente de Dilatação Térmica Linear: S: $8,8 \cdot 10^{-3} \mathrm{~mm} / \mathrm{m}^{\circ} \mathrm{C} 9$ (horizontal na direção paralela ao plano de serragem); $F: 7,13 \cdot 10^{-3} \mathrm{~mm} / \mathrm{m}^{\circ} \mathrm{C}$ (vertical na direção paralela ao plano de serragem) 


\subsubsection{Verde Labrador (Charnockito)}

Extraída no Distrito Baixo Guandu, Município Baixo Guandu, Espírito Santo (FIGURA 4.8)

\section{Análise Petrográfica}

Sigla Amostra: VL

Natureza da Rocha: Rocha Magmática (Plutônica)

Classificação Petrográfica: Charnockito inequigranular discretamente gnaissificado.

Nome Comercial: Verde Labrador

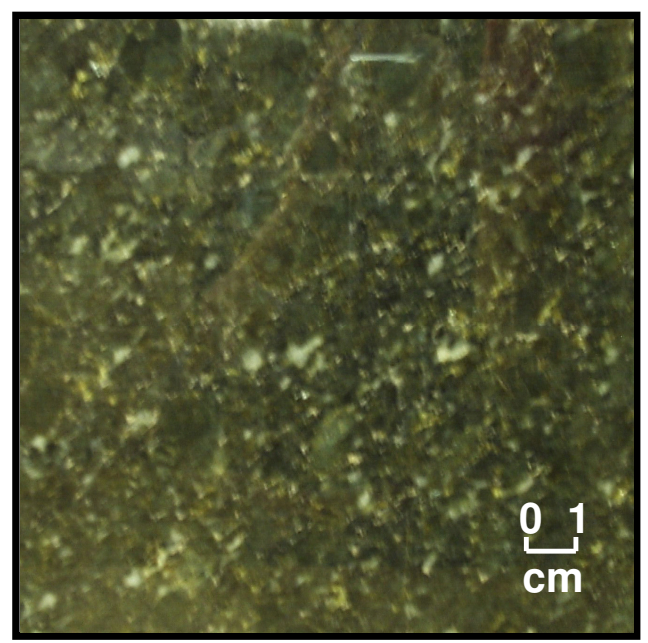

Figura 4.8- "Granito" Verde Labrador.

\section{Descrição Macroscópica}

Charnockito de cor verde garrafa inequigranular a megaporfirítico serial com estrutura discretamente orientada, dada por certo estiramento mineral. O feldspato potássio perfaz cerca de $40 \%$ da rocha e ocorre basicamente como megacristais com formatos subedrais, ovalados ligeiramente alongados, por vezes prismáticos, discretamente isorientados e com dimensões seriadas oscilando entre 1,5 a 4,5 cm, com predominância entre 2,0 e 2,0 cm. A matriz apresenta granulação variável, média a média/grossa, dominantemente entre 2,0 e 8,0 mm. O quartzo manifesta-se sob forma de agregados de grãos anedrais e no conjunto desenvolvem uma 
verdadeira malha ou rede interligada, de aspecto ligeiramente achatado a estirado, que envolve os demais cristais da rocha.

Tabela 4.9 - Composição Mineralógica do Verde Labrador

\begin{tabular}{c|c}
\hline Composição Mineralógica & (\% modal) \\
\hline Quartzo & 29,0 \\
Feldspato Potássico (Ortoclásio) & 43,0 \\
Plagioclásio (Oligoclásio) & 20,5 \\
Biotita & 2,0 \\
Hiperstênio & 1,5 \\
Hornblenda & 0,5 \\
Diopsidio & 2,0 \\
Acessórios (opacos, apatita e zircão) & 1,0 \\
Minerais Secundários (bastita, sericita, & 0,5 \\
epidoto, óxidos e hidróxidos de ferro) &
\end{tabular}

\section{Caracterização Tecnológica}

Massa Específica: $2.677 \mathrm{~kg} / \mathrm{m}^{3}$

Porosidade: $0,24 \%$

Absorção D’água: 0,09 \%

Resistência à Compressão Simples:183,18 MPa

Resistência ao Desgaste Amsler: 0,86 mm

Coeficiente de Dilatação Térmica Linear: $7,3 \cdot 10^{-3} \mathrm{~mm} / \mathrm{m}^{\circ} \mathrm{C}$

\subsubsection{Mármore}

O foco principal da pesquisa ora em desenvolvimento foram as rochas graníticas, que são de uso geral para pisos e revestimentos internos e externos. Entretanto para saber o comportamento do mármore, que é uma rocha de uso restrito por sua baixa resistência às solicitações mecânicas e químicas, foi testado um só tipo, o mais conhecido mundialmente, que é o mármore de Carrara. Especificamente o Carrara Gioia, extraído na região da Toscana, província de Massa-Carrara, Itália (FIGURA 4.9). 


\section{Análise Petrográfica}

Sigla Amostra: MC

Natureza da Rocha: Rocha Carbonática

Classificação Petrográfica: Mármore Calcítico

Nome Comercial: Mármore Carrara

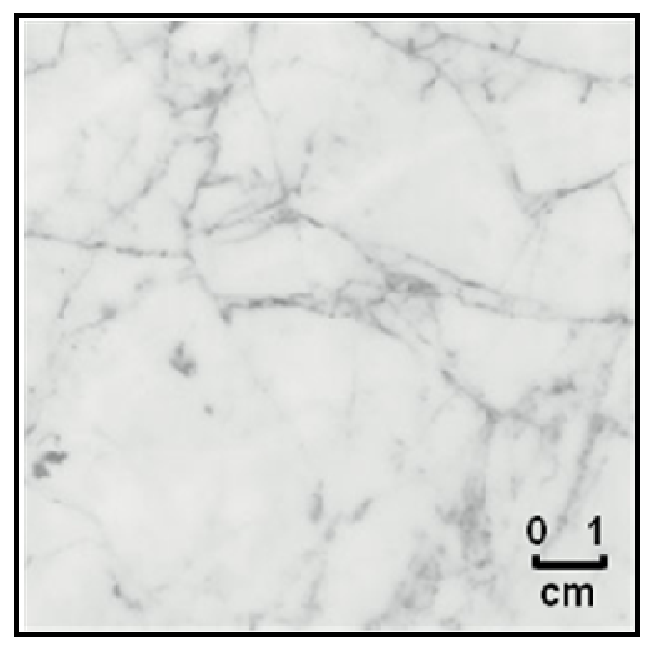

Figura 4.9 - Mármore Carrara.

\section{Descrição Macroscópica}

Rochas constituídas por mais de $90 \%$ de minerais carbonáticos, mais especificamente, calcita e/ou dolomita, formadas a partir do metamorfismo de rochas sedimentares calcíticas e/ou dolomíticas. Apresentam estrutura maciça e granulação variada (fina a grossa). A textura típica é granoblástica e, além de carbonatos, podem conter talco, anfibólio (tremolita), piroxênios (diopsídio), olivina (forsterita) dentre outros.

\section{Caracterização Tecnológica}

Massa Específica: $2.740 \mathrm{~kg} / \mathrm{m}^{3}$

Absorção D'água: 0,31 \%

Resistência à Compressão Simples: 131,4 MPA

Resistência ao Desgaste Amsler: 7,03 mm 


\subsubsection{Principais Minerais das Rochas Estudadas}

Para se ter uma idéia da influência mineralógica na aderência das rochas foram efetuados ensaios, com três tipos de minerais o feldspato (microclínio) e o quartzo principais minerais dos "granitos", e a calcita o principal componente do mármore. Os macrocristais ensaiados foram escolhidos levando em consideração a pureza e a ausência de inclusões.

\subsection{ARGAMASSAS}

No presente trabalho foram comparadas cinco argamassas:

1. Argamassa colante Industrializada para granitos e mármores, aqui referida como Argamassa Industrializada;

2. Argamassa colante desenvolvida para fixação de porcelanato por Almeida (2005), no Laboratório de Construção Civil, aqui referida como Argamassa para porcelanato;

3. Argamassa preparada tendo como base a Argamassa porcelanato, variando a quantidade de água, aqui referida como Arg1;

4. Argamassa preparada tendo como base a Argamassa porcelanato, variando o tipo de cimento, aqui referida como Arg2;

5. Argamassa preparada tendo como base a Argamassa porcelanato, variando quantidade de polímero e água, aqui referida como Arg3.

\subsubsection{Argamassa Industrializada}

É específica para granito e mármore, mas como sua composição não pode ser conhecida foi solicitada uma análise ao Instituto de Pesquisas Tecnológicas (IPT), cujos resultados se encontram nas Tabelas 4.10, 4.11 e 4.12. 
Tabela 4.10 - Resultados da análise química

\begin{tabular}{|c|c|}
\hline Determinações & Resultados(\%) \\
\hline \hline Umidade & 0,2 \\
\hline Perda ao fogo & 30,4 \\
\hline Resíduo insolúvel & 16,5 \\
\hline Anidrido silícico (SiO2) & 3,47 \\
\hline Óxido de ferro e alumínio (R2O3) & 0,99 \\
\hline Óxido de cálcio (CaO) & 36,3 \\
\hline Óxido de magnésio (MgO) & 12,1 \\
\hline Anidrido sulfúrico (SO3) & 0,72 \\
\hline Anidrido carbônico (CO2) & 30,1 \\
\hline
\end{tabular}

A partir destes resultados, foram calculados seus constituintes percentuais, traço e relação aglomerante/agregado, em massa, considerando-se os seguintes parâmetros:

-A fração agregado é constituída por agregado carbonático dolomítico $\left[\mathrm{CaMg}\left(\mathrm{CO}_{3}\right)_{2}\right]$ e calcítico $\left(\mathrm{CaCO}_{3}\right)$ - calculado estequiometricamente a partir do teor total de anidrido carbônico $\left(\mathrm{CO}_{2}\right)$ - e por agregado silicoso - correspondente ao resíduo insolúvel;

- O teor de cimento foi calculado de duas maneiras: a partir do anidrido silícico $\left(\mathrm{SiO}_{2}\right)$ da argamassa - adotando-se como parâmetro de referência um cimento branco com teor de $\mathrm{SiO}_{2}$ de $20,4 \%$ - e por diferença de $100 \%$ em relação ao teor de agregado (calculado como indicado acima).

Tabela 4.11 - Resultados de reconstituição do traço.

\begin{tabular}{|c|c|c|c|}
\hline Parâmetros calculados & Cimento & Agregado & Rel. Aglo/Agre \\
\hline \hline Constituintes (\%) & 18,8 & 81,2 & $1: 4,3$ \\
\hline Traço, em massa & 1 & 4,3 & \\
\hline
\end{tabular}


Tabela 4.12 - Composição granulométrica.

\begin{tabular}{|c|c|c|c|}
\hline \multicolumn{2}{|c|}{ Peneiras } & \multicolumn{2}{c|}{ Material retido (\%) } \\
\hline \hline Designação & Abertura $(\mathrm{mm})$ & Individual & Acumulado \\
\hline \hline $1 / 4$ in & 6,3 & 0 & 0 \\
\hline $\mathrm{n}^{\circ} 04$ & 4,8 & 0 & 0 \\
\hline $\mathrm{n}^{\circ} 08$ & 2,4 & 0 & 0 \\
\hline $\mathrm{n}^{\circ} 6$ & 1,2 & 0 & 0 \\
\hline $\mathrm{n}{ }^{\circ} 0$ & 0,6 & 0 & 0 \\
\hline $\mathrm{n}{ }^{\circ} 0$ & 0,3 & 13 & 13 \\
\hline $\mathrm{n}{ }^{\circ} 00$ & 0,15 & 27 & 40 \\
\hline$<\mathrm{n}{ }^{\circ} 00$ & $<0,15$ & 61 & 100 \\
\hline \multicolumn{2}{|l}{ Totais } & 101 & 100 \\
\hline Módulo de finura & & 0,52 \\
\hline Dimensão máxima característica $(\mathrm{mm})$ & & 0,6 \\
\hline
\end{tabular}

\subsubsection{Argamassa porcelanato}

Desenvolvida para assentamento de porcelanato, por Almeida (2005) e escolhida para ser usada na presente pesquisa porque o porcelanato e 0 granito possuem uma característica em comum, a baixíssima porosidade $(<3 \%)$, que restringe a aderência "mecânica" (por ancoragem), sendo ela eletroquímica.

Segundo Almeida (op. cit.) o mecanismo de aderência entre a argamassa e o porcelanato é o resultado de forças entre filme polimérico e compostos hidratados (ligação secundária de van der Waals), aderência por interação física. A melhora da aderência é promovida pela rugosidade da superfície que está em contato (tardoz) com a argamassa.

Sua composição é: $5 \%$ de sílica, $20 \%$ de látex, relação at $/ c=0,4$ (at - água total, incluindo a água proveniente do látex polimérico), a proporção cimento:areia é 1:1,5 em massa e $1 \%$ de superplastificante em relação à massa do cimento.

\subsubsection{Argamassas preparadas tendo como base a argamassa para porcelanato}

A tabela 4.13 mostra seis tipos de argamassa preparados, tendo como base a composição da argamassa para porcelanato, delas três foram rejeitadas por não possuírem trabalhabilidade, 
Tabela 4.13 - Argamassas preparadas tendo como base a composição da argamassa para porcelanato.

\begin{tabular}{|c|c|c|c|}
\hline Combinação & Nome & Variação & Aspecto \\
\hline 1 & Arg1 & Redução de água de 0,4 para 0,25 & Boa fluidez \\
\hline 2 & Arg2 & $\begin{array}{c}\text { Substituição do cimento Ari por cimento } \\
\text { branco }\end{array}$ & boa fluidez \\
\hline 3 & Arg3 & $\begin{array}{c}\text { dobra a quantidade de polimero e reduz a } \\
\text { quantidade de água de 0,4 para 0,3 }\end{array}$ & boa fluidez \\
\hline 4 & $*$ & traço de 1:1,5 para 1:2 & seca (farofa) \\
\hline 5 & $*$ & Quantidade de silica de 5\% para 10\% & ressecada \\
\hline 6 & $*$ & dobra a quantidade de polimero & Muita fluida \\
\hline
\end{tabular}

Obs: as argamassas com * foram rejeitadas por falta de trabalhabilidade.

\section{a) Arg1}

Foi preparada diminuindo a relação água/cimento de 0,4 para 0,25 , devido à alta fluidez da argamassa porcelanato.

\section{b) Arg2}

Substituindo na mesma proporção o cimento ARI- Cimento de alta resistência inicial pelo cimento branco. Isto porque foi verificado que o cimento ARI em contato com a rocha provoca manchamento.

\section{c) Arg3}

Foi preparada dobrando a quantidade de polímero para aumentar a flexibilidade e devido a alta fluidez da argamassa porcelanato foi diminuída a relação água/cimento de 0,4 para 0,3 . 


\section{5 - PROCEDIMENTOS DOS ENSAIOS}

Os ensaios realizados constaram de: nas rochas e minerais - medidas de rugosidade; nas argamassas - tempo em aberto, flexibilidade e deslizamento; No conjunto substrato padrão/argamassa/rocha - aderência, microsestrutura, ataque químico e congelamento/degelo.

\subsection{MEDIDA DA RUGOSIDADE DAS ROCHAS E DOS MINERAIS}

\section{Nas rochas}

Adotou-se o perfilômetro portátil, projetado e construído por PARAGUASSÚ et. al (2004), aprimorado por RIBEIRO et. al (2005), mostrado na Figura 5.1, especifico para placas de rochas graníticas serradas em teares, que determina o perfil de rugosidade e se obtém o parâmetro de rugosidade Rt.

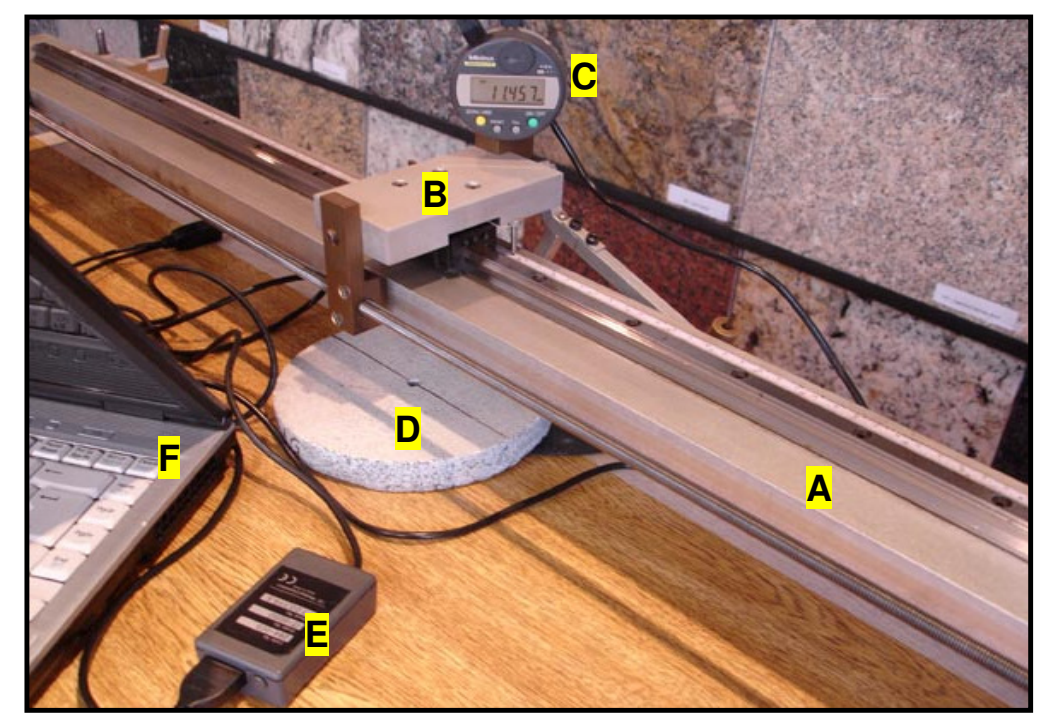

Figura 5.1 - Detalhe do "Avaliador de Rugosidade de Chapas - ARC", PARAGUASSÚ et. al. (2.004): (A) corpo do equipamento; (B) carro de medição; (C) defletômetro digital com precisão de $0,001 \mathrm{~mm}$.; (D) placa de rocha; (E) interface que envia as medidas do defletômetro para o computador $(\mathrm{F})$.

O parâmetro de rugosidade (Rt) corresponde à maior distância entre pico-vale (altura que o material teria que ser desgastado no polimento) ao longo do comprimento avaliado (FIGURA 5.2). 


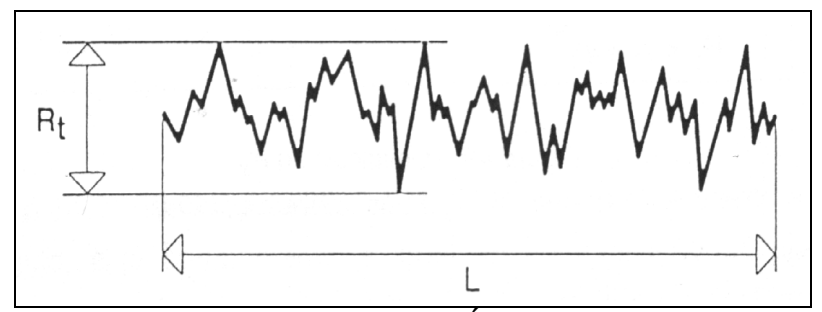

Figura 5.2 - Definição de $\mathrm{R}_{\mathrm{t}}$ (SANDVIK, 1994 apud SPÍNOLA, 1998).

\section{Nos minerais}

Macrocristais de feldspato (microclínio, amostra "A" e microclínio de cor avermelhada, amostra "B"), quartzo e calcita, relativamente puros e com poucas inclusões foram serrados na forma de placas com dimensões de $3 \times 4 \mathrm{~cm} e$ espessura de $1 \mathrm{~cm}$. As irregularidades do processo de serragem foram retiradas por desbaste em politriz com utilização de abrasivo 220 mesh para eliminar a influência da rugosidade na aderência. Figuras 5.3 à 5.6.

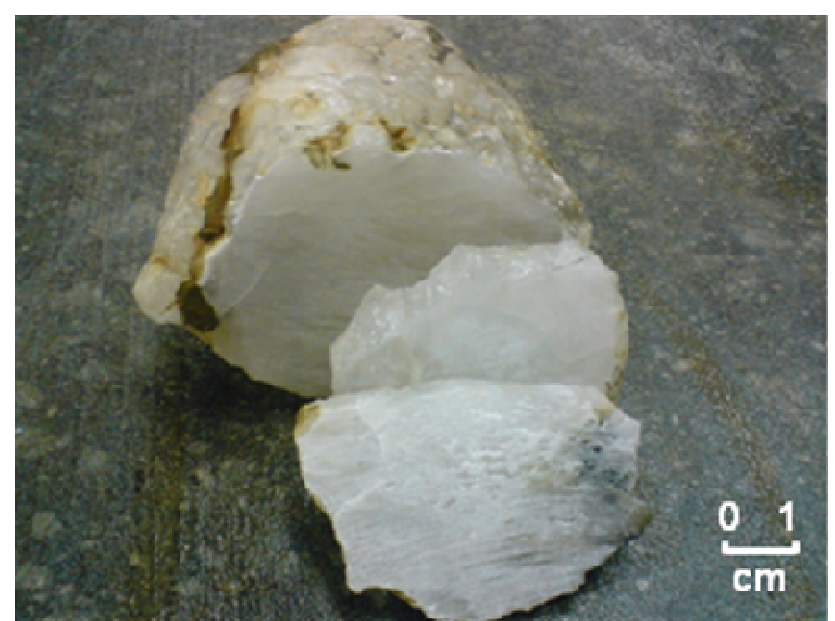

Figura 5.3 - Preparação dos corpos-de-prova de quartzo. 


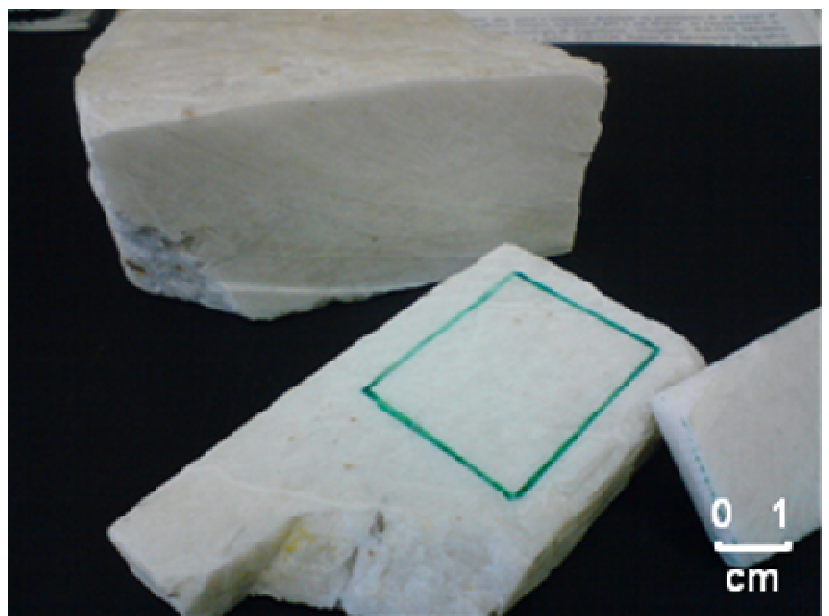

Figura 5.4 - Preparação dos corpos-de-prova (corpo-de-prova desenhado em verde) do microclinio.

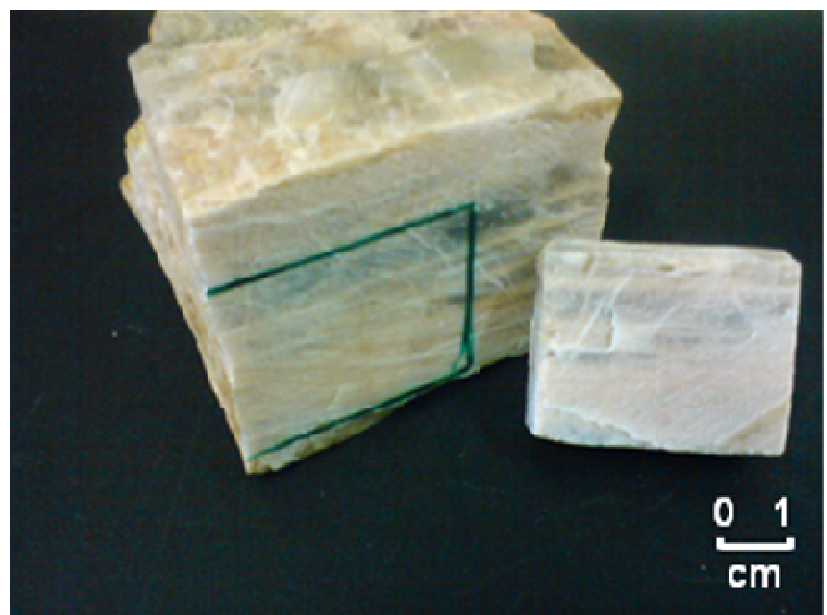

Figura 5.5 - Preparação dos corpos-de-prova do feldspato microclinio, corpo-de-prova pronto.

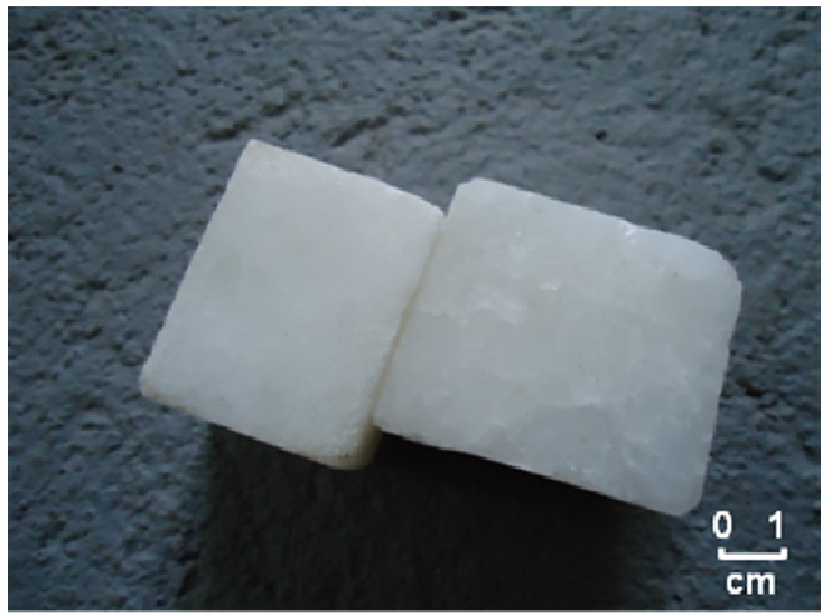

Figura 5.6 - Preparação dos corpos-de-prova da calcita, corpo-de-prova pronto. 
Devido a baixíssima rugosidade (ordem de $\mu \mathrm{m}$ ) apresentadas pelas superfícies polidas dos minerais foi medida com o rugosímetro de contato modelo Talysurf 1205 , (FIGURA 5.7).

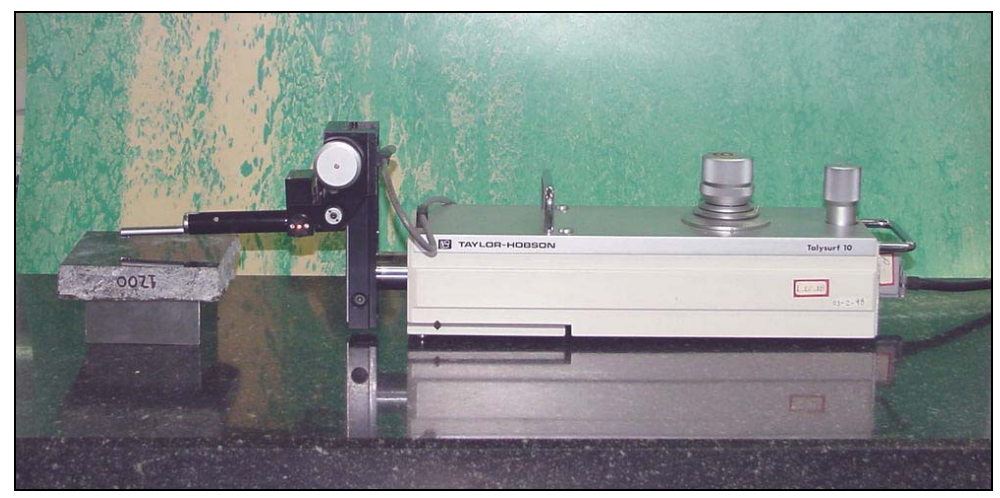

Figura 5.7 - Rugosímetro de contato modelo Talysurf 1205.

Foi determinada a média aritmética da rugosidade $\mathrm{Ra}$, que é o parâmetro mais utilizado, refletindo a média dos valores absolutos de todas as ordenadas do perfil, dentro do comprimento de avaliação. Isto equivale à altura de um retângulo de comprimento L e cuja área representa o somatório das áreas fechadas entre o perfil da rugosidade e a linha média. Em geral, o comprimento utilizado para se obter $\mathrm{R}_{\mathrm{a}}$ inclui cinco conjuntos de picos-vales sucessivos, representado na Figura 5.8 pela letra M.

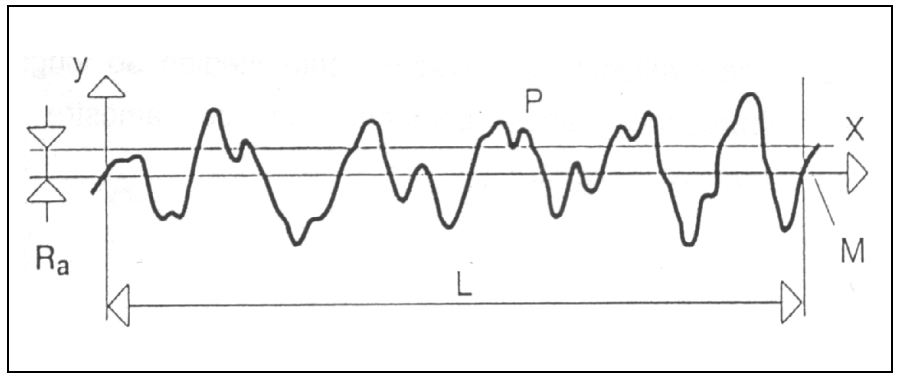

Figura 5.8 - Definição de $R_{\mathrm{a}}$ (SANDVIK, 1994 apud SPÍNOLA, 1998).

\subsection{DETERMINAÇÃO DO TEMPO EM ABERTO}

Foi feito segundo os procedimentos descritos na NBR 14083 (ABNT, 2004c). Como é uma propriedade da argamassa o ensaio foi realizado com um só tipo de 
rocha, o Amarelo Ornamental (Granada Gnaisse Porfiroblástico) escolhido aleatoriamente.

\subsection{DETERMINAÇÃO DA FLEXIBILIDADE DA ARGAMASSA}

Utilizou-se a norma internacional ISO 13007-2 (International Organization for Standardization). Os corpos-de-prova de todos os tipos de argamassa com dimensões de $280 \times 45 \mathrm{~mm}$ e espessura de $3 \mathrm{~mm}$, foram avaliados após 30 e 60 dias de moldagem.

O cálculo da resistência à flexão foi feito pela norma ASTM C 580 (1993), segundo a expressão:

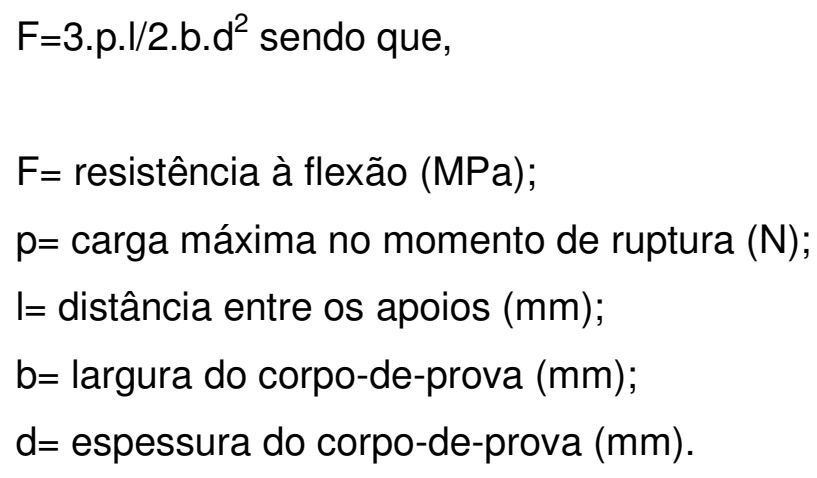

\subsection{DETERMINAÇÃO DO DESLIZAMENTO}

Foi executado segundo a norma NBR 14085 (desenvolvida originalmente para ensaios com material cerâmicos) com adaptação para rochas substituindo as peças cerâmicas por peças de $10 \mathrm{~cm} \times 10 \mathrm{~cm}$ do granito Preto São Gabriel (rocha mais pesada das estudadas). A argamassa colante foi estendida sobre um substrato padrão e nela as placas de rocha foram assentadas. Após o assentamento este conjunto foi posicionado na vertical e observou-se quanto a placa de rocha deslizou após 20 minutos. O resultado de deslizamento deve atender as especificações da norma $(\leq 0,5 \mathrm{~mm})$. 


\subsection{ENSAIO DE RESISTÊNCIA DE ADERÊNCIA À TRAÇÃO}

\subsubsection{Confecção do substrato padrão}

Ele foi moldado conforme os procedimentos prescritos na NBR 14082/2004b.

\subsubsection{Preparação dos corpos de prova}

\section{- De rocha}

A extração dos corpos-de-prova das rochas (discos com diâmetro de 3,0 cm) foi feita em ladrilhos utilizando furadeira de coluna com broca diamantada. Os discos possuem duas faces paralelas, uma polida e a outra com a rugosidade (estrias) resultante do processo de serragem nos teares.

Os ensaios de aderência foram executados em duas etapas:

a) Corpos-de-prova aderidos à argamassa pela superfície rugosa;

b) Corpos-de-prova aderidos à argamassa pela superfície "polida". Previamente o brilho foi retirado em torno mecânico com retífica de rebolo diamantado, deixando todos os corpos de prova com mesma rugosidade, próxima de zero, em ordem de $\mu \mathrm{m}$. As medidas da rugosidade foram feitas com o Talysurf 1205.

\section{- De minerais}

Corpos-de-prova foram extraídos de macro cristais de feldspato (microclínio), quartzo e calcita, com dimensões de $3 \times 4$ e $1 \mathrm{~cm}$ de espessura. Uma das superfícies foi desbastada em politriz com abrasivo 220 mesh para eliminar a influência da rugosidade na aderência (rugosidade próxima de zero).

\subsubsection{Determinação da resistência de aderência ao arrancamento por tração}

A aplicação das argamassas na superfície do substrato foi feita de acordo com a norma NBR 14082 (ABNT, 2004b) e o ensaio de arrancamento à tração foi feito, após 28 dias, seguiu os procedimentos descritos na NBR 14084 (ABNT, 2004d). 


\subsection{MICROESTRUTURA DA INTERFACE ROCHA/ARGAMASSA}

Do conjunto substrato padrão/argamassa/rocha foram preparadas secções delgadas perpendiculares, para serem observadas ao microscópio óptico de transmissão. O objetivo foi verificar, se na interface da rocha/argamassa ocorreu aderência por ancoragem, reação química e se existe bolhas de ar entre a rocha e a argamassa. Como esperado houve dificuldades na confecção das lâminas por se tratar de 3 materias com diferentes resistências ao corte com disco diamantado (concreto/argamassa/"granito") mas, após varias tentativas em que a argamassa ou o substrato trincou e perdendo amostras o problema foi resolvido, cortando com velocidades diferentes cada material e deixando na espessura máxima necessária para observação ao microscópio óptico com luz transmitida.

\subsection{ATAQUE QUÍMICO}

Foram extraídos 1.080 corpos-de-prova retangulares $(3 \times 4 \mathrm{~cm})$ dos oito tipos de "granitos" e do mármore como mostrado na tabela 5.1, fixados no substrato padrão com as cinco argamassas estudadas segundo a NBR 14082 (ABNT, 2004b) e submetidos aos ataques: ácido, básico e com detergente.

Tabela 5.1 -Quantidade de corpos-de-prova.

\begin{tabular}{|c|c|c|c|}
\hline Rocha & Ataque ácido & Ataque básico & Detergente \\
\hline \hline Marmore Carrara & 40 & 40 & 40 \\
\hline Cinza Andorinha & 40 & 40 & 40 \\
\hline Amarelo Ornamental & 40 & 40 & 40 \\
\hline Vermelho Brasília & 40 & 40 & 40 \\
\hline Preto São Gabriel & 40 & 40 & 40 \\
\hline Verde Labrador & 40 & 40 & 40 \\
\hline Azul Fantástico & 40 & 40 & 40 \\
\hline Preto Indiano & 40 & 40 & 40 \\
\hline Jacaranda Rosado & 40 & 40 & 40 \\
\hline \multicolumn{2}{|r|}{} & Total & 1080 \\
\cline { 2 - 4 }
\end{tabular}


Como as normas brasileiras não contemplam o ataque químico especificamente para rochas ornamentais, foram utilizadas somente 3 das soluções preconizada pela NBR 13818/1997 (Placas cerâmicas para revestimento - Especificação e métodos de ensaios.- Determinação da resistência ao ataque químico) as soluções ácida, básica e com detergente como mostrada na tabela 5.2 .

Tabela 5.2 - Substâncias químicas e suas respectivas concentrações utilizadas no ataque químico.

\begin{tabular}{|c|c|}
\hline Substância & Concentração \\
\hline \hline ÁcidoCloridrico $(\mathrm{HCl})$ & $18 \%(\mathrm{~V} / \mathrm{V})$ \\
\hline Hidroxido de Potássio $(\mathrm{KOH})$ & $100 \mathrm{~g} / \mathrm{l}$ \\
\hline Detergente & $20 \%(\mathrm{~V} / \mathrm{V})$ \\
\hline
\end{tabular}

O ataque foi feito por borrifamento dessas soluções sobre o sistema: rocha, argamassa e substrato padrão, depois esperou-se seis horas para a secagem ao ar, contemplando assim um ciclo de ataque químico. Após 50 ciclos foram feitos ensaios de resistência de aderência.

O objetivo foi quantificar a variação da resistência de aderência ao final do ensaio.

\subsection{ENSAIO DE CONGELAMENTO E DEGELO}

É uma simulação que integra o grupo dos ensaios de durabilidade. Cada ciclo é constituído por 6 horas de imersão em água a temperaturas positivas (degelo), retirado da água e 6 horas, a temperaturas abaixo dos $0^{\circ} \mathrm{C}$ (congelamento). Neste estádio, a água que penetrou nas fissuras e nos poros abertos irá congelar aumentando de volume, fenômeno que com o decurso dos ciclos poderá provocar alteração estrutural da rocha (fissuração, desagregação, etc.) e, conseqüentemente, inaptidão ao seu desempenho em obra. É, pois, um ensaio fundamental sempre que se pretenda utilizar uma rocha em aplicações exteriores nas regiões com clima que inclua períodos regulares com temperaturas negativas.

Foram feitas algumas adaptações ao ensaio convencional por se tratar de um sistema: rocha+argamassa+substrato-padrão e não está sendo analisada somente a aparência e as características da rocha, mas também sua aderência com a argamassa. Sendo assim os corpos-de-prova das rochas foram fixados num 
substrato padrão e imersos em água por 30 min. Após esse tempo, o conjunto foi retirado da água e colocado em um freezer a temperatura de $-5^{\circ} \mathrm{C}$ por 6 horas (congelamento). Decorrido este tempo foi imerso em água à temperatura ambiente por 6 horas (degelo), completando um ciclo de congelamento/degelo. Após 50 ciclos foram realizados ensaios de resistência de aderência à tração nos corpos-de-prova. 


\section{6 - RESULTADOS DOS ENSAIOS}

Serão apresentados os resultados dos oito ensaios realizados, nos quais foram preparados um total de 3.096 corpos-de-prova dentre: rochas, minerais e argamassa e descartado cerca de 900 corpos-de-prova que apresentaram problemas durante os ensaios.

\subsection{ASPECTOS APRESENTADOS PELAS ARGAMASSAS}

Além da argamassa industrializada foram realizados ensaios com a argamassa para porcelanato e mais três argamassas diferentes, dela derivadas, já que ela em estudos anteriores havia apresentado características excelentes para fixação de placas de rochas de revestimentos.

\subsection{DETERMINAÇÃO DO TEMPO EM ABERTO}

A Figura 6.1. mostra somente os resultados de aderência das argamassas desenvolvidas em laboratório porque a argamassa industrializada apresenta seu tempo em aberto descrito na embalagem (20 min) e como este ensaio é uma propriedade da argamassa, foi executado aleatoriamente para um único tipo de rocha o Amarelo Ornamental. Todas as argamassas se encontram dentro da norma ( $\geq 20 \mathrm{~min}$ ) e dentre elas a Arg3 apresentou menor aderência depois de 30 min.

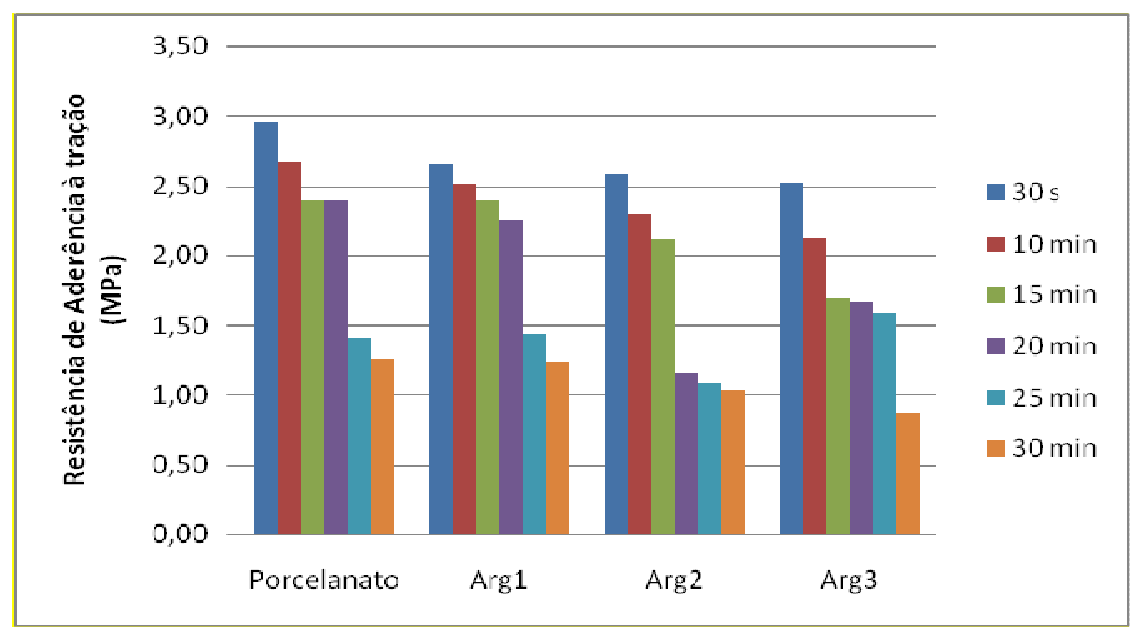

Figura 6.1 - Resistência de aderência com corpos-de-prova fixados depois de $30 \mathrm{~s}, 10 \mathrm{~min}, 15 \mathrm{~min}$, 20 min, 25 min, 30 min para as argamassas para porcelanato, Arg1, Arg2 e Arg3. 


\subsection{DETERMINAÇÃO DA FLEXIBILIDADE}

No ensaio de resistência à flexão os corpos-de-prova feitos com argamassa colante industrializada quebraram ao serem desenformados, inviabilizando o ensaio com essa argamassa pela sua resistência muito baixa à flexão. As Figuras 6.2. a 6.4 mostram os resultados do ensaio de resistência a flexão em 3 pontos (deformação transversal, resistência à flexão e fator F)

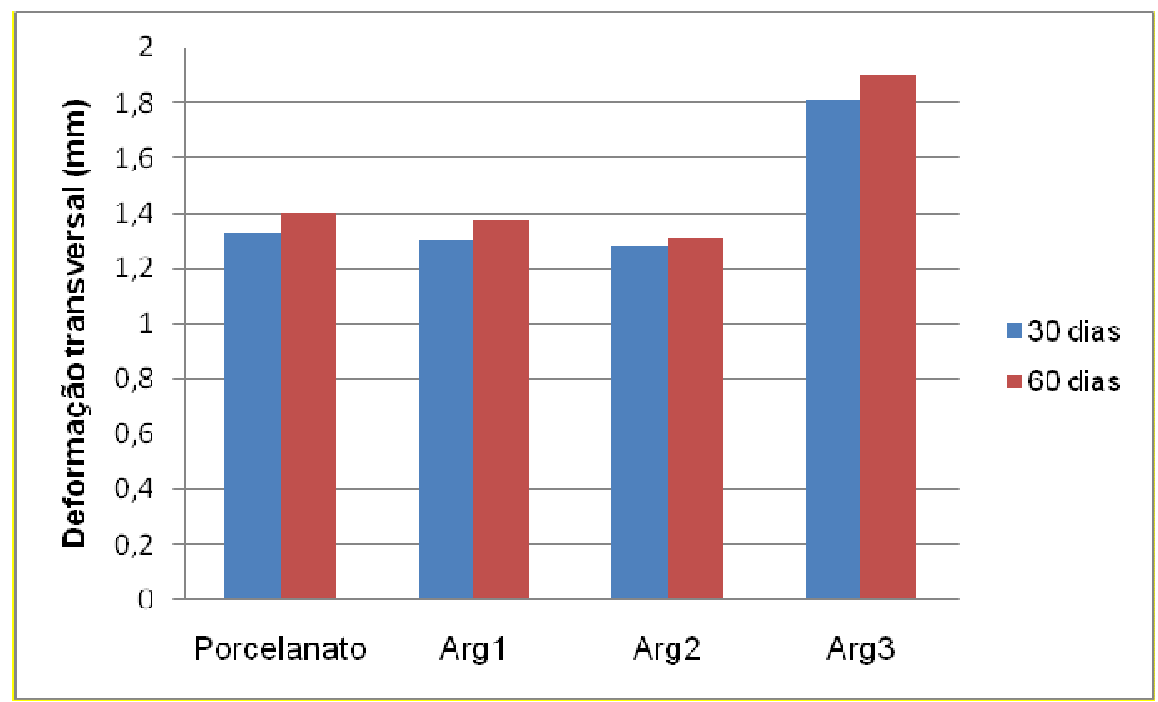

Figura 6.2 - Deformação transversal das argamassas.

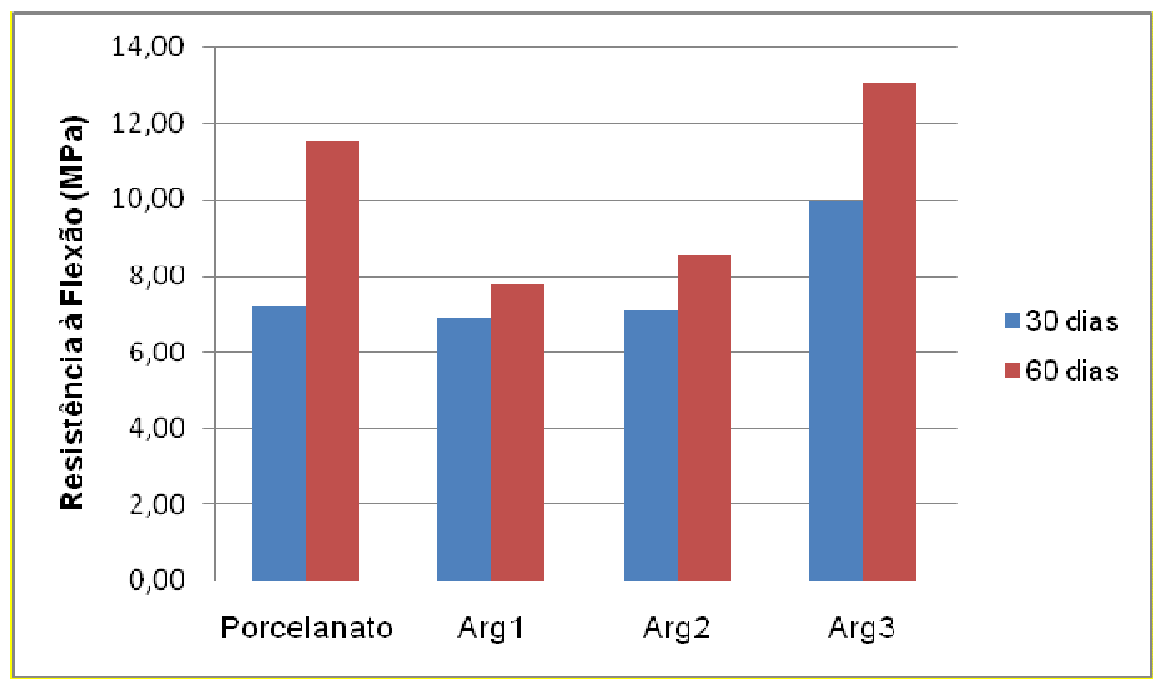

Figura 6.3 - Resistência à flexão das argamassas. 


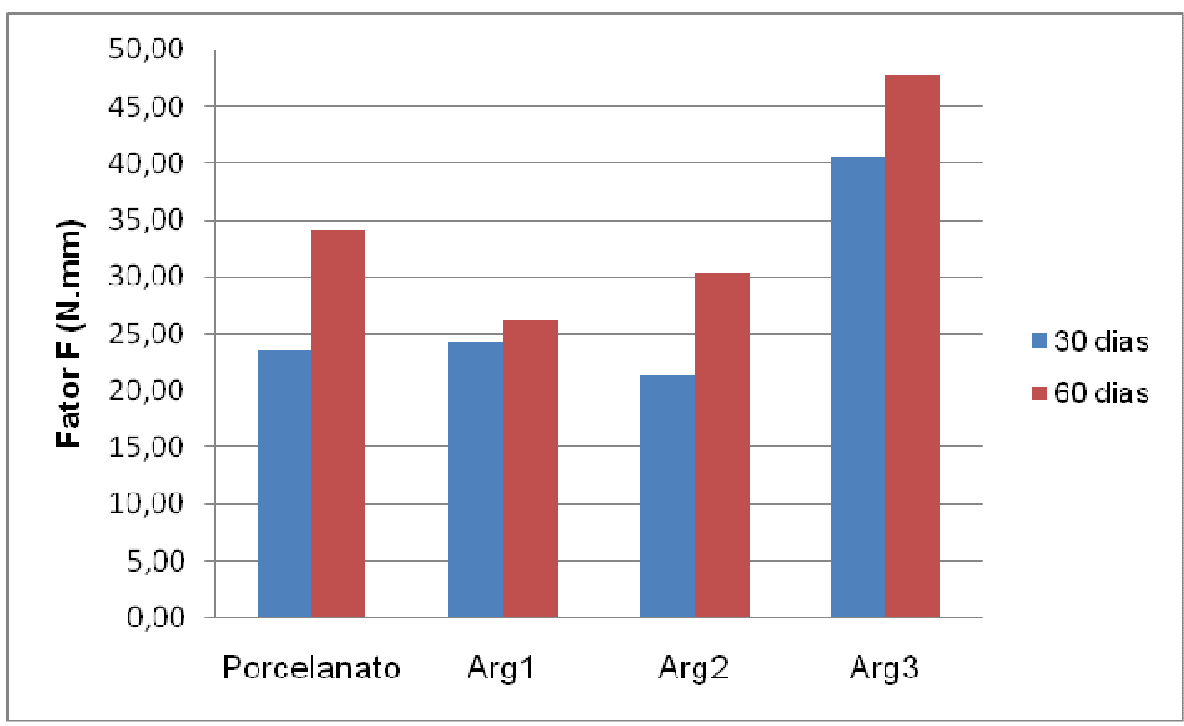

Figura 6.4 - Fator $\mathbf{F}$ resultante do produto entre a força e deslocamento transversal.

Como esperado o aumento da quantidade de polímero (Arg 3 - dobro de polímero que as outras argamassas) influenciou significativamente o desempenho da argamassa quanto à deformação e resistência à flexão.

Observando as Figuras 6.2 a 6.4 vemos que:

- As argamassas apresentaram incremento na capacidade de deformação após 60 dias.

- Todas as argamassas apresentaram incremento na resistência à flexão após 60 dias de moldagem.

- Todas as argamassas apresentaram incremento no Fator F após 60 dias.

A argamassa de melhor desempenho foi a Arg3 em relação às outras, que após 60 dias apresentou valores superior de deformação, de resistência à flexão e de Fator F.

\subsection{DETERMINAÇÃO DO DESLIZAMENTO}

Todas essas argamassas atenderam as especificações da norma ( $\leq 0,5 \mathrm{~mm})$, sendo que a para porcelanato apresentou o maior deslizamento porque é mais fluida, como mostrado na tabela 6.1 . 
Tabela 6.1 - Resultados do ensaio de deslizamento

\begin{tabular}{|c|c|c|c|c|c|c|c|}
\hline \multirow{3}{*}{ Argamassa } & \multicolumn{7}{|c|}{ Deslizamento (mm) } \\
\hline & \multicolumn{5}{|c|}{ Rocha - Preto São Gabriel } & \multirow{2}{*}{$\begin{array}{l}\text { Média } \\
(\mathrm{mm})\end{array}$} & \multirow{2}{*}{$\begin{array}{c}\text { Desvio } \\
\text { padrão } \\
(\mathrm{mm})\end{array}$} \\
\hline & \multicolumn{2}{|c|}{1} & \multicolumn{2}{|c|}{2} & 3 & & \\
\hline \multirow{2}{*}{$\begin{array}{c}\text { Arg. } \\
\text { Porcelanato } \\
\end{array}$} & 0,4 & 0,3 & 0,4 & 0,3 & $0,6 \quad 0,5$ & \multirow{2}{*}{0,42} & \multirow{2}{*}{0,13} \\
\hline & \multicolumn{2}{|c|}{0,35} & \multicolumn{2}{|c|}{0,35} & 0,55 & & \\
\hline \multirow{2}{*}{ Arg. A1 } & 0,1 & 0,2 & 0,2 & 0,2 & \begin{tabular}{l|l}
0,0 & 0,1 \\
\end{tabular} & \multirow{2}{*}{0,13} & \multirow{2}{*}{0,08} \\
\hline & \multicolumn{2}{|c|}{0,15} & \multicolumn{2}{|c|}{0,2} & 0,05 & & \\
\hline \multirow{2}{*}{ Arg. A2 } & 0,3 & 0,2 & 0,1 & 0,2 & \begin{tabular}{l|l}
0,1 & 0,1 \\
\end{tabular} & \multirow{2}{*}{0,17} & \multirow{2}{*}{0,08} \\
\hline & \multicolumn{2}{|c|}{0,25} & \multicolumn{2}{|c|}{0,15} & 0,1 & & \\
\hline \multirow{2}{*}{ Arg. A3 } & 0,2 & 0,3 & 0,1 & 0,3 & \begin{tabular}{l|l}
0,0 & 0,2 \\
\end{tabular} & \multirow{2}{*}{0,18} & \multirow{2}{*}{0,12} \\
\hline & \multicolumn{2}{|c|}{0,25} & \multicolumn{2}{|c|}{0,2} & 0,1 & & \\
\hline
\end{tabular}

\subsection{RESISTÊNCIA DE ADERÊNCIA}

Os ensaios de resistência à aderência à tração foram feitos em duas etapas: a) em corpos-de-prova aderidos à argamassa pela superfície rugosa e b) em corposde-prova aderidos à argamassa pela superfície polida (o brilho foi retirado em torno mecânico com retífica de rebolo diamantado para todas as rochas ficarem com mesma rugosidade, próxima de zero).

a) Resistências médias de aderência à tração das rochas ensaiadas com a face rugosa em contato com as argamassas (Tabela 6.2):

Os valores de resistência de aderência de todas as argamassas estão dentro da norma ( $1 \mathrm{MPa})$. A de melhor aderência foi a argamassa para porcelanato menos para o mármore, no entanto devido a dificuldade de manuseio e por ter muita água podem causar manchamento nas rochas. Deve ser ressaltado que a argamassa industrializada apresentou, para todas as rochas, menores valores de aderência (FIGURA 6.5). 
Tabela 6.2 -Resistência de aderência média das argamassas (entre 8 corpos-de-prova) para todas as rochas estudadas com a face rugosa em contato com as argamassas.

\begin{tabular}{|c|c|c|c|c|c|}
\hline Rochas & $\begin{array}{c}\text { Res. } \\
\text { Aderência } \\
\text { Ind(MPa) }\end{array}$ & $\begin{array}{c}\text { Res. Aderência } \\
\text { para } \\
\text { porcelanato(MPa) }\end{array}$ & $\begin{array}{c}\text { Res. } \\
\text { Aderência } \\
\text { Arg1 } \\
(\mathrm{MPa})\end{array}$ & $\begin{array}{c}\text { Res. } \\
\text { Aderência } \\
\text { Arg2 (MPa) }\end{array}$ & $\begin{array}{c}\text { Res. } \\
\text { Aderência } \\
\text { Arg3 (Mpa) }\end{array}$ \\
\hline Mármore Carrara Gioia & 2,73 & 3,95 & 3,42 & 3,54 & 4,05 \\
\hline Cinza Andorinha & 1,96 & 3,08 & 3,23 & 2,72 & 2,76 \\
\hline Amarelo Ornamental & 1,92 & 2,95 & 2,65 & 2,58 & 2,52 \\
\hline Vermelho Brasília & 1,65 & 2,85 & 2,40 & 2,52 & 2,39 \\
\hline Preto São Gabriel & 1,60 & 2,66 & 2,30 & 2,40 & 2,34 \\
\hline Verde Labrador & 1,55 & 2,65 & 2,20 & 2,20 & 2,13 \\
\hline Azul Fantástico & 1,51 & 2,52 & 2,08 & 2,19 & 2,01 \\
\hline Preto Indiano & 1,50 & 2,51 & 1,86 & 2,16 & 2,00 \\
\hline Jacaranda Rosado & 1,44 & 2,14 & 1,74 & 1,74 & 1,76 \\
\hline
\end{tabular}

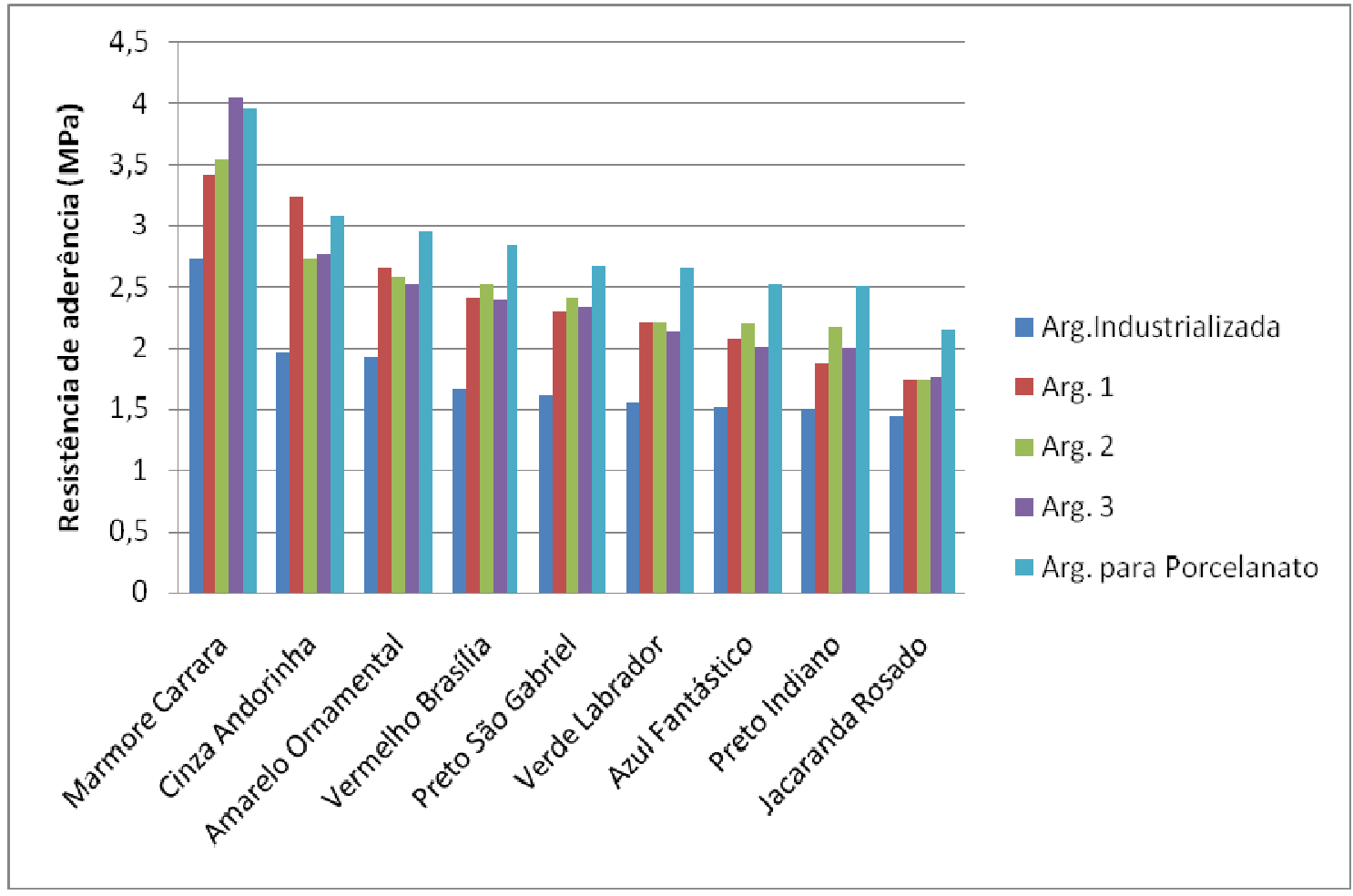

Figura 6.5 - Resistência de aderência para cada argamassa com todas as rochas estudadas.

b) Resistências médias de aderência à tração das rochas ensaiadas com a face polida em contato com as argamassas (Tabela 6.3):

Os valores de resistência de aderência de quase todas as argamassas estão dentro da norma (1MPa) menos da Arg. Industrializada quando retirada a influência da rugosidade. A de melhor aderência continuou sendo a argamassa 
para porcelanato menos para o mármore. No entanto as aderências das rochas não continuaram as mesmas, mostrando que há influência da rugosidade na aderência. Foi possível notar também que quanto maior a quantidade de quartzo na amostra menos aderência ela possui (FIGURA 6.6).

Tabela 6.3 -Resistência de aderência média das argamassas (entre 8 corpos-de-prova) para todas as rochas estudadas com a face polida em contato com a argamassa.

\begin{tabular}{|c|c|c|c|c|c|}
\hline $\begin{array}{c}\text { Res. } \\
\text { Rochas }\end{array}$ & $\begin{array}{c}\text { Res. } \\
\text { Aderência } \\
\text { Ind (MPa) }\end{array}$ & $\begin{array}{c}\text { Res. } \\
\text { Arg1 (MPa) }\end{array}$ & $\begin{array}{c}\text { Res. } \\
\text { Aderência } \\
\text { Arg2 (MPa) }\end{array}$ & $\begin{array}{c}\text { Reres. Aderência } \\
\text { Arg3 (MPa) }\end{array}$ & $\begin{array}{c}\text { para } \\
\text { porcelanato(MPa) }\end{array}$ \\
\hline $\begin{array}{c}\text { Mármore Carrara } \\
\text { Gioia }\end{array}$ & 2,7 & 3,4 & 3,44 & 4 & 3,92 \\
\hline Preto São Gabriel & 0,9 & 2,3 & 2,4 & 2,25 & 2,6 \\
\hline Verde Labrador & 0,8 & 2,2 & 2,25 & 2,18 & 2,55 \\
\hline Preto Indiano & 0,6 & 2,15 & 2,24 & 2,14 & 2,27 \\
\hline Azul Fantástico & 0,57 & 2,1 & 2,18 & 2,1 & 2,22 \\
\hline Cinza Andorinha & 0,55 & 2,05 & 2,1 & 2,03 & 2,15 \\
\hline $\begin{array}{c}\text { Amarelo } \\
\text { Ornamental }\end{array}$ & 0,54 & 1,7 & 1,97 & 1,96 & 2,05 \\
\hline Jacaranda Rosado & 0,54 & 1,6 & 1,83 & 1,75 & 2 \\
\hline Vermelho Brasília & 0,54 & 1,45 & 1,47 & 1,5 & 1,51 \\
\hline
\end{tabular}




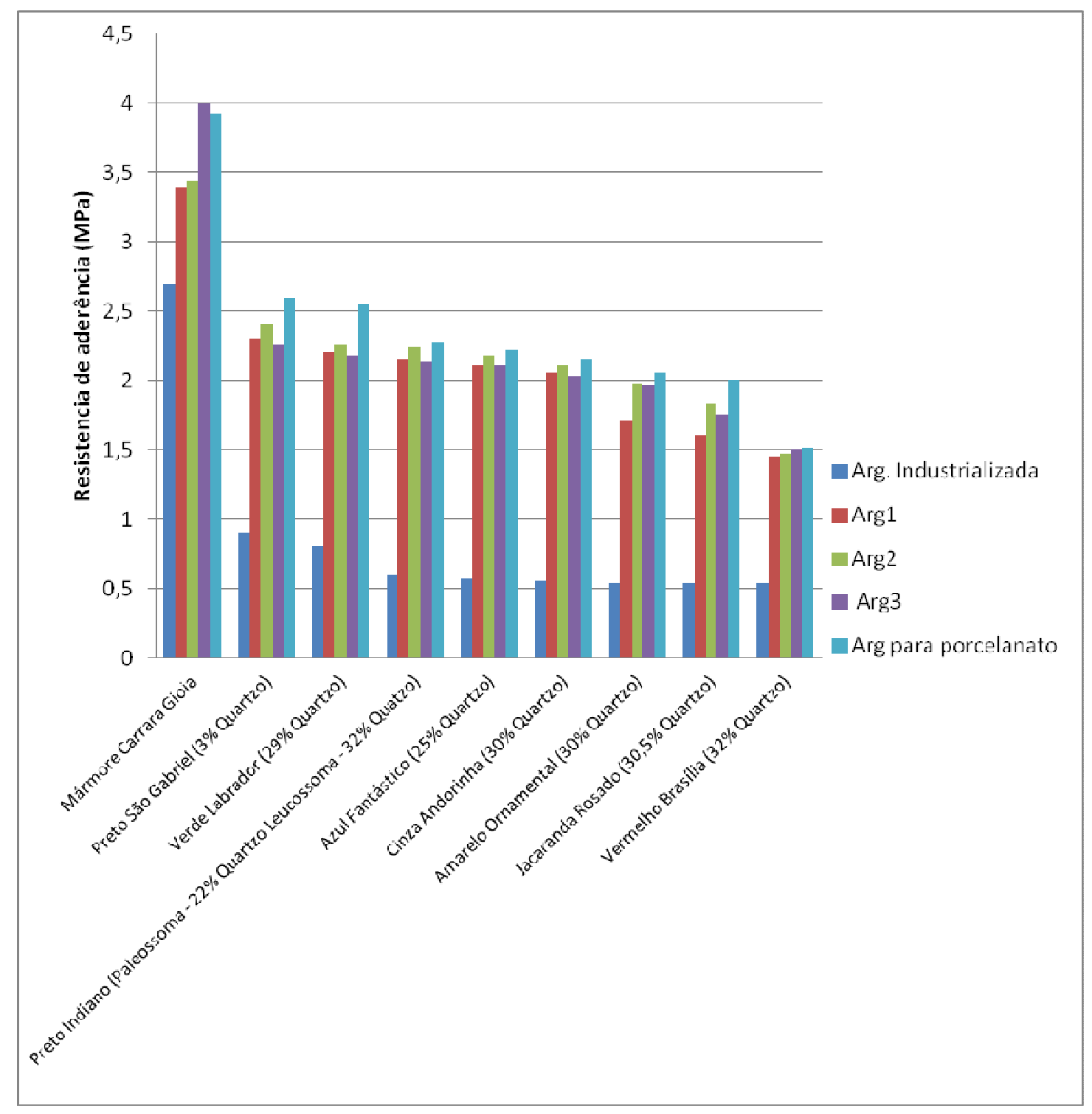

Figura 6.6 - Resistência de aderência para cada argamassa com todas as rochas estudadas.

As Figuras a seguir apresentadas (6.7 a 6.11) mostram os valores de rugosidade de cada corpo-de-prova com sua resistência de aderência para todos os granitos estudados. Na Figura 6.12 encontram-se os valores de rugosidade e resistência de aderência do Mármore Carrara Gioia. 


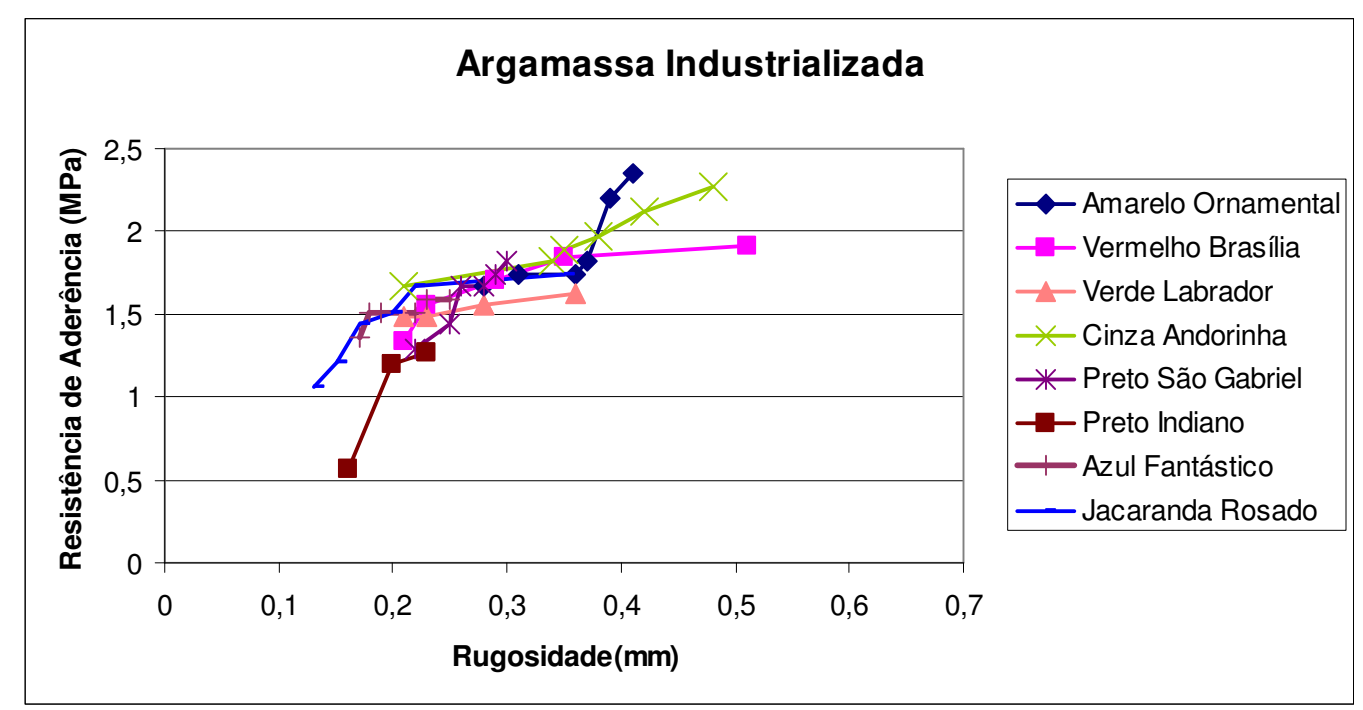

Figura 6.7 - Resistência de Aderência vs. Rugosidade para a Argamassa Industrializada.

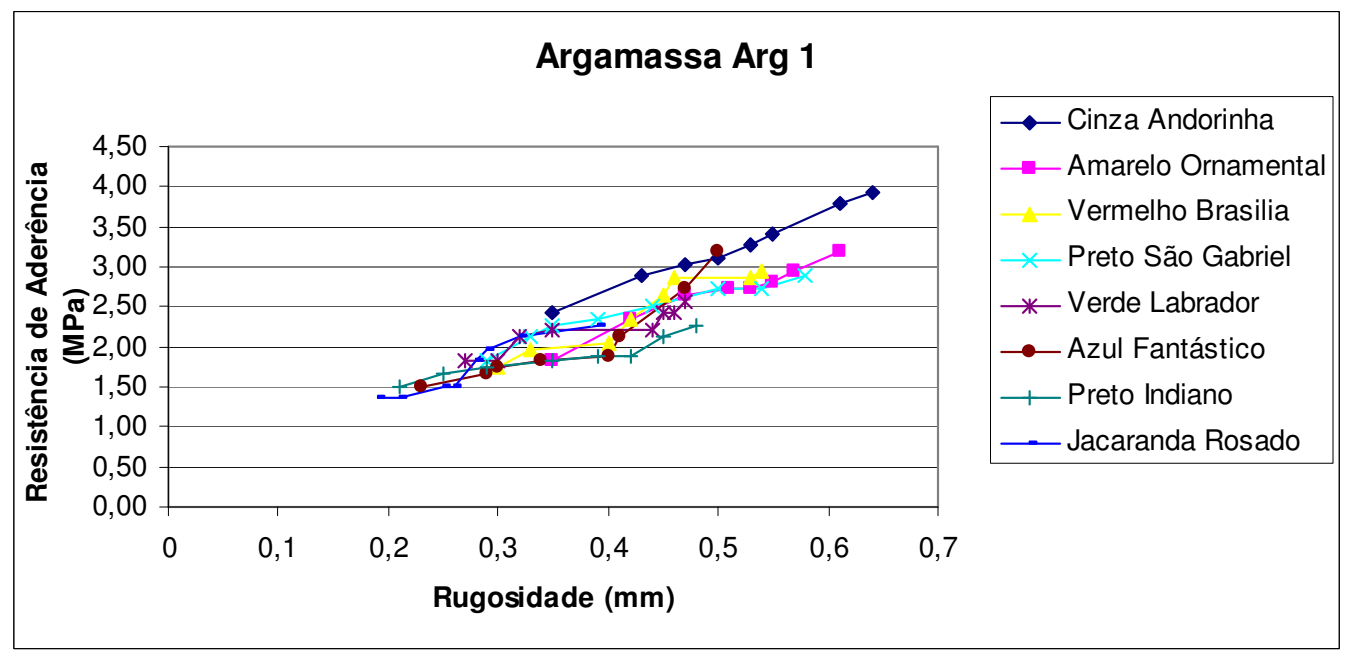

Figura 6.8 - Resistência de Aderência vs. Rugosidade para a Argamassa Arg1. 


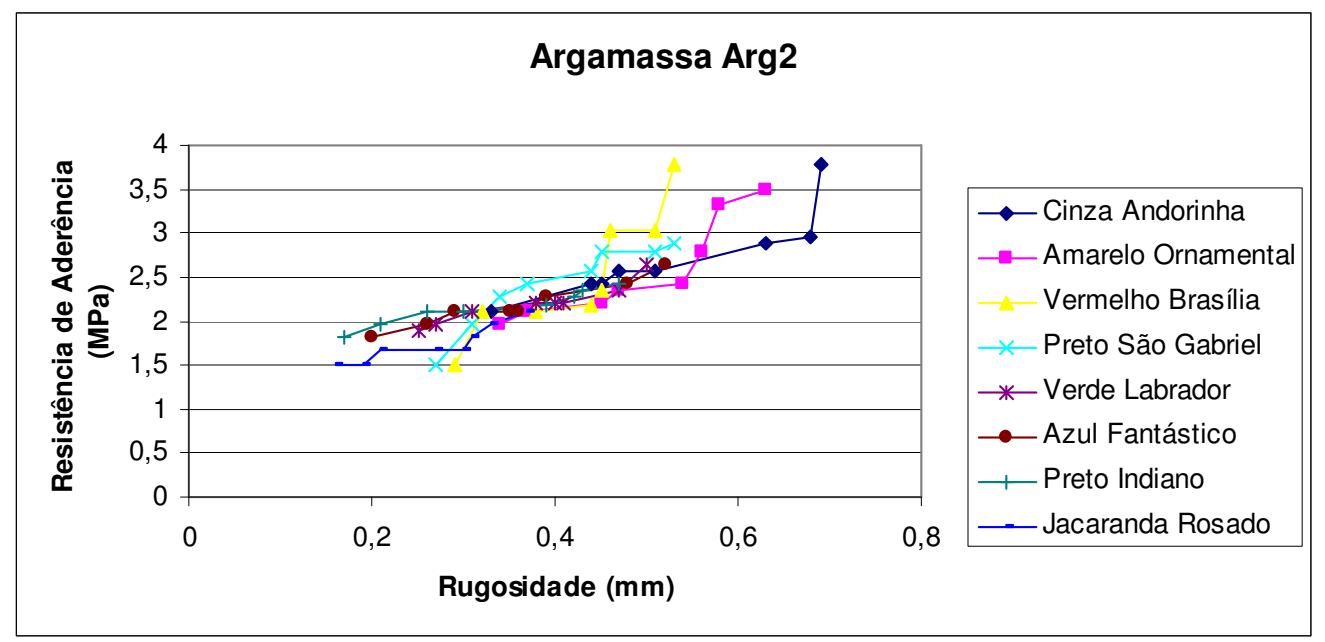

Figura 6.9 - Resistência de Aderência vs. Rugosidade para a Arg2.

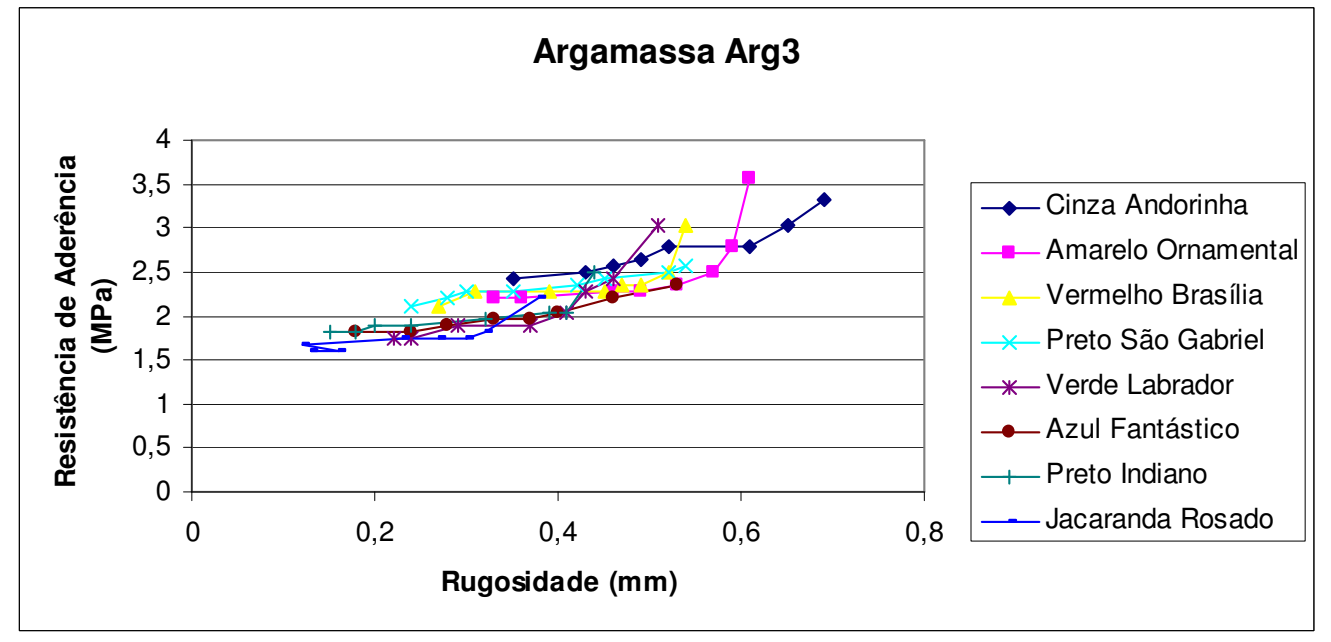

Figura 6.10 - Resistência de Aderência vs. Rugosidade para a Arg3.

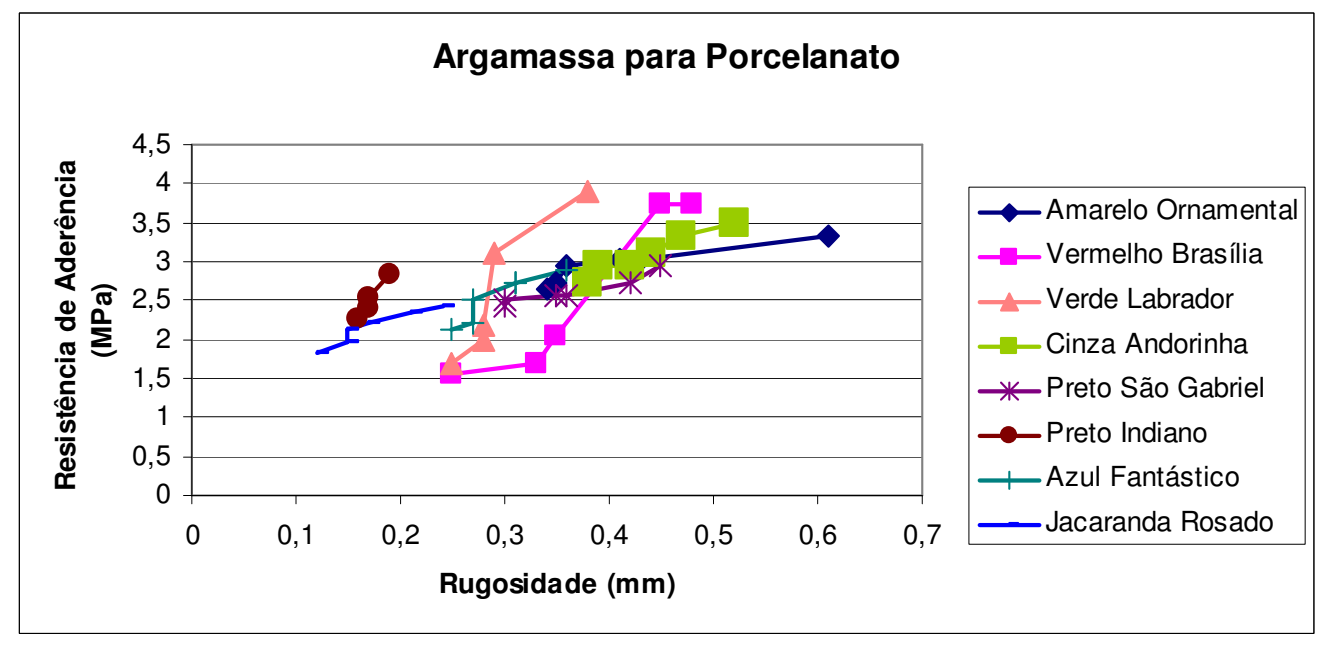

Figura 6.11 - Resistência de Aderência vs. Rugosidade para a argamassa para porcelanato. 
Todos "granitos" tiveram o mesmo comportamento, quanto maior o Rt maior a aderência, mostrando que não houve ancoragem, ela está diretamente ligada à rugosidade e por consequência diretamente correlacionada à área da superfície de contato do corpo-de-prova. É, portanto um fenômeno eletroquímico (forças de Van der Walls) que ocorre na superfície de contato.

Por outro lado, no caso do mármore estudado (FIGURA 6.12), a resistência de aderência deve ser pouco influenciada pela rugosidade (área da superfície de contato) e pela porosidade que é muito baixa (ancoragem) restando, portanto, o mecanismo de aderência por interação química para explicar os altos valores encontrados.

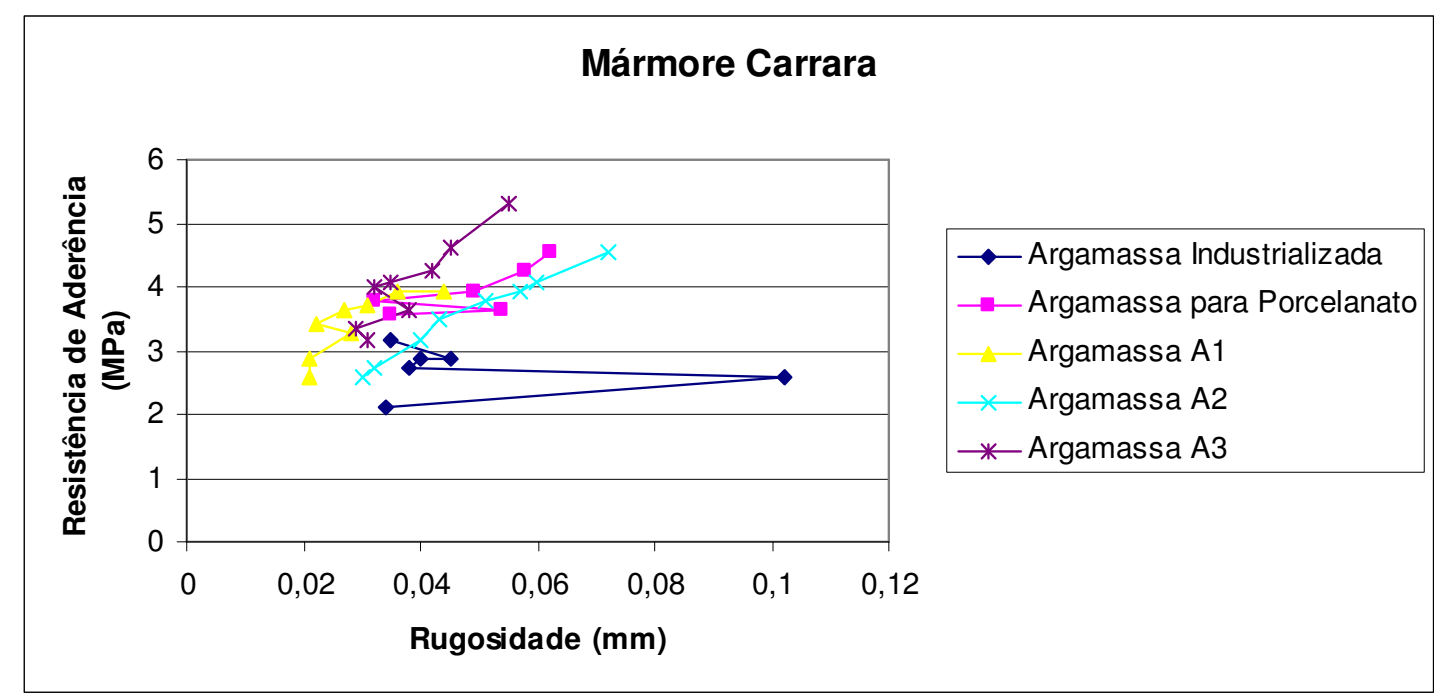

Figura 6.12 - Resistência de Aderência vs. Rugosidade para o Mármore Carrara.

Ensaios realizados com monocristais dos principais minerais das rochas estudadas: feldspato (microclínio), quartzo e calcita foram feitos com a argamassa para porcelanato, por ser a argamassa base para as outras argamassas desenvolvidas em laboratório e também pelo numero limitado de corpos-de-prova disponível de cada mineral. Os resultados mostraram que a resistência de aderência à tração do mineral quartzo é em torno de $50 \%$ da verificada para o feldspato e da calcita é em torno de $150 \%$ quando comparada com o feldspato (TABELA 6.4). 
Tabela 6.4 - Aderência dos minerais

\begin{tabular}{|c|c|}
\cline { 2 - 2 } \multicolumn{1}{c|}{} & $\begin{array}{c}\text { Tensão } \\
(\mathrm{MPa})\end{array}$ \\
\hline QUARTZO & 1,86 \\
\hline FELDSPATO/MICROCLÍNIO A & 2,42 \\
\hline FELDSPATO/MICROCLÍNIO B & 2,41 \\
\hline FELDSPATO/MICROCLÍNIO (avermelhada) A & 2,91 \\
\hline FELDSPATO/MICROCLÍNIO (avermelhada) B & 2,96 \\
\hline CALCITA & 3,59 \\
\hline
\end{tabular}

\subsection{MICROESTRUTURA DA INTERFACE ROCHA/ARGAMASSA}

O exame das lâminas mostrou contatos nítidos entre as placas das rochas e a argamassa, não havendo borda de reação e nem penetração da argamassa na rocha (FIGURAS 6.13 a 6.15). A ancoragem apenas se processou no contato substrato padrão/argamassa (FIGURA 6.16). As fotos apresentadas foram obtidas em microscópio óptico sem o auxílio de luz polarizada.

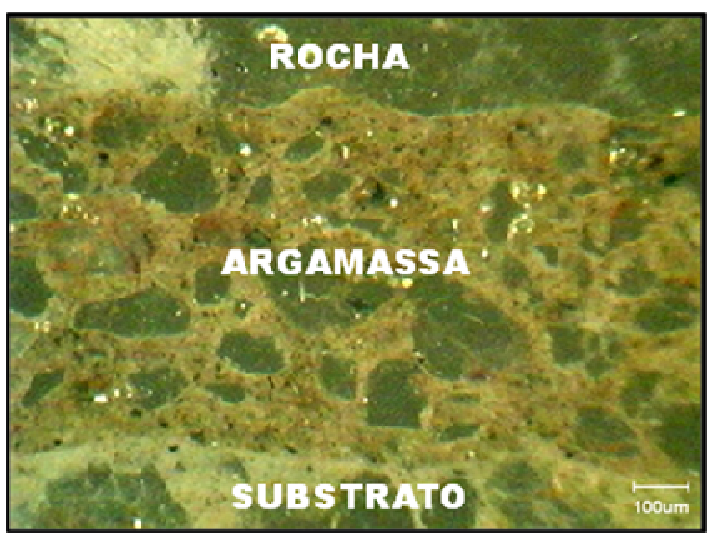

Figura 6.13 - Conjunto Substrato Padrão/Argamassa Colante/Rocha.

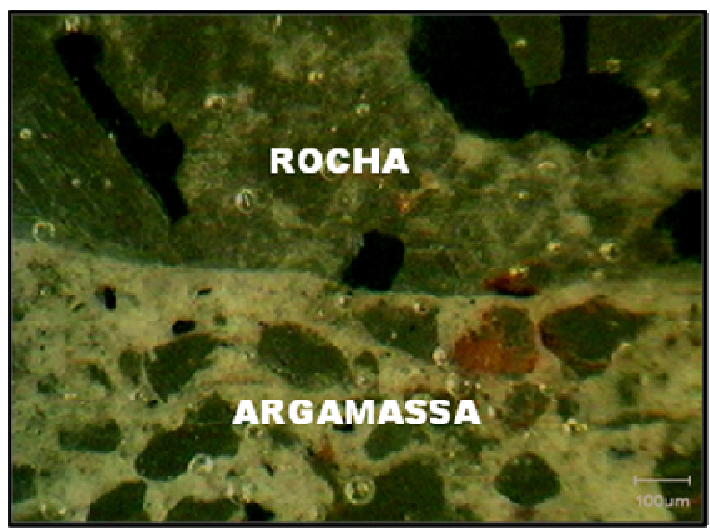

Figura $6.15-$ Contato nítido rocha/argamassa sem borda de reação.

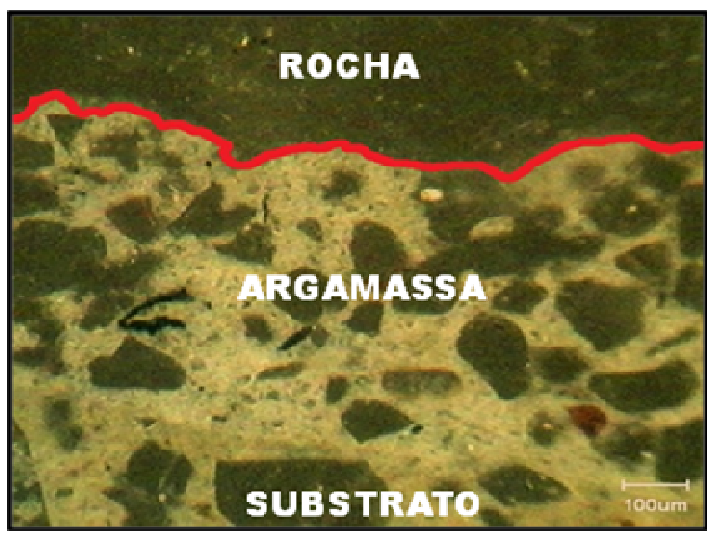

Figura 6.14 - Rugosidade (marcada em vermelho) apresentada pela rocha na interface rocha/argamassa.

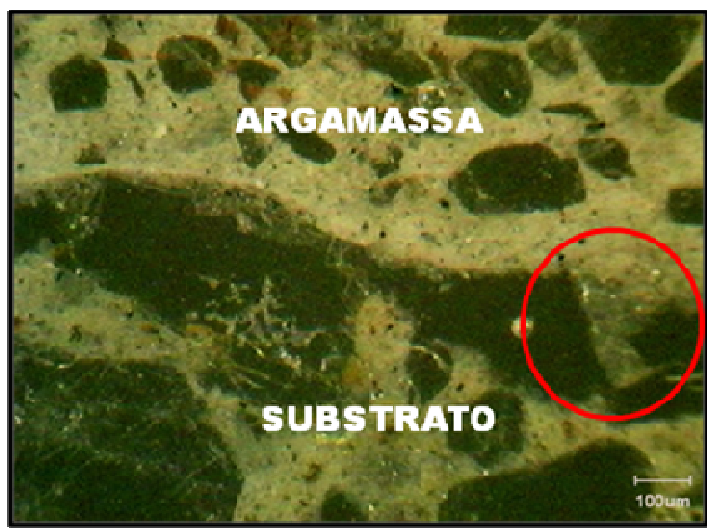

Figura 6.16 - Ancoragem na interface substrato padrão/argamassa. 


\subsection{ATAQUE QUÍMICO}

$\mathrm{O}$ ataque químico nos corpos-de-prova dos "granitos", por borrifamento de soluções ácidas, básicas e de detergente alteraram as rochas a tal ponto que não permitiu a execução dos ensaios de resistência de aderência. As rochas romperam superficialmente ficando as superfícies que estava em contato com a argamassa ainda aderidas.

Isto se explica devido à baixa porosidade dos "granitos" que sofreram uma "exfoliação" superficial, não permitindo o acesso das soluções até a argamassa.

Fenômeno semelhante ocorre em rochas graníticas expostas ao ataque intempérico que se "exfoliam" superficialmente tendo seu interior preservado. Por outro lado, no caso de placas de quartzitos permeáveis é comumente observado desplacamentos ocasionados pelas soluções que penetram atingindo a argamassa e reagindo com os carbonatos.

\subsection{CONGELAMENTO E DEGELO}

No ensaio de resistência ao congelamento/degelo os mármores apresentaram valores superiores a $1 \mathrm{MPa}$ para todas argamassas estudadas (figuras 6.17 a 6.22), no entanto, para os "granitos", somente a argamassa industrializada não atingiu o valor estipulado por norma como mostrado na figura 6.17 .

A argamassa que menos sofreu o efeito do congelamento/gelo foi à preparada com cimento branco (Arg2), com um decréscimo em sua resistência de aproximadamente 10\% (FIGURA 6.19) 


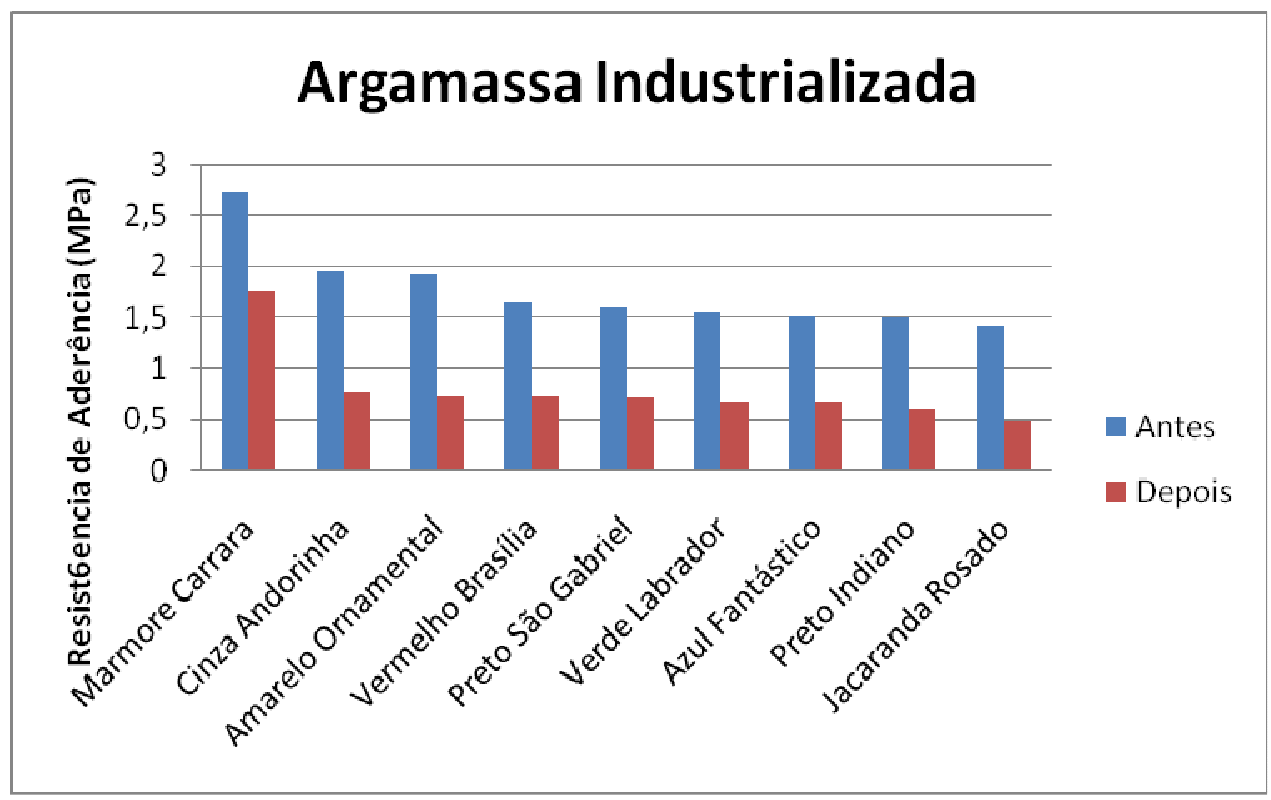

Figura 6.17 - Resistência de aderência da argamassa Industrializada antes e depois do ensaio de congelamento/degelo.

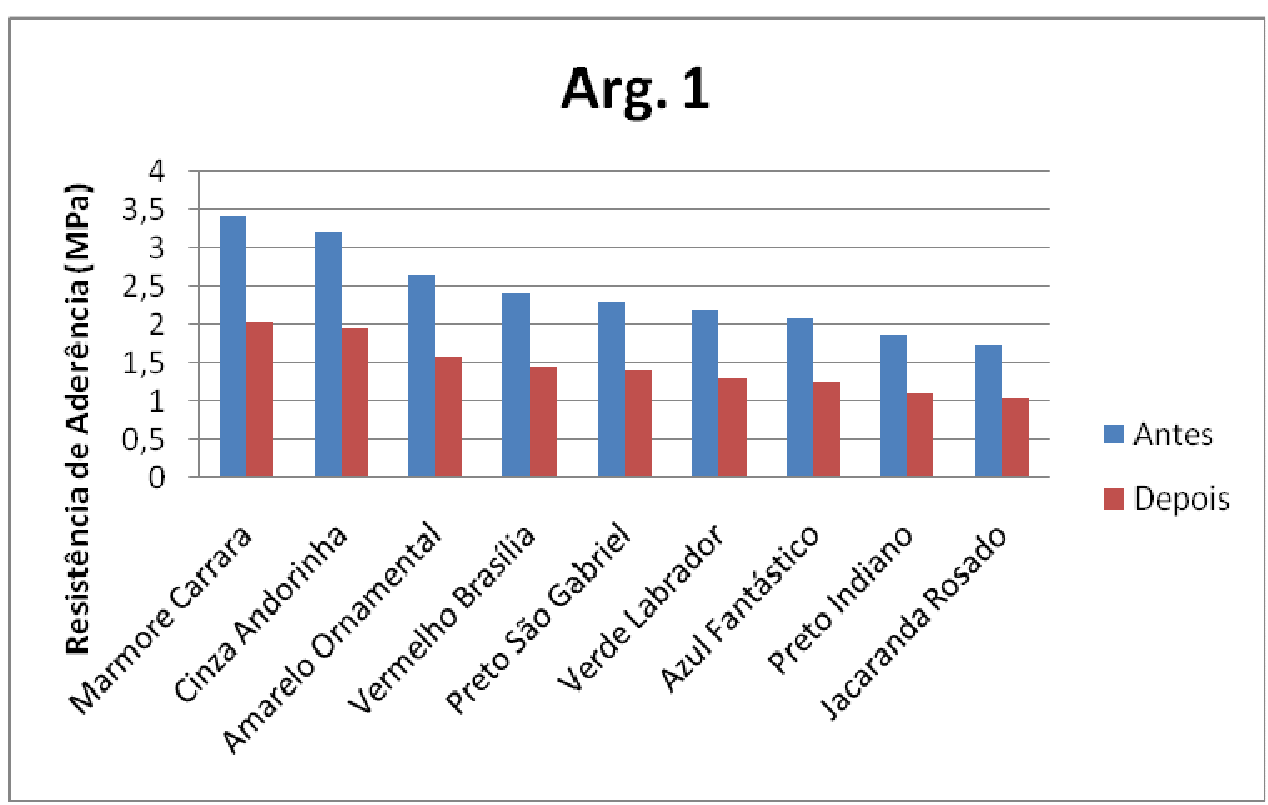

Figura 6.18 - Resistência de aderência da Arg1 antes e depois do ensaio de congelamento/degelo. 


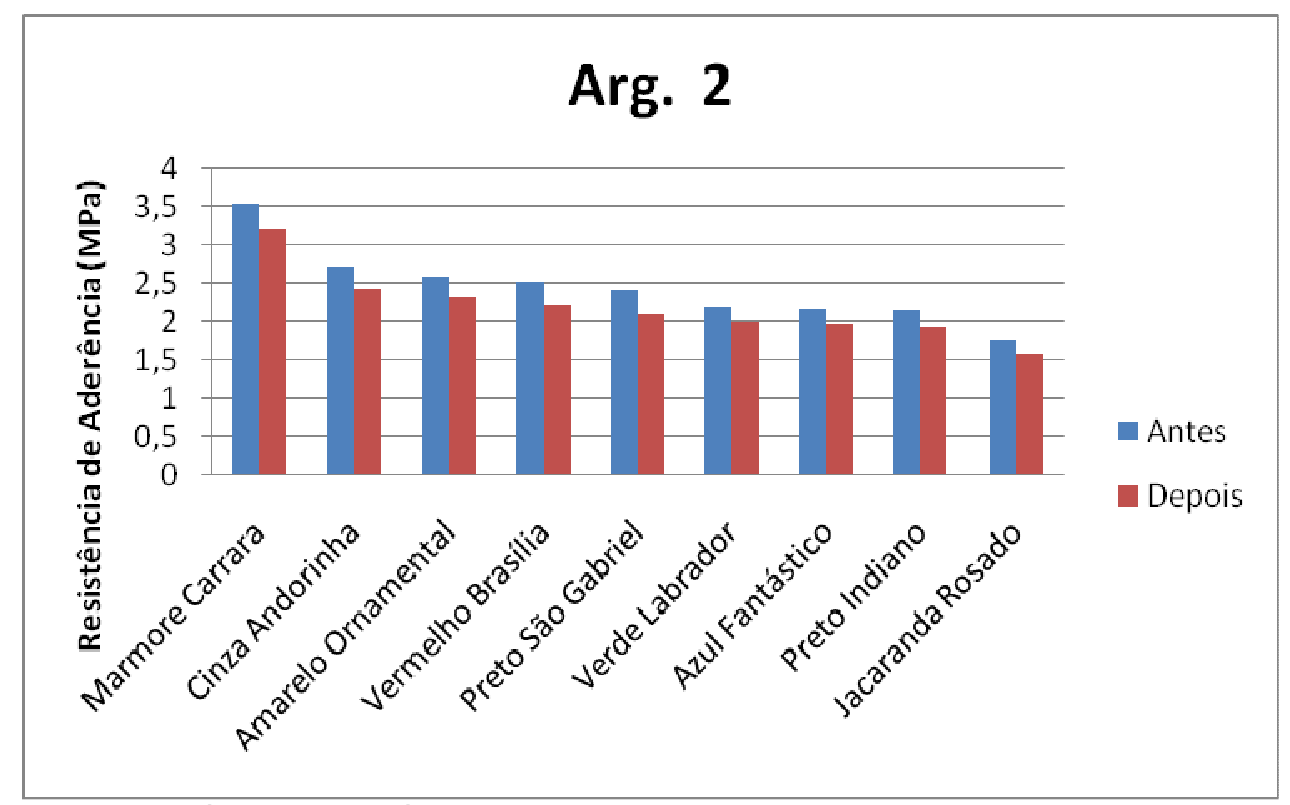

Figura 6.19 - Resistência de aderência da Arg2 antes e depois do ensaio de congelamento/degelo.

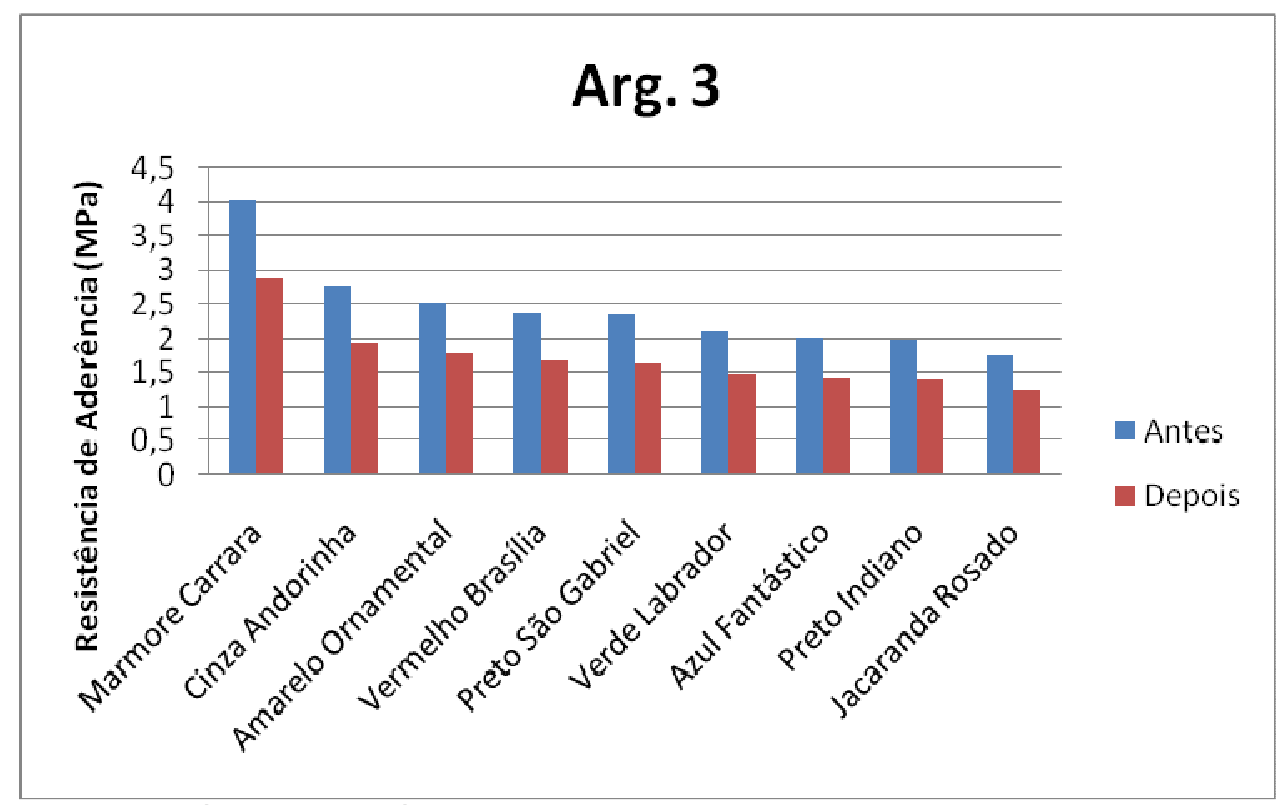

Figura 6.20 - Resistência de aderência da Arg3 antes e depois do ensaio de congelamento/degelo. 


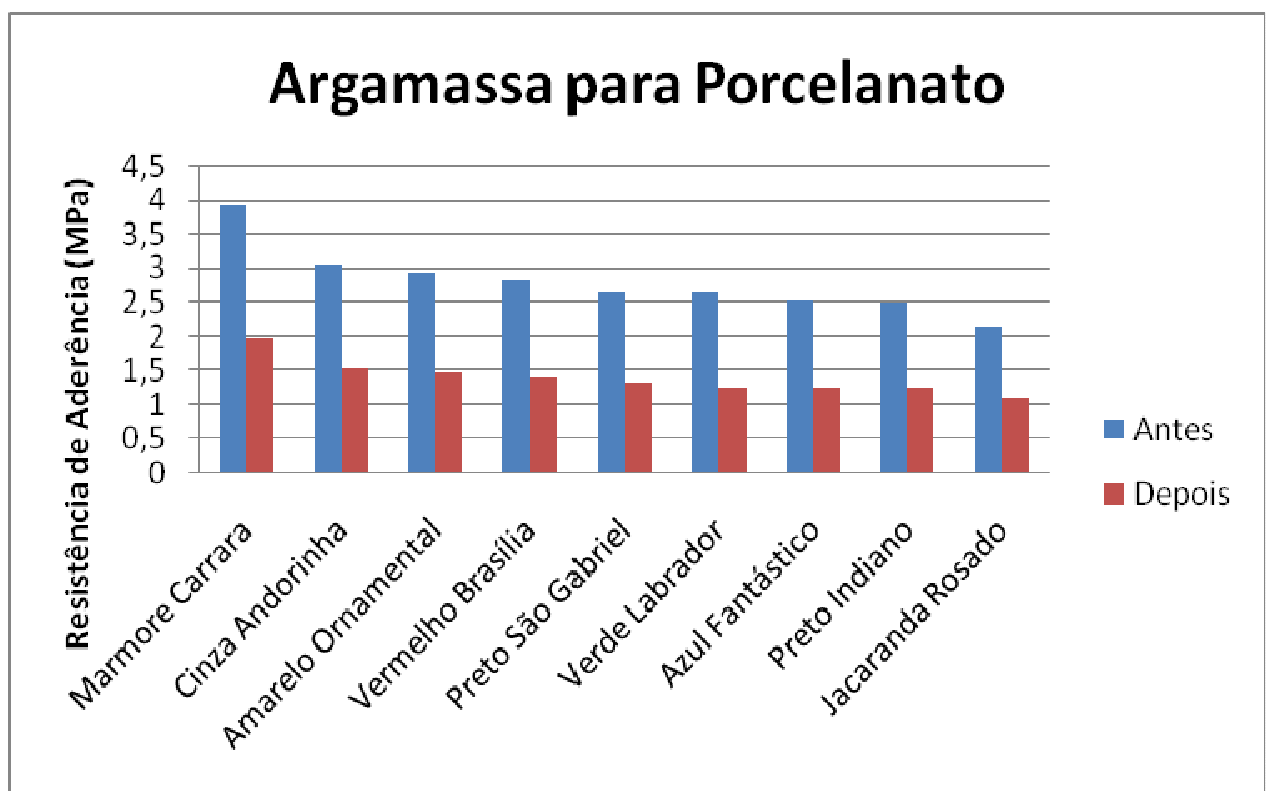

Figura 6.21 - Resistência de aderência da argamassa para porcelanato antes e depois do ensaio de congelamento/degelo.

A Figura 6.22 que reúne os valores da aderência após o congelamento/degelo das argamassas e rochas estudadas, mostra que a Arg. 2 apresentou maior aderência após ensaio de congelamento/degelo para todas as rochas estudadas.

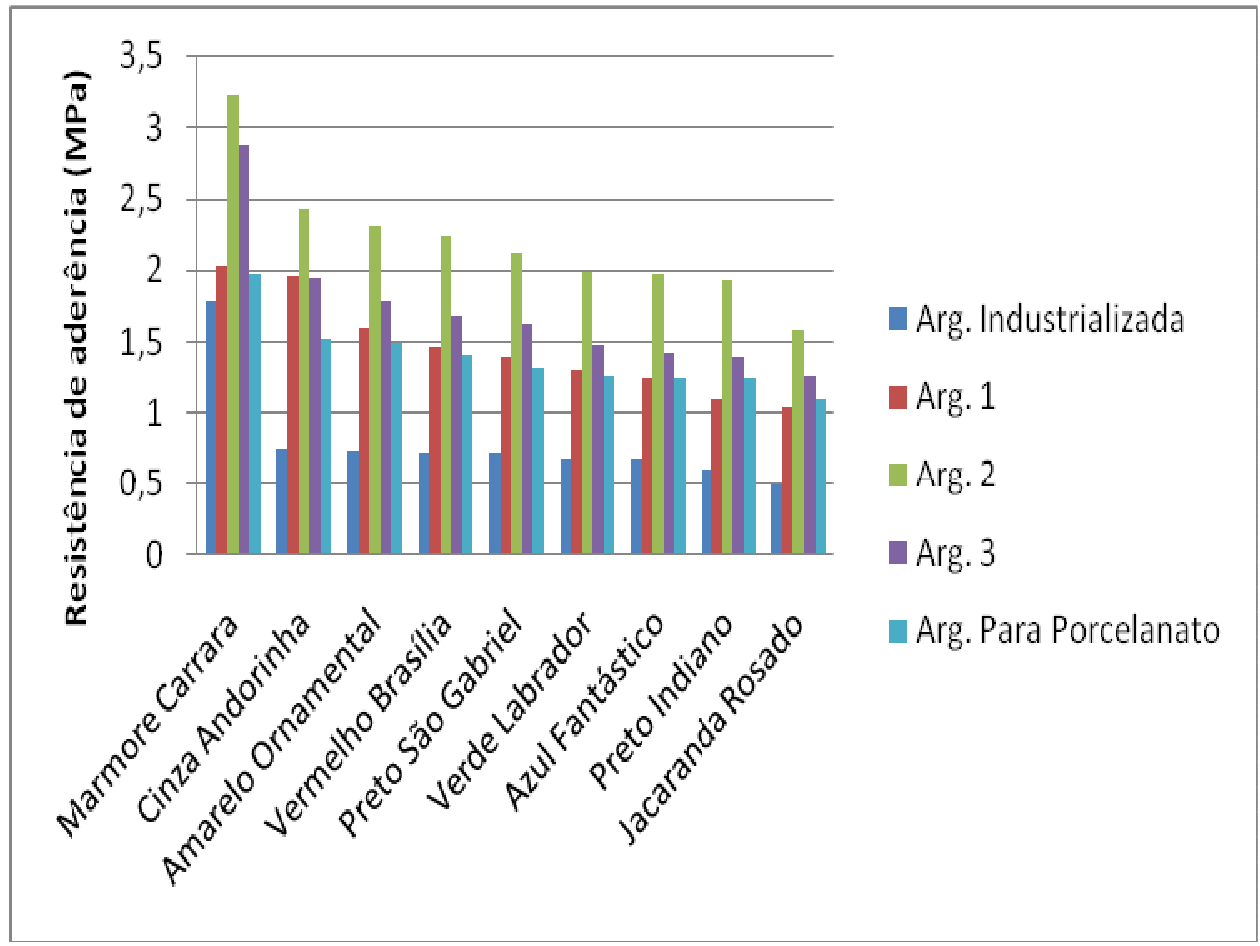

Figura 6.22 - Resistência de aderência das argamassas estudadas depois do ensaio de congelamento/degelo. 


\section{7- CONCLUSÕES}

- Todas as argamassas estudadas apresentaram tempo em aberto de acordo com a norma NBR 14083 (ABNT, 2004 - tempo em aberto - mínimo de 20 $\min )$;

- As argamassas preparadas em laboratório possuem maior flexibilidade que a industrializada, dentre elas a argamassa Arg3 é a mais flexível em estruturas com movimentações e neste é a mais indicada para evitar fissuras, trincas e desplacamentos;

- Todas as argamassas atenderam as especificações da norma NBR 14085 (ABNT, 2004) para o ensaio de deslizamento $(\leq 0,5 \mathrm{~mm})$. A Argamassa para Porcelanato apresentou o maior valor $(0,42 \mathrm{~mm})$ e sendo a mais fluida, é mais difícil de trabalhar quando utilizada na fixação de rochas em revestimentos verticais (fachadas). A argamassa $A R G 1$ apresentou o menor valor $(0,13$ $\mathrm{mm}$ ) por ser a argamassa com menor relação at/c, é de fácil manuseio tanto em superfícies horizontais (pisos) quanto em verticais (fachadas);

- Todas as argamassas apresentaram aderência superior a exigida por norma (1 $\mathrm{MPa}$ ) e dentre elas a Argamassa para Porcelanato apresentou maiores valores de aderência exceto para o mármore;

- A resistência de aderência dos "granitos" é influenciada pela rugosidade das superfícies das placas. Quanto maior a rugosidade maior a área da superfície de contato, maior será a aderência (ligamento físico - forças de Van der Walls), exceto para o mármore que apresentou alguma influência da rugosidade mas com aderências superiores a $4 \mathrm{MPa}$;

- A resistência de aderência é influenciada pela composição mineralógica. "Granitos" com maior quantidade de quartzo apresentaram menores valores de aderência;

- A resistência à aderência de monocristais de feldspatos é $50 \%$ maior em relação a monocristais de quartzo e 150\% menor em relação a monocristais de calcita quando fixados com a argamassa para porcelanato; 
- A microscopia óptica mostrou que não houve reações entre rocha/argamassa e nem penetração da argamassa na rocha (ancoragem);

- A resistência a aderência após o congelamento/degelo diminuiu para todas as argamassas, sendo que a Argamassa Arg2 apresentou menor decréscimo (aproximadamente 10\%).

\subsection{SUGESTÕES PARA TRABALHOS FUTUROS}

- Diferenças na composição mineralógica das rochas influenciaram nos valores de resistência de aderência necessitando estudos com outros tipos de rocha, em especial os mármores;

- Estudo detalhado da microestrutura do conjunto substrato padrão/argamassa/rocha utilizando outras técnicas além da microscopia óptica, como por exemplo, microscopia eletrônica de varredura, difração de Raios-X;

- Como foi constatada a variação da resistência de aderência após ciclos de congelamento e degelo é importante estudar a influência da temperatura no comportamento das argamassas colantes. 


\section{REFERÊNCIAS}

AKIAMA, S.Y; MEDEIROS, J.S.; SABBATINI, F.H. Flexibilidade de argamassa adesivas. In II SIMPOSIO BRASILEIRO DE TECNOLOGIA DAS ARGAMASSAS, Salvador, 1997. Anais. Salvador, 1997. P.233-245.

ALMEIDA, A. E. S. Estudo da influência das adições de sílica ativa e copolímeros estireno acrílico nas propriedades de argamassa para 0 assentamento de porcelanato.Tese de Doutorado. São Paulo. Departamento de arquitetura e urbanismo. Universidade de São Paulo. 2005.

AMERICAN SOCIETY FOR TESTING AND MATERIALS - ASTM C119/01. Standard terminology relating to dimension stone. 2001.

AMERICAN SOCIETY FOR TESTING AND MATERIALS - ASTM. C580-93. Standard Test method for flexural Strength and Modulus of elasticity of ChemicalResistant Mortars, Grouts, Monolithic Surfacings, and polymer Concretes. 1993.

AMERICAN CONCRETE INSTITUTE. State-of-the-Art Report on Polymer-Modified Concrete. ACI Committe 548. 3R-95, 1995.

ASSOCIAÇÃO BRASILEIRA DA INDUSTRIA DE ROCHAS ORNAMENTAIS ABIROCHAS. Balanço das exportações e importações brasileiras de rochas ornamentais e de revestimento no período janeiro-novembro de 2012 . Informe $\mathrm{n}^{\circ}$ 15/2012. 2012

ASSOCIAÇÃO BRASILEIRA DA INDUSTRIA DE ROCHAS ORNAMENTAIS ABIROCHAS. Rochas Ornamentais no Século XXI. Situação Brasileira. 2011a.

ASSOCIAÇÃO BRASILEIRA DA INDUSTRIA DE ROCHAS ORNAMENTAIS ABIROCHAS. Rochas Ornamentais no Século XXI. Cenário Mundial. 2011b. 
ASSOCIAÇÃO BRASILEIRA DA INDUSTRIA DE ROCHAS ORNAMENTAIS ABIROCHAS. Balanço das Exportações e Importações Brasileiras de Rochas Ornamentais e de Revestimento no período Janeiro-Outubro de 2011. Informe n¹3/2011. 2011.

ASSOCIAÇÃO BRASILEIRA DA INDUSTRIA DE ROCHAS ORNAMENTAIS ABIROCHAS. Balanço da produção mundial e do comércio internacional de rochas ornamentais em 2011. Informe $n^{\circ 11 / 201 .} 2012$.

ASSOCIAÇÃO BRASILEIRA DE NORMAS TÉCNICAS - ABNT (1992a). NBR 12042. Materiais Inorgânicos: Determinação do Desgaste por Abrasão. Rio de Janeiro. 3p.

ASSOCIAÇÃO BRASILEIRA DE NORMAS TÉCNICAS - ABNT (1992b). NBR 12763. Rochas para Revestimento: Determinação da Resistência à Flexão. Rio de Janeiro. $3 p$.

ASSOCIAÇÃO BRASILEIRA DE NORMAS TÉCNICAS - ABNT (1992C). NBR 12764. Rochas para Revestimento: Determinação da Resistência ao Impacto de Corpo Duro. Rio de Janeiro. 3p.

ASSOCIAÇÃO BRASILEIRA DE NORMAS TÉCNICAS - ABNT (1992d). NBR 12765. Rochas para Revestimento: Determinação do Coeficiente de Dilatação Térmica Linear. Rio de Janeiro. 3p.

ASSOCIAÇÃO BRASILEIRA DE NORMAS TÉCNICAS - ABNT (1992e). NBR 12766. Rochas para Revestimento: Determinação da Massa Específica Seca Aparente, Porosidade Aparente e Absorção d'água Aparente. Rio de Janeiro. 2p.

ASSOCIAÇÃO BRASILEIRA DE NORMAS TÉCNICAS - ABNT (1992f). NBR 12767. Rochas para Revestimento: Determinação da Resistência à Compressão Uniaxial. Rio de Janeiro. 2p. 
ASSOCIAÇÃO BRASILEIRA DE NORMAS TÉCNICAS - ABNT (1997a). NBR 13818. Placas Cerâmicas para Revestimento - Especificação e Métodos de Ensaios. Anexo E - Determinação da Resistência à Abrasão Profunda . Rio de Janeiro. 3p.

ASSOCIAÇÃO BRASILEIRA DE NORMAS TÉCNICAS - ABNT (1997b). NBR 13818. Placas Cerâmicas para Revestimento - Especificação e Métodos de Ensaios. Anexo $\mathrm{N}$ - Determinação do Coeficiente de Atrito. Rio de Janeiro. 2p.

ASSOCIAÇÃO BRASILEIRA DE NORMAS TÉCNICAS - ABNT (2004a). NBR 14081 - Argamassa colante industrializada para assentamento de placas de cerâmica: Especificação, 2004.

ASSOCIAÇÃO BRASILEIRA DE NORMAS TÉCNICAS - ABNT (2004b). NBR 14082 - Argamassa colante industrializada para assentamento de placas de cerâmica: Execução do substrato padrão e aplicação de argamassa para ensaio.

ASSOCIAÇÃO BRASILEIRA DE NORMAS TÉCNICAS - ABNT (2004c). NBR 14083 - Argamassa colante industrializada para assentamento de placas de cerâmica: Determinação do tempo em aberto.

ASSOCIAÇÃO BRASILEIRA DE NORMAS TÉCNICAS - ABNT (2004d). NBR 14084 - Argamassa colante industrializada para assentamento de placas de cerâmica: Determinação da resistência de aderência.

ASSOCIAÇÃO BRASILEIRA DE NORMAS TÉCNICAS - ABNT (2004e). NBR 14085 - Argamassa colante industrializada para assentamento de placas de cerâmica: Determinação do deslizamento.

ASSOCIAÇÃO BRASILEIRA DE NORMAS TÉCNICAS - ABNT (2003). NBR 15012: Terminologias de rochas ornamentais e de Revestimento. Rio de Janeiro.

AITCIN, PIERRE-CLAUDE. Concreto de Alto Desempenho. São Paulo, PINI,2000. 
BRANDÃO, W., SARDDOU FILHO, R., QUEIROZ, E.T.(1991). Mármores, Granitos e Outras Rochas Ornamentais no Brasil. In: SCHOBBENHAUS, C., QUEIROZ, E.T., COELHO, C.E.S. (edit.). Principais Depósitos Minerais do Brasil. Brasília. D.N.P.M. v. IV. Parte A. p.371-372.

BORTOLETTO, M. P. Avaliação das argamassas colantes industrializadas, tipo ACIII, para utilização no assentamento de revestimento cerâmico em fachadas de edifícios. Dissertação de mestrado do Departamento de Arquitetura da Escola de engenharia de São Carlos, da Universidade de São Paulo (2004).

CHIODI FILHO, C. Balanço das exportações e importações de rochas ornamentais e de revestimento em 2012. São Paulo: ABIROCHAS. Informe 01/2013. 17p. 2013.

COLLEPARDI, M. Admixtures used to enhance placing characteristics of concrete. Cement and Concrete Composites 20, pp. 103 - 112, 1998.

EUROPEAN COMITEE FOR STANDARDIZATION - CEN (2000) EN 12407. Natural Stone Test Methods - Petrograhic Examination.

FIORITO, A. J. S. I. Manual de argamassas e revestimentos: estudos e procedimentos de execução. Pini, 1994.

FRASCÁ, M.H..B.O. \& QUITETE, E.B. Rochas Ornamentais do Estado de São Paulo - Características Tecnológicas. Rochas de Qualidade. №154. p.154-171, 2000.

FRASCÁ, M.H.B.O. Estudos Experimentais de Alteração Acelerada de Rochas Graníticas para Revestimento. Tese de Doutorado. São Paulo. Instituto de Geociências. Universidade de São Paulo. 281p, 2003.

FRAZÃO, E.B. \& PARAGUASSU, A.B. Materiais Rochosos para Construção. In: OLIVEIRA, A.M.S.O. \& BRITO, S.N.A. (eds.). Geologia de Engenharia. São Paulo. 
Associação Brasileira de Geologia de Engenharia - ABGE, CNPq/FAPESP. P. 331342, 1998.

FRAZÃO, E.B. Catálogo das Rochas Ornamentais do Estado do Espírito Santo. São Paulo: Instituto de Pesquisas Tecnológicas (IPT - Publicação 2048). 77p, 1993.

FRAZÃO, E. B. Tecnologia de Rochas na Construção Civil. Associação Brasileira de Geologia de Engenharia e Ambiental. 2002.

GOLDENSTEIN, H. Microscopia óptica. Disponível em: http://www.angelfire.com/.../1_multipart_xF8FF_6_Microscopia_otica.pdf>. Acesso em 16/12/2011 às $14: 00 \mathrm{~h}$

GRASSELLI, G. Shear Strenght of Rock Joints on Quantified Surface Description. Tese de Doutorado. Lausanne. Escole Polytechnique Federal de Lausanne, 2001.

GROOT, C. J. W. P. Aspects of mortar-brick bond. In: INTERNATIONAL BRICK AND BLOCK MASONRY CONFERENCE, $8^{\text {TH }}$, dublin, sept.19-21, Proceedings. London, Elsevier, v.1, 1988.

International Organization for Standardization - ISO 13007 - 2. Ceramic tiles Grouts and adhesives - Part 2: test methods for adhesives. 2010.

KHAYAT, K. H.; AÏTCIN, P. C. Silica fume in concrete: an overview. In: FLY ASH, SILICA FUME, SLAG, AND NATURAL POZZOLANS IN CONCRETE. Proceedings Fouth International Conference, Instanbul, Turkey. Volume II. ACI, SP - 132, 1992.

LAVELLE, J. Acrylic latex-modified portland cement. ACI Materials Journal, vol 85, $\mathrm{n}^{\circ} 1$, jan/feb, 1988.

MALHOTRA, V. M. Et al. Role of sílica fume in cocrete. In: Advances in concrete technology. Proceedings: CANMET, p. 925-991, 1992.

MEDEIROS, J. S. Tecnologia e projeto de revestimentos cerâmicos de fachadas de 
edifícios, Tese de doutorado da Escola Politécnica da Universidade de São Paulo. Jun de 1999.

MEHTA, P. K.; MONTEIRO, P. J. M. CONCRETO: Estrutura, propriedades e materiais.

MORAES, M. C.; RODRIGUES, E. P. Exemplo de aplicação de coloração seletiva de feldspato potássio e cálcicos, como técnica auxiliar no estudo de rochas. In: $21^{\circ}$ Congresso Brasileiro de Cerâmica, 1977, Blumenau.

NEVILLE, A. M. Propriedades do Concreto. PINI $1^{\text {a }}$ Edição

NOGAMI, L. Fixação de placas de rochas ornamentais: Estudo da aderência com argamassa colante. Dissertação de mestrado do programa de pós Graduação em Geotecnia da Escola de Engenharia de São Carlos, Universidade de São Paulo. 2007.

O guia weber, Weber.col - mármores e granites externo, 2013. Site: http://www.weber.com.br/assentar-revestimentos/o-guia-weber/produtos/pedrasassentamento-de-marmores-granitos-ardosias-miracema-sao-tome-mineira-egoias/webercol-marmores-e-granitos-externo.html

OHAMA, Y. Recent progress in concrete-polymer composites. Advanced Cement Based Materials, 5, p. $31-40,1997$.

PARAGUASSÚ, A. B.; RODRIGUES, J. E.; RIBEIRO, R. P. Medidas de Rugosidade em Chapas de Granitos Ornamentais Serrados em Teares Multilâminas. In: XLII CONGRESSO BRASILEIRO DE GEOLOGIA, 2004, Araxá-MG. XLII Congresso Brasileiro de Geologia. 2004.

PEREZ, F. (2003). Argamassas colantes utilizadas na Fixação de Revestimento Cerâmicos, Dissertação de Mestrado do programa de Pós Graduação em Ciências e Engenharia de Materiais, da Universidade de São Paulo. 
PINTO, R. C. A.; HOVER, K. Superplasticizer and Sílica Fume Addition Effects on Heat of Hydration of Mortar Mixtures with Low Water-Cementitious Materials Ration. American Concrete Institute. Materials Journal, vol. 96 n 5, sep-oct., 1999.

RENGERS, N. Influence of roughness on the friction properties of rock planes. Congress Internacional Society of Rock Mechanics, 1970.

RIBEIRO, R. P. Influência das características petrográficas de granitos no processo industrial de desdobramento de blocos, Tese de Doutorado do programa de Pós graduação em Geotecnia, da Escola de Engenharia de São Carlos, da Universidade de São Paulo, 2005.

RIUNNO, V.; MURELLI, P. Cuan flexible son los morteros "flexible"? In: CONGRESSO MUNDIAL DE LA CALIDAD DEL AZULEJO Y DEL PAVIMENTO CERAMICO, 2, Castellón. Qualicer, p. 475-493, 1992.

SILVEIRA, L.L.L. Estudo Comparativo de Granitos Ornamentais Brasileiros no Processo de Polimento Industrial. Tese de Doutorado. São Carlos. Escola de Engenharia de São Carlos da Universidade de São Paulo, 2007.

SOSSAI, F. J. M. CARACTERIZAÇÃO DE ROCHAS PARA USO NA CONSTRUÇÃO CIVIL. Dissertação de mestrado do programa de Pós-Graduação em Geotecnia, da Universidade Federal de Viçosa. 2006

SPÍNOLA, S.V.P.A.C. Influência da Qualidade da Serragem de Granitos no Consumo Energético do Desbaste. Dissertação de mestrado. Lisboa. Instituto Superior Técnico. Universidade Técnica de Lisboa. 138p, 1998.

ULRICH, H. Introduction to industrial polymers. 2 Ed. Hanser Publishers, 1993.

UNION EUROPEEN POUR L'AGREMENT TECHNIQUE DANS LA CONSTRUCTION - UEAtc. Technician guide for the assessment of ceramic tile adhesive. Paris. 1990. 
WALTERS, D. G. What are latexes? Concrete International: Design \& Construction. Vol 9, n¹2, dez, pp. 44-47, 1987.

YOSOMIYA, R. Et al. Adhesion and bonding in composites. Marchel Dekker, Inc, 1990. 